The University of Chicago Law Review, Vol. 69, pp. 751-846 (2002)

\title{
Managerial Power and Rent Extraction in the Design of Executive Compensation
}

\author{
Lucian Arye Bebchuk $\dagger$ \\ Jesse M. Fried $\dagger \dagger$ \\ David I. Walker $\dagger \dagger \dagger$
}

This Article develops an account of the role and significance of managerial power and rent extraction in executive compensation. Under the optimal contracting approach to executive compensation, which has dominated academic research on the subject, pay arrangements are set by a board of directors that aims to maximize shareholder value. In contrast, the managerial power approach suggests that boards do not operate at arm's length in devising executive compensation arrangements; rather, executives have power to influence their own pay, and they use that power to extract rents. Furthermore, the desire to camouflage rent extraction might lead to the use of inefficient pay arrangements that provide suboptimal incentives and thereby hurt shareholder value. The authors show that the processes that produce compensation arrangements, and the various market forces and constraints that act on these processes, leave managers with considerable power to shape their own pay arrangements. Examining the large body of empirical work on executive compensation, the authors show that managerial power and the desire to camouflage rents can explain significant features of the executive compensation landscape, including ones that have long been viewed as puzzling or problematic from the optimal contracting perspective. The authors conclude that the role managerial power plays in the design of executive compensation is significant and should be taken into account in any examination of executive pay arrangements or of corporate governance generally.

\footnotetext{
$\dagger \quad$ William J. Friedman and Alicia Townsend Friedman Professor of Law, Economics, and Finance, Harvard Law School; Research Associate, National Bureau of Economic Research.

$\dagger \dagger \quad$ Acting Professor of Law, Boalt Hall School of Law, University of California, Berkeley.

$\dagger \dagger \dagger$ Associate, Ropes \& Gray, Boston, Massachusetts; John M. Olin Research Fellow in Law, Economics and Business, Harvard Law School, 1999-2000.

A substantially different version of this Article was circulated earlier under the title "Executive Compensation in America: Optimal Contracting or Extraction of Rents?" We have benefited from the valuable suggestions of various individuals, including Franklin Ballotti, Lisa Bernstein, Victor Brudney, Brian Cheffins, Steve Choi, Mel Eisenberg, Charles Elson, Allen Ferrell, Jeff Gordon, Assaf Hamdani, Sharon Hannes, Henry Hansmann, Marcel Kahan, Louis Kaplow, Reinier Kraakman, Michael Levine, Saul Levmore, Kevin Murphy, Richard Painter, Mark Roe, David Schizer, Steve Shavell, Eric Talley, Randall Thomas, Detlev Vagts, Michael Wachter, Ivo Welch, David Yermack and participants in two Harvard seminars, the American Association of Law Schools Business Law Panel on Executive Compensation, and the University of Chicago Law Review Symposium on Management and Control of the Modern Business Corporation. Nicholas Hecker, Matthew Heyn, Ryan Kantor, Jason Knott, Matthew McDermott, and Selena Medlen provided excellent research assistance. For financial support, we wish to thank the John M. Olin Center for Law, Economics, and Business at Harvard Law School, the Berkeley Committee on Research, and the Boalt Hall Fund.
} 


\section{TABLE OF CONTENTS}

Introduction 753

I. The Optimal Contracting Approach and Its Limitations..........761

A. The Optimal Contracting Approach ................................761

B. The Limitations of the Optimal Contracting Approach....764

II. The Managerial Power Approach .........................................783

A. Managerial Power and the Extraction of Rents ............... 784

B. "Outrage" Costs and Constraints .....................................786

C. The Critical Role of "Camouflage" ..................................788

D. Compensation Consultants and Camouflage .....................789

E. The Design of Stock Option Plans: The Devil Is in the Details ....................................................................... 791

F. A Note on Conforming to Norms ...................................793

III. Evidence Better Explained by the Managerial Power Approach

A. Rewarding Executives for General Market Rises.............796

B. Near-Uniform Use of At-the-Money Options...................817

C. Resetting of Option Exercise Prices ..................................821

D. Executives' Broad Freedom to Unwind Incentives ..........825

E. Reload Options .............................................................. 831

F. Gratuitous Acquisition-Related Payments .......................834

G. Differences between Executives with More and

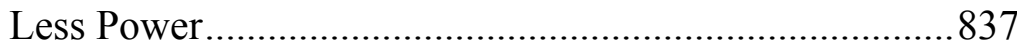

H. Differences between U.S. and Non-U.S. Companies .......842 


\section{INTRODUCTION}

Executive compensation has long attracted a great deal of attention from academics, the media, Congress, and the public at large. During the extended bull market of the 1990s, stock option programs adopted by public companies yielded unprecedented gains for senior executives. These gains were accompanied by a parallel rise in academic work on the subject. ${ }^{2}$ Indeed, it appears that the rate of growth in such academic work has outpaced even the growth rate of executive compensation. ${ }^{3}$

This Article questions the dominant approach in the academic work on executive compensation. It also seeks to put forward a systematic and comprehensive account of an alternative approach to the study of executive compensation - the "managerial power approach"- that focuses on the role of managerial power in shaping executive compensation practices. The substantial influence of managerial power on executive compensation, we argue, is suggested both by a realistic analysis of the processes that produce executive pay and by an examination of the substantial body of empirical evidence on the subject.

The dominant approach to the study of executive compensation among academics has for some time been what we call "the optimal contracting approach." " Under this approach, executive compensation practices in large, publicly traded companies are viewed as designed to minimize the agency costs that exist between senior executives (the agents) and shareholders (the principals). The board is viewed as seeking to maximize shareholder value, with the compensation scheme be-

\footnotetext{
1 The median compensation of S\&P 500 CEOs increased by approximately 150 percent from 1992 to 1998, and option-based compensation provided the largest share of the gains. See Tod Perry and Marc Zenner, CEO Compensation in the 1990s: Shareholder Alignment or Shareholder Expropriation?, 35 Wake Forest L Rev 123, 145 (2000).

2 Recent surveys of this voluminous literature include Perry and Zenner, 35 Wake Forest L Rev 123 (cited in note 1); John M. Abowd and David S. Kaplan, Executive Compensation: Six Questions that Need Answering, 13 J Econ Perspectives 145 (1999); and Kevin J. Murphy, Executive Compensation, in Orley Ashenfelter and David Card, eds, Handbook of Labor Economics 2485 (Elsevier 1999). A noteworthy survey from an earlier era is Michael C. Jensen and Jerold L. Zimmerman, Management Compensation and the Managerial Labor Market, 7 J Acct \& Econ 3 (1985).

3 See Murphy, Executive Compensation at 2487 (cited in note 2). He demonstrates graphically that the increase in academic papers on the subject of CEO pay outpaced the increase in total CEO pay during the late 1980s and early 1990 s.

4 This is the leading view among financial economists, who have done most of the scholarship in this area. Indeed, as we discuss later in the Article, there is a large body of work in financial economics that seeks to come up with an explanation, within an optimal contracting framework, for almost every feature of the executive compensation landscape. The optimal contracting view is also taken by an important line of legal scholarship. See, for example, Frank H. Easterbrook, Managers' Discretion and Investors' Welfare: Theories and Evidence, 9 Del J Corp L 540 (1984); Daniel R. Fischel, The Corporate Governance Movement, 35 Vand L Rev 1259 (1982); Nicholas Wolfson, A Critique of Corporate Law, 34 U Miami L Rev 959 (1980); Robert Thomas, Is Corporate Executive Compensation Excessive?, in M. Bruce Johnson, ed, The Attack on Corporate America 276 (McGraw Hill 1978).
} 
ing designed to serve this objective. Financial economists, both theorists and empiricists, have largely worked within this model in attempting to explain the various features of executive compensation arrangements as well as the cross-sectional variation in compensation practices among firms.

We seek to contrast this optimal contracting approach to the study of executive compensation with an approach that we label "the managerial power approach." Analysis from this perspective focuses on the ability of executives to influence their own compensation schemes. According to the considered approach, compensation arrangements approved by boards often deviate from optimal contracting because directors are captured or subject to influence by management, sympathetic to management, or simply ineffectual in overseeing compensation. As a result of such deviations from optimal contracting, executives can receive pay in excess of the level that would be optimal for shareholders; this excess pay constitutes rents..$^{5}$ More importantly, to camouflage or facilitate the extraction of rents, managerial power can lead to the use of inefficient pay structures that weaken or distort incentives and that thus, in turn, further reduce shareholder value. Although recognition of the role of managerial power lies at the heart of much of the public criticism of compensation levels and practices, this role has attracted relatively little attention and analysis in the academic literature.

5 Executives can extract rents in ways other than through their executive compensation arrangements. See, for example, Lucian A. Bebchuk and Christine Jolls, Managerial Value Diversion and Shareholder Wealth, 15 J L, Econ, \& Org 487, 487-90 (1999) (analyzing the costs of permitting managers to extract value other than through their formal compensation arrangements); Jesse M. Fried, Reducing the Profitability of Corporate Insider Trading through Pretrading Disclosure, 71 S Cal L Rev 303, 348-64 (1998) (explaining how corporate insiders continue to be able under existing rules to make profits from trading on inside information); Jesse M. Fried, Insider Signaling and Insider Trading with Repurchase Tender Offers, 67 U Chi L Rev 421, 453-70 (2000) (showing that managers are likely to use repurchase tender offers to engage in insider trading). It would be possible, of course, to define compensation schemes as including benefits that managers obtain in any way as a result of their position, including benefits from insider trading, the taking of corporate opportunities, and so forth. In this Article, however, our focus is solely on the benefits that executives get and the rents they extract from arrangements that are formally defined and ordinarily viewed as compensation.

6 Many practitioners, investors, shareholder activists, and media commentators have expressed views that are close to the view we put forward more systematically in this work. See, for example, Graef S. Crystal, In Search of Excess (Norton 1991); Shawn Tully, Raising the Bar, Fortune 272 (June 8, 1998) (reporting some of Warren Buffett's views on executive compensation); Robert A.G. Monks and Nell Minow, Corporate Governance, 221-25 (2d ed Blackwell Business 2001).

Although academics commonly hold what we have called the "optimal contracting" view, see note 4, there is some academic work that is close in spirit to ours. A number of legal scholars have been skeptical about claims that executive compensation arrangements are designed to maximize shareholder value. See, for example, Linda J. Barris, The Overcompensation Problem: A Collective Approach to Controlling Executive Pay, 68 Ind L J 59 (1992); Mark J. Loewenstein, Reflections on Executive Compensation and a Modest Proposal for (Further) Reform, 50 SMU L Rev 201 (1996); Detlev Vagts, Challenges to Executive Compensation: For the Markets or the Courts?, 8 J Corp L 231 (1983); Carl T. Bogus, Excessive Executive Compen- 
Although the managerial power approach is conceptually quite different from the optimal contracting approach, the former is not proposed as a complete replacement for the latter. One can take the view that compensation arrangements are shaped both by managerial power and by what would be optimal. The managerial power approach merely implies that compensation practices cannot be adequately explained by optimal contracting alone. Rather, practices might be adopted that deviate significantly from those suggested by optimal contracting. Under the managerial power approach, compensation practices can be fully understood only with careful attention to the role of managerial power.

Our analysis indicates that managerial power and rent extraction are indeed likely to play a significant role in executive compensation in the United States. At the level of theory, we argue that a realistic analysis of the compensation-setting process indicates that its outcomes are likely to be much influenced by managerial power and by managers' interest in extracting rents. As an empirical matter, we argue that the extensive empirical evidence on executive compensation is consistent with the predictions of the managerial power approach. Indeed, this approach can better explain certain significant features of the executive compensation landscape, including ones that have been long regarded as puzzling.

Part I begins by providing an account of the standard optimal contracting approach, and it then provides a detailed analysis of the limitations and shortcomings of this approach. Optimal compensation contracts could result from effective arm's length bargaining between the board and the executives, from market constraints that induce players to adopt such contracts even in the absence of arm's length bargaining, or from shareholders' ability to directly shape executive compensation arrangements. Our analysis indicates that none of these forces can be expected to constrain executive compensation effectively. Bargaining with the board is in fact far from arm's length. Market forces are not sufficiently strong and fine-tuned to eliminate substantial deviations from optimal contracting. And shareholders have little practical ability to prevent such deviations.

After analyzing the shortcomings of the optimal contracting approach, we turn in Part II to providing an account of the managerial

sation and the Failure of Corporate Democracy, 41 Buff L Rev 1 (1993); Charles M. Yablon, Bonus Questions-Executive Compensation in the Era of Pay for Performance, 75 Notre Dame L Rev 271 (1999). And several empirical papers by financial economists have recently suggested that some of their findings are consistent with, or indicative of, "appropriation" or "skimming" by executives. Part III discusses such studies by Bertrand and Mullainathan; Benz, Kucher, and Stutzer; Blanchard, Lopez-de-Silanes, and Shleifer; and Yermack. No work, however, has thus far attempted to put forward a full account of a managerial power approach-including both a theoretical framework for such an approach and an examination using this approach of the large body of empirical evidence on executive compensation - as we aim to do in this Article. 
power approach. The very reasons for questioning optimal contracting's ability to explain adequately compensation practices also suggest that executives will have substantial influence over their own pay. These reasons also suggest that the greater managers' power, the greater their ability to influence pay and to extract rents.

One important building block of the managerial power approach is that of "outrage" costs and constraints. That executives can exert influence on their pay does not imply that there are no constraints on their ability to do so. Although the need for board approval and the presence of market forces cannot be expected to produce compensation arrangements consistent with optimal contracting, they can and commonly do provide some constraints. The tightness of these constraints depends, in part, on the outrage that a particular compensation arrangement is expected to generate. Outrage can be costly to directors and managers by causing embarrassment or reputational harm, as well as by reducing the willingness of shareholders to support incumbents in control contests. The more outrage a compensation arrangement is expected to generate, the more reluctant directors will be to approve the arrangement, and the more hesitant managers will be to propose it in the first instance. Thus, whether a compensation arrangement that is favorable to executives but suboptimal for shareholders is adopted will depend on how the arrangement is perceived by outsiders and, in particular, on how much outrage (if any) it is expected to produce.

The potential significance of outrage costs explains the importance of "camouflage," yet another building block of the managerial power approach. Because outrage resulting from outsiders' recognition of the presence of rent extraction provides a possible check on managers' power to extract rent, managers have an incentive to obscure and legitimize - or, more generally, to camouflage - their extraction of rents. Indeed, the extensive use of compensation consultants, which might be viewed as an attempt to optimize incentives under the optimal contracting approach, can itself be seen as a means of justifying and legitimizing pay under the managerial power approach. This concept of camouflage will turn out to be quite useful in explaining many of the patterns and puzzles provided by the executive compensation landscape.

The desire to camouflage might lead to the adoption of inefficient compensation structures that, compared with optimal contracting arrangements, fail to provide desirable incentives, or even supply perverse incentives. In our view, the reduction in shareholder value caused by these inefficiencies, rather than the excess rent captured by managers, might well be the biggest cost arising from the influence of managerial power on compensation practices. Thus, improvement in this area may 
provide considerable benefits to shareholders from better managerial incentives and performance.

Part III identifies and discusses a significant number of compensation practices and patterns that can be explained by the managerial power approach and that suggest that managerial power influences pay. Some of the practices and features that we analyze in this Part are ones that have long been regarded as puzzles by researchers working within the optimal contracting approach.

We first turn to firms' failure to use option schemes that filter out stock price rises that are due largely to industry and general market trends and thus are unrelated to the managers' performance. Such filtering could be done by using what we call "reduced-windfall" optionsoptions designed to reduce executives' ability to make gains unrelated to their managerial performance. Such options could be designed using indexing, benchmarking, or some other feature that has a similar effect.

When option compensation is based on changes in the absolute share price, even poorly performing managers might make significant profits. The substantial compensation dollars that are currently spent on rewarding managers for general market rises could be either used to enhance incentives (by, for example, giving managers a larger number of reduced-windfall options) or saved. As we show, the almost complete absence of any form of reduced-windfall options is rather difficult to explain from an optimal contracting approach. We explore a number of alternative ways to filter out general market and sector rises, and we show how unlikely it is that not using any form of filtering is generally optimal.

The absence of any filtering of general market or industry effects is not puzzling, however, under the managerial power approach. Under this approach, compensation schemes are designed with an eye to benefiting executives while reducing outrage costs by staying within the range of legitimacy and acceptability. Given that the use of conventional options is well established and generally considered a legitimate form of compensation, and that indexing or benchmarking is likely to be costly or inconvenient for managers, the lack of any real movement toward reduced-windfall options is consistent with the managerial power approach.

Part III next considers the nearly uniform use of at-the-money options. An optimally designed option scheme would seek to provide riskaverse managers with the strongest cost-effective incentives to exert effort and make value-maximizing decisions. The optimal exercise price under such a scheme should depend on a multitude of factors that are likely to vary from executive to executive, from company to company, 
and from time to time. Such factors might include the degree of managerial risk aversion (which in turn might be affected by the manager's age and wealth), the project choices available to the company, the volatility of the company's stock, the expected rate of inflation, and the length of the executive's contract, among other things. There is no reason to expect that the same exercise price formula would be optimal for all executives at all firms in all industries at all times. The fact that options are almost uniformly issued at-the-money is thus rather difficult to explain from an optimal contracting perspective.

The uniform use of at-the-money options is not puzzling, however, when examined under the managerial power approach. Given that executives benefit from lower exercise prices, there will be a desire to push exercise prices as far down as is possible without generating too much outrage. There is thus little reason for designers of plans to award out-of-the-money options - that is, to raise the exercise prices above the market price at the time the options are issued-given that some justification is available for at-the-money options. On the other hand, in-themoney options might be regarded as a windfall and thereby generate outrage costs. Furthermore, the grant of in-the-money options would trigger a charge to accounting earnings, and this might undermine one of the excuses for not using reduced-windfall options - that the use of such options would give rise to an accounting charge. Because in-the-money options might thus be difficult or costly for managers to obtain, and atthe-money options are the ones most favorable to managers within the remaining range of possibilities, a uniform use of at-the-money options is quite consistent with the managerial power approach.

Another problem for the optimal contracting approach - and one that has been little noticed by researchers despite its importance- concerns managers' widespread freedom to undo the financial incentives provided to them by their compensation arrangements. Under optimal contracting, when value is spent on providing managers with incentives, it might well be desirable to place substantial limits on managers' freedom to unwind them. But existing practice fails to do so.

Stock options generally vest only after a specified period, which ensures that the executive cannot walk out with the underlying shares without first serving the company for the specified period. Although an executive becomes entitled to the awarded options once their vesting period is over, the compensation contract could preclude the executive from "cashing out" the vested options - that is, from exercising the options and then selling the acquired shares. Such a limitation would maintain incentives for an additional period and thus avoid the need to grant new options to replace the ones that have been cashed out. There 
is no reason to expect that optimal contracts would generally make the vesting date and the cash-out date the same. Yet, the two dates are almost always the same.

An optimal contract also might prohibit managers receiving an option grant from weakening (if not eliminating) the incentive effects of the option grant by selling an equivalent number of shares they already own. Standard practice fails to do so, however, and executives receiving new options often respond by heavily selling already-owned shares. Contracts generally also do not prohibit executives from hedging vested or even unvested options, and executives often hedge their exposure to the firm when disposal is either not possible or too costly from a tax perspective.

Furthermore, even if it were optimal in some cases to grant an executive broad freedom to cash out and unwind incentives in order to serve the executive's liquidity or diversification needs, there would be little reason to give the executive unrestricted control over the timing of stock sales. Liquidity and diversification needs hardly call for permitting the executive to cash out positions on any given day that the executive chooses. Although some firms use "trading windows," many firms place no limits on the freedom of executives to time the cashing out or hedging of their equity positions. The evidence indicates that executives' freedom to engage in such timing, coupled with inside information, enables executives to make substantial trading profits (at the expense of public shareholders).

The lack of restrictions on the amount and timing of stock selling, while difficult to explain from an optimal contracting perspective, is easily explained under the managerial power approach. Under this approach, the design of compensation plans is partly influenced by managerial power. Avoiding such restrictions on unwinding benefits managers and does so in a way that thus far has been largely under the radar screen.

Part III also examines the phenomena of option repricing and reloadable options. Repricing refers to the lowering of the options' strike price when the stock price falls below the original exercise price. The possibility that the exercise price will be lowered ex post if the stock price declines dilutes ex ante incentives. To be sure, such downward repricing can, in theory, be useful for retaining and providing incentives to good managers when the stock price falls for reasons beyond managers' control. However, indexing would also solve the incentive problem that arises when the market price falls much below the exercise price of the options due to a general market or sector decline. The lack of indexing on the upside and the use of repricing on the downside ensures that 
managers receive both the full value of stock price increases that are due to market or sector rises and protection against market and sector declines on the downside.

Reloadable option plans are plans under which an executive who exercises options pays the exercise price by handing over firm shares that he already owns, and receives a new option for each share tendered with the same expiration date as the old options being exercised. These plans allow executives to profit from share price volatility even if the long-term share performance is flat. The only possible justification that can be given for reloadable options is that - given executives' freedom to unwind incentives - it might be desirable to have a mechanism that will replenish those incentives. But this problem could have been, of course, more easily and effectively addressed by placing limits on executives' freedom to unwind incentives. The puzzling combination of freedom to unwind incentives and reloading options aimed to correct it, we argue, can best be explained under the managerial power approach.

Another significant practice examined by Part III is that of "gratuitous" acquisition-related payments. CEOs of acquired firms in many cases receive payments from their firm or the acquiring firm that are "gratuitous" in that they are not required under the terms of the CEO's compensation contract (including the golden parachute, if any). These payments take a number of different forms, including increases in the contractual golden parachute payout and separate cash payments. Such gratuitous payments, we show, are much more difficult to explain under the optimal contracting approach than under the managerial power approach.

Finally, and importantly, we show in Part III that the managerial power approach can help explain cross-company as well as crosscountry differences in executive pay. The managerial power approach predicts that managers will be paid more in firms in which they have relatively more power. This prediction, we show, is confirmed by empirical studies. Surveying the empirical literature on CEO compensation in the U.S., we find that pay is higher in firms where the CEO is more powerful vis-à-vis the board, in firms with antitakeover provisions that protect incumbents from hostile takeovers, in firms with a smaller institutional investor presence, and in firms where there is no large outside shareholder. We also explain how the managerial power approach can shed light on differences in pay between U.S. and non-U.S. companies.

The conclusion that managerial power and rent extraction play a significant role in executive compensation has important implications for the study, regulation, and practice of corporate governance. We plan to explore fully these implications in subsequent work. Here, however, 
we focus on a prior and important step: to put forward a systematic framework for the study of this subject and, furthermore, to show that the evidence supports the view that managerial power and rent extraction play an important role in executive compensation.

\section{The Optimal CONTRACTING APPROACH AND ITS Limitations}

Our analysis focuses on public companies that lack a controlling shareholder. Managers of these companies have substantial power and discretion but generally own only a small fraction of the firm's equity. The interests of the shareholder-principals and manager-agents are not perfectly convergent, and thus there exists an agency problem. The two approaches to the study of executive compensation that we discuss both start with the recognition that there is an agency problem, but they take that recognition in different directions. This Part discusses the approach that is more conventional among academics: that executive compensation arrangements can generally best be understood as instruments that the board uses in the shareholders' interest to address the agency problem.

Part I.A describes the optimal contracting approach to executive compensation. In Part I.B, we discuss the limitations and shortcomings of this approach. An optimal principal-agent contract would generally be chosen if (i) the board were bargaining with the executives at arm's length; (ii) the directors or executives were constrained by market forces from deviating from optimal compensation contracts; or (iii) shareholders could use the courts or another mechanism to force managers to adopt compensation contracts that maximize shareholder value. We argue in Part I.B that none of these propositions commonly holds, and thus there are reasons to doubt whether the optimal contracting approach can fully or even largely explain the executive compensation landscape.

\section{A. The Optimal Contracting Approach}

There is no contract that would perfectly align the interests of managers and shareholders. The optimal contract is therefore the one that minimizes agency costs (that is, the sum of contracting costs, monitoring costs, other costs incurred in achieving a certain level of compliance with the principal's interest) and the costs of the residual divergence.

7 In 1996, for example, CEOs of S\&P 500 manufacturing companies owned an average of fewer than 1 percent of their firms' shares, while median ownership was only 0.11 percent. See Murphy, Executive Compensation at 2490-93 (cited in note 2).

8 A thorough review of the optimal contracting literature is beyond the scope of this Article. Impor- 
Under the optimal contracting approach, this is exactly what executive compensation packages are designed to do. The board, attempting to maximize shareholder wealth, seeks to establish optimal incentives for the executives. This approach is captured in various formal models that view the board of directors as selecting an optimal compensation program for shareholders. As we will discuss, a great deal of empirical work has been done from this perspective.

The designer attempting to optimize an executive compensation program would be concerned with: (1) attracting and retaining high quality executives, (2) providing executives with incentives to exert sufficient effort and to make decisions that serve shareholders' interests, and (3) minimizing overall costs. We will consider briefly these elements of an optimal contract.

1. Inducing the executive to take and retain the position.

A successful CEO of a large public company undoubtedly possesses a rare combination of skills and instincts. The CEO must manage an organization with a large number of employees, provide the strategic direction for the firm, and decide when or whether the company should acquire other firms or be acquired. Individuals who possess the necessary attributes might be scarce ${ }^{9}$ and competition among firms, particularly for rising stars, might be intense. Of course, compensation is not the only factor in attracting and retaining talent at the very top of the corporate pyramid, but it is an important one.

To induce an executive to take and retain a position, then, a firm must offer an overall package of benefits that meets or exceeds the executive's opportunity cost. Call this opportunity cost the executive's "reservation value." An executive's reservation value is in part a function of her appetite for risk. A firm that requires a risk-averse executive to accept risky elements of compensation will have to provide more total compensation on an expected value basis to offset risk-bearing costs. For example, if a CEO candidate currently works for a firm that pays

tant works on the subject include Stephen A. Ross, The Economic Theory of Agency: The Principal's Problem, 63 Am Econ Rev 134 (1973); J.A. Mirrlees, The Optimal Structure of Incentives and Authority within an Organization, 7 Bell J Econ 105 (1976); Bengt Holmstrom, Moral Hazard and Observability, 10 Bell J Econ 74 (1979); Steven Shavell, Risk Sharing and Incentives in the Principal and Agent Relationship, 10 Bell J Econ 55 (1979); Bengt Holmstrom, Moral Hazard in Teams, 13 Bell J Econ 324 (1982); Sanford J. Grossman and Oliver D. Hart, An Analysis of the Principal-Agent Problem, 51 Econometrica 7 (1983); and Dilip Mookherjee, Optimal Incentive Schemes with Many Agents, 51 Rev Econ Stud 433 (1984).

9 See Charles P. Himmelberg and R.G. Hubbard, Incentive Pay and the Market for CEO's: An Analysis of Pay-for-Performance Sensitivity at 20, working paper (1999), available online at $<\mathrm{http} / /:$ www.columbia.edu/ $\sim \mathrm{cph} 15 />$ (visited May 4, 2002) (arguing that there is not an unlimited supply of CEOs who are able to run large companies). 
her a cash salary of $\$ 500,000$, another firm wishing to hire her and pay her in part with options will have to provide her-if she is risk-aversecompensation with an expected value greater than $\$ 500,000$.

Under the optimal contracting approach, inducing the executive to take and retain a position only provides a lower bound on compensation. A firm cannot pay less than the executive's reservation value, but it might wish to pay more in order to provide better incentives.

\section{Incentives to manage well.}

There are two dimensions to the executive incentive problem. A firm must provide incentives that induce the executive to expend effort as well as incentives that motivate the executive to make decisions that advance shareholders' interests.

As in any agency relationship, there is the risk that the agent will expend too little effort on the principal's behalf. That is, executives might have an incentive to work less than is optimal for shareholders as a group. This distortion arises because executives enjoy all of the benefits of their leisure time (or other non-work activities) but capture only a fraction of the value their work generates for the firm.

The second agency problem in most public companies is that executives might make decisions that maximize their own utility but that fail to maximize shareholder value. Such decisions might include the erection of lavish office buildings to house corporate staff or other excessive perquisite consumption; the selection of low-risk business strategies; attempts to block value-adding takeover attempts; the failure to reorganize and reduce the scope of operations when downsizing is called for; and the refusal to fire an incompetent subordinate because he is a close friend. The variety of critical decisions that may be faced by a CEO is extremely large, and the compensation device that properly aligns incentives in one case may be less effective in another. Moreover, the nature of the key decisions in the coming years often will be unforeseeable, thus complicating further the design of the optimal compensation plan.

\section{Costs.}

The executive's reservation value places a lower bound on the value of a compensation package and thus its cost to the company. But a firm may wish to pay executives much more than their reservation value to create incentives for behavior that increases shareholder value. Under the optimal contracting approach, shareholders should continue to give value to executives until the incremental cost of doing so outweighs the in- 
cremental benefit of the incentives produced. A compensation plan designer attempting to maximize shareholder value would consider alternative structures both in terms of their incentive benefits and their costs to the company. No scheme would be chosen, of course, if an alternative scheme could produce the same or better incentives at a lower cost to the company.

\section{B. The Limitations of the Optimal Contracting Approach}

There are three mechanisms that might produce executive compensation programs that are optimal for shareholders: (1) the board, acting at arm's length, selects the compensation arrangement that maximizes shareholder value; (2) although the board acts under the influence of management, executives are constrained by market forces to select the compensation arrangement that best serves shareholder interests; or (3) shareholders can use their rights under corporate law to block pay arrangements that are not optimal for shareholders, which forces executives to adopt arrangements that maximize shareholder value. Below we analyze in turn each of these mechanisms and show that they are unlikely to be sufficiently powerful to ensure that compensation arrangements closely follow the model suggested by optimal contracting. Before proceeding, it is worth stressing that our view is not that these mechanisms are useless in constraining executive compensation. As will be explained, these mechanisms, particularly the board of directors and market forces, do impose some constraints on executive compensation. However, these mechanisms are generally not strong enough to prevent large deviations from optimal contracting in directions that favor managers' interests.

\section{Limitations of the arm's length model of boards.}

The optimal contracting literature assumes explicitly or implicitly that, in setting executives' compensation, directors take an adversarial (or at least independent) position vis-à-vis the executives. It is acknowledged that management plays a role in supplying data and proposals. However, the board is viewed as serving shareholder interests exclusively in this process and bargaining with management in an arm's length fashion. Although some students of corporate governance have recognized the limitations of this view, ${ }^{10}$ their full force has not been generally appreciated in the literature on executive compensation.

10 See, for example, Victor Brudney, The Independent Director-Heavenly City or Potemkin Village?, 95 Harv L Rev 597 (1982). 
In exploring these limitations it will be helpful to begin with a brief description of the process of setting executive pay. In a large public corporation, the board of directors is responsible for determining the compensation of the CEO and other top executives. Typically, the board will adopt a multi-year compensation program for executives, including an option plan that provides bounds on the total amount of stock-based awards that can be made to senior executives and lower-level employees. The option plan might be put to a shareholder vote and ratified by shareholders. ${ }^{11}$ Operating within the plan, however, the board has full authority to fix the compensation of any given senior executives on a periodic basis. ${ }^{12}$

The directors of essentially all large U.S. public companies have established compensation committees to which they delegate this responsibility. ${ }^{13}$ A compensation committee typically is composed of three or four directors. ${ }^{14}$ In most firms, all or almost all of the directors serving on the committee are "independent." "15

Three primary factors have led to the increasing use of compensation committees composed entirely of (at least nominally) independent directors. First, investor advocacy organizations have long pushed for this improvement in corporate governance. ${ }^{16}$ Second, the tax code now provides corporations with a strong incentive to establish such committees. Since 1994, CEO and top officer pay in excess of \$1 million annu-

11 Ratification of these option plans is virtually certain. Incumbent managers face a meaningful chance of losing a vote only if there is an active proxy contest for control of the board. See Lucian A. Bebchuk and Marcel Kahan, A Framework for Analyzing Legal Policy towards Proxy Contests, 78 Cal L Rev 1071, 1074 (1990). The question of ratifying stock-based awards is not sufficiently weighty to induce a challenger to wage a campaign to replace the board. For a discussion of shareholder voting on option plans, see Part I.B.3.b.

12 See Stacey R. Kole, The Complexity of Compensation Contracts, 43 J Fin Econ 79, 101 (1997) (finding that shareholder-approved option plans in companies that are larger, more diversified, and more research-intensive tend to provide directors greater flexibility).

13 See Kenneth A. Bertsch, Rachel Leahey, and Hawie Haun, Board Practices (1998): The Structure and Compensation of Boards of Directors at S\&P Super 1500 Companies 19 (Investor Responsibility Research Center 1998).

14 See id at 6 (reporting that the average committee size ranged from 3.3 directors among S\&P Small Cap 600 firms to 4.2 directors among S\&P 500 firms).

15 Bertsch, Leahey, and Haun report that in 1998 the average percentage of independent directors on compensation committees ranged from 83.5 percent among S\&P Small Cap 600 firms to 91.9 percent among S\&P 500 firms. See id. Directors are defined in their study as independent if they are not employed by the firm or "affiliated." A director is considered "affiliated" if she is a former employee, a relative, a representative of a charity that receives contributions from the firm, a service provider, a supplier, a customer, or an interlocking director.

16 The current Teachers Insurance and Annuities Association/College Retirement Equities Fund ("TIAA/CREF") policy, for example, states that compensation committees should be independent, knowledgeable, and willing to use an outside compensation consultant in negotiating CEO compensation. See Fund Toughens on Executive Pay, Investor Rel Bus (Apr 3, 2000). 
ally per executive has not been deductible by a publicly held corporation unless the excess compensation consists of options or is based upon the achievement of performance goals that have been established by a compensation committee composed solely of independent outside directors. ${ }^{17}$ Third, the use of an independent compensation committee would, in the event of a legal challenge, result in more deferential review of the compensation program. ${ }^{18}$

Despite the nominal independence of most compensation committees, there are several reasons to be skeptical that the process of setting executive compensation approximates the arm's length ideal. The key problem is the pervasive influence of management, particularly the CEO, on all facets of the pay-setting process. ${ }^{19}$ Below we will discuss several reasons to expect large deviations from arm's length outcomes. First, managers influence the appointment of independent directors, which in many cases enables them to block the appointment of directors who are likely to try to bargain with the managers at arms' length. Secondly, once appointed, independent directors are influenced by board dynamics that make it difficult for them to deal with managers in a truly arm's length way, especially if other directors have no interest in confronting the managers over their pay. Finally, even if directors were otherwise inclined to challenge managers on the issue of executive compensation, they would likely have neither the financial incentive nor sufficient information to do so. We will discuss each of these problems in turn.

a) Management influence over director appointment. Management's domination of the compensation process begins with the selection of the corporation's directors, who form the pool of candidates for the

\footnotetext{
17 See Internal Revenue Code ("IRC") § 162(m), codified at 26 USC § 162 (Supp 2001). The employees whose compensation is covered by this rule include the CEO, or individual acting in that capacity, and the four most highly compensated officers other than the CEO, whose compensation must be reported under the Securities Exchange Act of 1934. See 26 CFR $\$ 1.162-27$ (c)(2) (2002) (defining the employees covered under IRC $\S 162(\mathrm{~m})$ ). Non-employee directors who serve as consultants or who otherwise receive direct or indirect remuneration from the firm in a capacity other than as a director do not qualify as outside directors for the purposes of Section 162(m). See 26 CFR $§ 1.162-27(\mathrm{e})(3)$.

The enactment of Section $162(\mathrm{~m})$ has appeared to reduce some salaries and salary growth rates and increase the sensitivity of pay to performance. See Tod Perry and Marc Zenner, Pay for Performance?: Government Regulation and the Structure of Compensation Contracts, 62 J Fin Econ 453-88 (2001).

18 See Robert Charles Clark, Corporate Law $\$ 6.1$ at 194 (Little, Brown 1986).

19 Even the timing of stock option awards may be influenced to favor senior management. Yermack finds that that the timing of CEO option awards tends to precede immediately favorable movements in company stock prices. See David Yermack, Good Timing: CEO Stock Option Awards and Company News Announcements, 52 J Fin 449, 450 (1997). Managers can also release bad news prior to the grant date of options in order to reduce the strike price of the options (which is almost always set to the grant-date market price). See Keith W. Chauvin and Cathy Shenoy, Stock Price Decreases Prior to Executive Stock Option Grants, 7 J Corp Fin: Cont, Gov \& Org 53 (2001) (reporting abnormal stock price declines during the 10day period preceding the grant date).
} 
compensation committee. Traditionally, the CEO has dominated the director nomination process. ${ }^{20}$ While most boards employ a nominating committee, the CEO often formally serves on the committee. ${ }^{21}$ A 1998 survey found that only 27 percent of S\&P 1500 firms had fully independent nominating committees. ${ }^{22}$ And even when the CEO does not sit on the nominating committee, his influence on the nomination process is still generally thought to be considerable. ${ }^{23}$ The CEO can use his power and influence to encourage the appointment -and reappointment of independent directors who are not likely to challenge his compensation.

b) Board dynamics. Most directors believe that their primary responsibility is to monitor the CEO's performance and, if necessary, fire him and hire a suitable replacement. ${ }^{24}$ Outside of this unfortunate circumstance, however, the directors are expected to support the CEO. Those who cannot do so in good faith are expected to step down. ${ }^{25}$ Overall, board meetings and processes are characterized by an emphasis on courtesy, politeness, and deference to the CEO. ${ }^{26}$

(i) The "support or fire" model. The role of the board of directors, as it is normally conceived, is to focus on the big picture and ensure that the personnel and strategies necessary for the company's success are in place. Although setting executive compensation clearly is a board responsibility, scrutinizing the level or form of executive compensation proposed by an effective CEO (or his compensation consultant)

20 See Brian G.M. Main, et al, The CEO, the Board of Directors, and Executive Compensation: Economic and Psychological Perspectives, 11 Indus \& Corp Change 293, 302-03 (1995); Brudney, 95 Harv L Rev at 610 n 39 (cited in note 10); Benjamin E. Hermalin and Michael S. Weisbach, Endogenously Chosen Boards of Directors and Their Monitoring of the CEO, 88 Am Econ Rev 96, 97 (1998). For a review of the economic literature on boards of directors, see Benjamin E. Hermalin and Michael S. Weisbach, Boards of Directors as an Endogenously Determined Institution: A Survey of the Economic Literature at 10-12, NBER Working Paper No 8161 (2001), available online at <http://papers.nber.org/papers/w8161.pdf> (visited Apr 27, 2002).

21 See Anil Shivdasani and David Yermack, CEO Involvement in the Selection of New Board Members: An Empirical Analysis, 54 J Fin 1829, 1834 (1999) (reporting that 78 percent of 341 publicly traded Fortune 500 firms in 1994 had a nominating committee, and that in 33 percent of those firms the CEO was a member of the nominating committee).

22 See Bertsch, Leahey, and Haun, Board Practices at 18 (cited in note 13). In the study, directors are classified as employees, affiliated, or independent. A director is deemed affiliated if, as disclosed in the proxy statement, he or she is a former employee, a relative of an executive, a representative of a charity that receives contributions from the firm, or a designated interlocking director. Id at 9-10.

23 See Main, 11 Indus \& Corp Change at 293, 302-03 (cited in note 20) (suggesting that director nominations are "dominated by the CEO").

24 See Crystal, In Search of Excess (cited in note 6); Jay W. Lorsch and Elizabeth M. MacIver, Pawns or Potentates?: The Reality of America's Corporate Boards 64 (Harvard Business School 1989).

25 See Main, 11 Indus \& Corp Change at 304 (cited in note 20) (documenting the social pressure on directors not to actively challenge the CEO).

26 See Michael C. Jensen, The Modern Industrial Revolution, Exit, and the Failure of Internal Control Systems, 48 J Fin 831, 863 (1993) (noting that the board's "politeness and courtesy" comes at the expense of "truth and frankness"). 
runs counter to the predominant "support or fire" model of the board of directors. ${ }^{27}$ Independent directors are thus likely to be reluctant to confront an effective CEO regarding the amount of his pay and perquisites. This reluctance might stem from a notion that their effort and scrutiny are better focused on policy matters, or independent directors' perception that they are not as knowledgeable about compensation issues as the management or the compensation consultant.

(ii) Social dynamics. Although the use of a compensation committee comprised solely of independent directors mitigates somewhat the influence of the CEO on executive compensation, it is no panacea. The social dynamics of the board, the members of which have been selected in large part by the CEO or with his input, ${ }^{28}$ play an important role in deterring objection to executive compensation programs.

It is well known that individuals working within a group feel pressure to placate group members, often at the expense of interests that are not directly represented at the table. ${ }^{29}$ The relationship between the CEO and the board is also likely to produce additional dynamics specific to that particular setting. Main, O'Reilly, and Wade have found that directors are influenced by notions of reciprocity, authority, and similarity in their deliberations concerning executive compensation. ${ }^{30}$ Specifically, they find that compensation committee chairmen who are appointed after the CEO takes office tend to reciprocate by awarding higher CEO compensation. ${ }^{31}$ They also find a significant association be-

27 There is evidence indicating that boards do in fact sometimes fire poorly performing CEOs. See David J. Denis and Diane K. Denis, Performance Changes Following Top Management Dismissals, 50 J Fin 1029,1055 (1995) (finding that forced CEO resignations are rare and that two-thirds of those that occur are caused by factors other than board monitoring, such as blockholder pressure or a takeover attempt); Mark R. Huson, Robert Parrino, and Laura T. Starks, Internal Monitoring Mechanisms and CEO Turnover: A LongTerm Perspective, 56 J Fin 2265, 2279 (2001) (finding that 23.4 percent of turnovers in large public U.S. firms during the period 1989-1994 were involuntary). Not surprisingly, firms with outsider-dominated boards are significantly more likely to remove the CEO on the basis of poor stock performance than are firms with insider-dominated boards. See Michael S. Weisbach, Outside Directors and CEO Turnover, $20 \mathrm{~J}$ Fin Econ 431, 453-54 (1988). See also Warren Boeker, Power and Managerial Dismissal: Scapegoating at the Top, 37 Admin Sci Q 400 (1992) (finding that the likelihood that a poorly performing CEO of semiconductor firm will be replaced decreases as the percentage of inside directors increases).

28 See Main, 11 Indus \& Corp Change at 302-03 (cited in note 20) (reporting the CEO domination of board member selection)

29 See Melvin A. Eisenberg, The Compensation of Chief Executive Officers and Directors of Publicly Held Corporations, SE39 ALI-ABA 103, 117-18 (1999).

30 Main, 11 Indus \& Corp Change at 304 (cited in note 20). For other research on small group dynamics, see generally J.S. Coleman, Constructed Organizations: First Principles, 7 J L, Econ, \& Org 7 (1991); R.B. Cialdini, Influence: The New Psychology of Modern Persuasion (Morrow 1993).

31 Main, 11 Indus \& Corp Change at 307-08 (cited in note 20). Similarly, CEO pay tends to be higher and the CEO is more likely to have a golden parachute when more of the outside directors have been appointed by the $\mathrm{CEO}$. 
tween the compensation level of outsiders who serve on the compensation committee and CEO pay. ${ }^{32}$

(iii) Self-serving cognitive dissonance. It has been suggested that a CEO benefits when a well-paid CEO of another firm sits on the compensation committee. ${ }^{33}$ If so, this phenomenon could be viewed as pure self-interest: by approving high compensation for the evaluated CEO, the outside CEO increases the compensation baseline. Alternatively, it may be seen as a form of cognitive dissonance wherein the outside CEO internally justifies his high pay and that of the subject CEO by viewing the compensation data in the most favorable light. In 1998, 25 percent of compensation committee members were CEOs, and a number of highly compensated CEOs served on several compensation committees. $^{34}$

c) Insufficient incentives. CEO control over the board nomination process and board dynamics militate against effective executive compensation oversight by independent directors. Unfortunately, outside directors generally lack the economic incentive to overcome these forces. The benefits of attempting to curb excessive executive compensation are low, while the potential costs are high.

(i) Economic benefits. Although stock-based compensation for outside directors is on the rise-81 percent of S\&P 500 firms awarded directors stock or options in $1997^{35}$ - the direct benefit to independent directors of reducing the CEO's compensation remains insignificant in almost all cases. ${ }^{36}$ Even if excessive CEO pay results in somewhat higher compensation throughout the managerial ranks, the impact is unlikely to be felt by a director who holds options to purchase only a very small fraction of the company's shares. ${ }^{37}$ Further, as we will discuss

32 Id at 319-20; Charles A. O'Reilly, et al, Overpaid CEO's and Underpaid Managers: Equity and Executive Compensation at 24, working paper (1998) (on file with authors). The relative social status of the CEO also affects his pay. See Maura A. Belliveau, Charles O'Reilly, and James B. Wade, Social Capital at the Top: Effects of Social Similarity and Status on CEO Compensation, 39 Acad Mgmt J 1568, 1581-84 (1996) (finding no support for the proposition that social similarity between the CEO and the chair of compensation committee increases CEO compensation, but finding that CEOs with relatively high social status versus other CEOs and CEOs with high social status versus chairmen of the compensation committees do receive higher compensation).

33 See Crystal, In Search of Excess at 227 (cited in note 6) (referring to the well-paid CEO/director as a "social reference" for the CEO).

34 Bertsch, Board Practices at 20 (cited in note 13).

35 Id at 37.

36 See George P. Baker, et al, Compensation and Incentives: Practice vs. Theory, 43 J Fin 593, 614 (1988) (arguing that directors fail to create proper executive pay arrangements because the directors bear a large share of the nonpecuniary costs of creating the arrangements and receive little monetary benefit from improved compensation practices).

37 Independent directors with more substantial equity interests would have more incentive to limit executive compensation. See Richard Cyert, et al, Corporate Governance, Ownership Structure, and CEO 
below, the incremental compensation cost incurred by a company with less than vigilant directors is unlikely to reduce the stock price sufficiently to spark a hostile takeover attempt and threaten the independent directors' positions on the board.

(ii) Economic costs. While the benefit to independent directors of reducing the CEO's salary is minimal, the cost of trying to do so could be considerable. As explained previously, CEOs have significant influence on the appointment and reappointment of outside directors. This influence makes director compensation activism costly in two ways. First, and most importantly, the CEO has an incentive to throw an uncooperative director off the board (or not reappoint the director when his term expires). In many cases, the CEO will have the power, through his relationships with other board members, to do so. If the director is expelled or his directorship is not renewed, the director will lose his compensation $^{38}$ and other economic and noneconomic benefits he gets from his board position, including prestige and business and social connections. ${ }^{39}$ The risk of losing one's directorship as a result of challenging the CEO's compensation must be orders of magnitude greater than the increase in risk of a takeover resulting from the CEO's higher salary. ${ }^{40}$

Second, there is likely to be a reputational cost of trying to reduce the CEO's compensation. In particular, other CEOs are unlikely to appoint or reappoint to their boards a director with a reputation for challenging executive compensation. Thus, attempting to reduce the CEO's compensation might jeopardize not only the director's salary and perks associated with that board position, but also the salary and perks associ-

Compensation at 17-20, working paper (1997) (on file with authors) (finding that CEO pay is negatively related to the level of equity holdings of compensation committee members). A case for increasing stock grants to independent directors is forcefully presented in Charles M. Elson, Executive Over-CompensationA Board-Based Solution, 34 BC L Rev, 937, 981-83 (1993) (arguing that granting stock to outside directors would better align their interests with that of shareholders).

38 In addition to equity-based compensation, directors usually receive a cash salary. See Eisenberg, SE39 ALI-ABA at 132 (cited in note 29) (reporting that the average Fortune 500 director's fee increased from $\$ 30,000$ in 1980 to $\$ 50,000$ in 1994).

39 It is reasonable to think that in many cases a CEO would be able to rally a majority of board members to his side to replace the problem director when the director's term expires. Inside directors can be mobilized by the CEO because they are beholden to the CEO. Outside directors may well go along with the $\mathrm{CEO}$ to protect their own positions, to curry favor with the CEO, who has influence over board compensation, or simply to make board meetings less fractious and unpleasant.

40 A study of the determinants of CEO compensation in Australia finds that CEO compensation is decreasing as the amount of equity held by outside directors and increasing as the salary paid outside directors rises. See Robert Evans and John Evans, The Influence of Non-Executive Director Control and Rewards on CEO Remuneration: Australian Evidence at 18-19, working paper (2000), available online at $<$ http://www.efmaefm.org/jevans2.pdf $>$ (visited Apr 27, 2002). The first finding suggests that outside directors are more likely to curb CEO compensation when the benefits of reducing CEO compensation are higher. The second suggests that outside directors are less likely to curb CEO compensation when the potential costs (the loss of position and salary) are higher. 
ated with membership on other boards. Finally, reducing the CEO's compensation would indirectly hurt the independent director if the director is a CEO whose pay is linked broadly to that of other CEOs.

(iii) The market for directors. Fama and Jensen have argued that independent directors have an incentive to develop reputations as experts in decision control, which they can do by safeguarding shareholder interests. ${ }^{42}$ Their idea is as follows: Independent directors normally are CEOs or other decision managers in their primary jobs, and the value of their human capital depends on their decision management reputation. Effective independent directors signal to the managerial labor market that they are indeed experts in decision control. Thus, Fama and Jensen might argue that - in addition to possibly increasing the value of the director's options - attempting to reduce CEO compensation yields reputational benefits.

While this mechanism may work in certain cases, we are skeptical about its effect on many, if not most, directors. First, the signal provided by independent directorships is likely to be quite noisy, particularly when the board is large and responsibilities are diffuse. Second, and relatedly, the managerial labor market is more likely to focus on the manager's performance in his primary role rather than in his independent directorships. Third, there are likely to be a considerable number of independent directors who are interested less in establishing reputations as "expert decisionmakers" than in keeping their current board seats and perhaps joining other boards. As we noted above, CEOs have considerable influence in the choice of independent directors and will tend to prefer candidates who are unlikely to challenge their compensation. Thus, for a director aspiring to additional board positions, the "market" for directors creates incentives not to challenge the CEO on the issue of his compensation but rather to accommodate the CEO's wishes.

Given the process of director selection and retention, board and committee processes and dynamics, and the lack of an effective incentive structure, it is unlikely that Fama and Jensen's "decision control expert" story will result in independent directors engaging in effective arm's length bargaining with the CEO over his compensation. Indeed,

\footnotetext{
41 See Yermack, 52 J Fin at 461-62 (cited in note 19).

42 Eugene F. Fama and Michael C. Jensen, Separation of Ownership and Control, 26 J L \& Econ 301, $315(1983)$.

43 To be sure, one could argue that market forces will prevent CEOs from appointing directors who are too pliant and instead will force them to appoint directors willing and able to engage in arm's length bargaining with the CEO. This is a variant of the argument that even if the CEO has influence over the board, market forces will force the board to negotiate with the CEO at arm's length. We will address this argument shortly.
} 
reputation is likely to limit the degree to which the independent directors are willing to challenge management in this area.

d) Information disparities. We have just shown that directors, including independent directors, are likely to have neither the inclination nor the incentive to engage in arm's length bargaining with the CEO. We now wish to point out that even if directors have the inclination and incentive to negotiate for CEO compensation that maximizes shareholder value, they will usually lack the information to do so effectively.

The CEO, by way of his personnel department, controls much of the information that reaches the committee. TIAA/CREF has recommended that compensation committees be "willing" to employ an independent compensation consultant, but normally the firm (in other words, management) employs the consultant that provides the data to the committee. ${ }^{45}$ Even if the consultant's compensation data are perfectly accurate, there is a great deal of flexibility and discretion involved in choosing the companies that are used for comparison, determining the economic scenarios that will be presented to the committee, and in general deciding what data will be presented and how. ${ }^{46}$ Because managers choose which compensation consultants to hire, the consultants have a clear incentive to make recommendations favorable to managers.

To be sure, the consultant is somewhat constrained by reputational considerations - she cannot propose a pay package that is obviously excessive. But within the range of flexibility and discretion, the consultant has an incentive to provide information in a way that is most beneficial to managers. Thus, the information presented and the way it is framed will be chosen with an eye toward maximizing managers' compensation.

Of course, independent directors are not required to follow the compensation consultant's recommendation. They could attempt to solicit other proposals or come up with a package on their own. But as a practical matter, independent directors have only limited time and resources available to devote to increasingly complex compensation issues. $^{47}$ Thus, directors will rely heavily, if not almost exclusively, on the information and proposal provided by the compensation consultant.

e) Larger and smaller departures from the arm's length model. We wish to emphasize that the various factors undermining the board's ability to engage in arm's length bargaining - management control over director appointment, board social dynamics, directors' insufficient and

\footnotetext{
44 See Fund Toughens on Executive Pay, Investor Rel Bus (cited in note 16).

45 See Crystal, In Search of Excess at 229-30 (cited in note 6).

46 See id.

47 See Main, 11 Indus \& Corp Change at 305 (cited in note 20); Brudney, 95 Harv L Rev at 609 (cited in note 10); Jensen, $48 \mathrm{~J}$ Fin at $863 \mathrm{n} 35$ (cited in note 26).
} 
distorted economic incentives, and informational barriers - are stronger in some cases and weaker in others. Thus, firms can differ in the extent to which the compensation-setting process deviates from arm's length bargaining.

For example, CEO influence over director appointment and the strength of the personal relationships between the CEO and board members will vary from firm to firm. As a result, some CEOs will have more power than others. Nevertheless, in most companies, at least some of the factors undermining the board's willingness and ability to engage in arm's length bargaining over executive compensation are present. Therefore, some departure from optimal contracting is to be expected.

It is worth noting in this connection the trend among firms in the last decade or so to increase the number and power of "independent directors." ${ }^{48}$ There are data suggesting that outside directors have increasing influence over the composition of board committees and that they constitute a majority of most board committees, including the nominating committee. Thus, corporate governance experts have concluded that boards have become more effective monitors of CEO performance.

This trend may have reduced the power of the CEO in certain companies. In some companies, directors are more independent from the executives and are thus more willing to fire executives when they perform particularly poorly. In fact, during the last twenty years CEO tenure has declined and CEO terminations have increased ${ }_{53}^{22}$ - trends that are attributed to boards becoming more independent.

48 See, for example, Sanjai Bhagat and Bernard Black, The Uncertain Relationship between Board Composition and Firm Performance, 54 Bus Law 921, 922 (1999).

49 Korn/Ferry International, Korn/Ferry's 28th Annual Board of Directors Study Finds CEO, Board Evaluations on Upswing, Outsiders Deciding Committee Membership, Compensation Static, available online at $<$ http://www.kornferry.com/pr/pr_01_0904_board_evaluations.asp $>$ (visited Apr 14, 2002) (reporting survey results indicating that the percentage of firms in which the CEO chooses committee chairs and members has declined from 57 percent in 1996 to 37 percent in 2001).

50 Korn/Ferry International, 27th Annual Board of Directors Study 2000. See also Anil Shivdasani and David Yermack, CEO Involvement in the Selection of New Board Members: An Empirical Analysis, $54 \mathrm{~J}$ Fin 1829, 1851 (1999) (reporting that the influence of CEOs over the selection of board members has declined).

51 See, for example, Ira M. Millstein and Paul W. MacAvoy, The Active Board of Directors and Performance of the Large Publicly-Traded Corporation, 98 Colum L Rev 1283 (1998); Melvin A. Eisenberg, Corporate Law and Social Norms, 99 Colum L Rev 1253, 1268 (1999); Mark J. Loewenstein, The Conundrum of Executive Compensation, 35 Wake Forest L Rev 1, 15 (2000).

52 Tom Neff, Anatomy of a CEO, Chief Exec 3032 (Feb 1, 2001) (reporting that the median tenure of CEOs in office declined from seven years in 1980 to five years in 2000); Denis B.K. Lyons, CEO Casualties: A Battlefront Report, Directors \& Boards 43 (Summer 1999) (reporting that the percentage of Fortune 100 companies whose CEOs have tenure of five years or less has increased from 46 percent in 1980 to 58 percent in 1998).

53 Lyons, CEO Casualties, Directors \& Boards at 43 (cited in note 52) (listing "increasingly independent boards" as an important factor contributing to the increase in CEO turnover). 
However, although boards are more likely to fire CEOs who are performing particularly poorly, the formulation of executive pay packages is not likely to be characterized by arm's length bargaining in the great majority of firms. Even in those firms where a majority of the directors are sufficiently "independent" to fire the CEO in the event of dismal performance, the directors will generally not have an economic incentive and sufficient information to attempt to negotiate down the compensation of a CEO who is performing sufficiently well not to be fired. Such a CEO is likely to stay in his position for some time, and thus could retaliate against a director who sought to limit his compensation.

To be sure, in the future there could be changes of a more fundamental nature that bring us closer to an arm's length model. There is good reason to believe, however, that currently negotiations between executives and the board over executive compensation tend to be far from that model.

\section{Limitations on the power of market forces.}

Directors are unlikely to bargain with management over their compensation in a manner that approaches the arm's length ideal. However, we must consider whether the CEO and more junior executives will be induced by market forces not to push for anything other than optimal compensation contracts.

There is an important school of thought in corporate law and finance scholarship that takes the view that markets for managerial labor, corporate control, capital, and products effectively align managers' and shareholders' interests. 'As one of us has argued in earlier work, however, these market mechanisms cannot be relied upon to align managers' and shareholders' interests with respect to significantly redistributive actions - actions by which the managers can transfer to themselves value $_{5}$ that is substantial relative to the resulting loss to shareholders. ${ }^{55}$ The

\footnotetext{
54 See Easterbrook, 9 Del J Corp L at 543-53 (cited in note 4); Daniel R. Fischel, The "Race to the Bottom" Revisited: Reflections on Recent Developments in Delaware's Corporation Law, 76 Nw U L Rev 913, 916-20 (1982); Eugene F. Fama, Agency Problems and the Theory of the Firm, 88 J Polit Econ 288, 289 (1980).

55 See Lucian A. Bebchuk, Federalism and the Corporation: The Desirable Limits on State Competition in Corporate Law, 105 Harv L Rev 1437, 1461-67 (1992) (arguing that market forces cannot ensure that managers' reincorporation decisions are those that are optimal for shareholders); Lucian A. Bebchuk, Limiting Contractual Freedom in Corporate Law: The Desirable Constraints on Charter Amendments, 102 Harv L Rev 1820, 1840-46 (1989) (arguing that market forces cannot ensure that managers' decisions concerning charter amendments are those that are best for shareholders); Lucian A. Bebchuk and Mark J. Roe, $A$ Theory of Path Dependence in Corporate Ownership and Governance, 52 Stan L Rev 127, 142-53 (1999) (arguing that market forces cannot ensure that managers and controlling shareholders move to whatever ownership structure becomes efficient as legal rules change).
} 
payment of executive compensation, which approaches a direct transfer from shareholders to management, would seem to be an especially clear case of a significantly redistributive action for which market forces will provide insufficient discipline. We will briefly review the market forces that bear upon managerial behavior activity and discuss why they are unlikely to impose significant restraints on executive compensation.

a) Managerial labor markets. Several labor market mechanisms tend to align the interests of executives with those of shareholders. The most important mechanisms are executives' compensation plans and their equity holdings. The typical CEO's compensation package is composed of a base salary, an annual bonus, stock options and/or restricted shares, and often other long-term incentive elements. ${ }^{5}$ Each of these components is sensitive to firm performance to a greater or lesser degree. To the extent executives retain the stock acquired by exercising their options (or acquired through restricted stock programs), they will have an additional incentive to generate shareholder value.

Over the past two decades, the increasing use of stock options has boosted the sensitivity of the average CEO's wealth to firm performance by an order of magnitude. However, given the enormous size of large U.S. companies, the absolute sensitivity of CEO wealth to performance remains small. For a $\$ 1000$ change in firm value, the wealth of the average $\mathrm{CEO}$ of a large public corporation currently changes by only about $\$ 10$. All else being equal, a CEO who wrote himself a check for an extra $\$ 1000$ would thus net about $\$ 990$ after taking into account the impact of the change in firm value on his shares and options.

To be sure, all else is not equal. Although there appears to be a widening $_{5}$ gap between the compensation of U.S. CEOs and junior executives, there is some evidence that when CEOs are overpaid (or underpaid), a diminishing echo effect is felt throughout the organization.

\footnotetext{
56 See Murphy, Executive Compensation at 2497-2517 (cited in note 2).

57 Perry and Zenner report that in 1997 the median S\&P 1500 CEO stood to gain or lose $\$ 11.50$ per $\$ 1000$ of shareholder gain or loss. See Perry and Zenner, 35 Wake Forest L Rev at 149 (cited in note 1). Similarly, Hall and Liebman have estimated that 1998 CEO wealth-to-shareholder-value sensitivity was approximately $\$ 11$ per $\$ 1000$, based on a firm with $\$ 1$ billion market capitalization. See Brian J. Hall and Jeffrey B. Liebman, The Taxation of Executive Compensation at figure 1, NBER Working Paper No 7596 (Mar 2000), available online at $<\mathrm{http}$ //papers.nber.org/papers/w7596.pdf $>$ (visited Apr 27, 2002). These figures exclude an adjustment for risk of dismissal. CEO wealth-to-shareholder-value sensitivity had been lower in the past. Using 1974-1986 data, Jensen and Murphy had calculated a median CEO wealth-to-shareholdervalue sensitivity of $\$ 3.25$ per $\$ 1000$, a figure that included a $\$ 0.30$ per $\$ 1000$ adjustment for risk of dismissal. See Michael Jensen and Kevin J. Murphy, Performance Pay and Top-Management Incentives, $98 \mathrm{~J}$ Polit Econ 225, 261 (1990).

58 See John M. Abowd and Michael L. Bognanno, International Differences in Executive and Managerial Compensation, in R. Freeman and L. Katz, eds, Differences and Changes in Wage Structures 67, 83 (Chicago 1995).

59 See O'Reilly, et al, Overpaid CEO's at 24 (cited in note 32) (noting that overcompensation of the
} 
Moreover, a large gap between the compensation of the CEO and that of his subordinates has been shown to be associated with higher rates of managerial turnover. ${ }^{60}$ Hence, a CEO might also take these factors into account before awarding himself a pay raise. Nevertheless, the sensitivity of their wealth to firm value, by itself, would dissuade few CEOs from seeking to increase their compensation.

Of course, compensation is just one element of the managerial labor market. Executives are also concerned with the possibilities of promotion or being tapped for higher-level positions by other firms. However, for the $\mathrm{CEO}$ - the person driving the executive compensation processinternal promotion is, of course, impossible. External promotion is always a possibility: she could become the CEO of a larger or more prestigious firm. But most CEO positions are filled internally. For the CEO, there are likely to be few other jobs that are both available and more desirable than her current one. Not surprisingly, the overwhelming majority of CEOs do not go on to become CEOs of other firms.

In any event, the ability to get another CEO job will depend on the CEO's overall performance at her current firm, not on the amount of rent extracted. Thus, the possibility of being hired for another CEO position is unlikely to deter a CEO from extracting rents. Indeed, when CEO do get new jobs, ${ }^{63}$ the initial hiring grants for the new jobs are highly correlated with the value of the unvested options and restricted stock the CEOs leave behind. ${ }^{64}$ Thus, if the prospect of being hired elsewhere has any effect on the pay level desired by CEOs, the effect will likely be in the direction of increasing this level.

Executives will also be concerned about the possibility of dismissal. But the risk of being fired also depends more upon overall performance than on the CEO's level of compensation. In any event, this risk is small. In their seminal 1990 study, Jensen and Murphy calculated

\footnotetext{
CEO leads to overcompensation in the lower ranks of employees).

60 See id at 25. Vertical pay inequity within an organization might also be associated with poorer product quality. See Douglas M. Cowherd and David I. Levine, Product Quality and Pay Equity between Lower-Level Employees and Top Management: An Investigation of Distributive Justice Theory, 37 Admin Sci Q 302, 316 (1992).

61 See C. Edward Fee and Charles J. Hadlock, Raids, Rewards, and Reputations in the Market for CEO Talent at 13, working paper (2001), available online at <http://www.afajof.org/Pdf/ meeting/2002/fee_paper.pdf> (visited Apr 27, 2002) (reporting that in a sample of 1200 CEO hires during the period 1990-98, 73.5 percent were internal hires).

62 See Melvin A. Eisenberg, The Structure of Corporation Law, 89 Colum L Rev 1461, 1495 (1989).

63 The probability of being hired as CEO for another firm (which is low) is positively related to the stock price performance at one's current firm. See Fee and Hadlock, Raids, Rewards, and Reputations at 2125 (cited in note 61).

64 See id at 36 (finding a positive correlation between forfeited equity positions and a CEO's new compensation package).
} 
that the median CEO suffers an expected dismissal-related wealth reduction of $\$ 0.30$ per $\$ 1000$ reduction in shareholder value. ${ }^{65}$ It seems highly unlikely that the small added threat of dismissal would dissuade a CEO from granting himself and perhaps other executives increased compensation.

b) Market for corporate control. The market for corporate control is also viewed as a strong force aligning the interests of management and shareholders. ${ }^{66}$ A company whose share price sags should become more vulnerable to a hostile takeover, which would likely cause the executives to lose their positions, pay, and perquisites.

The takeover threat, however, is unlikely to discourage managers from seeking to boost their compensation. Consider an executive of a $\$ 10$ billion company who contemplates increasing executive compensation by an amount with a present value of $\$ 100$ million. Obviously, the direct benefit to the executive is very large. The cost to the executive is the enhanced risk of takeover and ouster. However, the increase in takeover risk resulting from a 1 percent reduction in firm value is bound to be quite limited.

Even the commentators who believe most fervently in the disciplining force of takeovers admit that control transactions are very costly and useful only as a response to substantial performance shortfalls. ${ }^{68}$ Excessive compensation might be a symptom of more pervasive management shortcomings, but the limited evidence available does not support the proposition that overcompensation increases takeover risk substantially.

To be sure, the market for corporate control does impose some constraint on increasing compensation. At a certain point, shareholders might become sufficiently outraged to be willing to support outside challengers or bidders in a control contest. The main point, however, is

65 See Jensen and Murphy, $98 \mathrm{~J}$ Polit Econ at 242 (cited in note 57).

66 See Easterbrook, 9 Del J Corp L at 564-70 (cited in note 4); Henry G. Manne, Mergers and the Market for Corporate Control, 73 J Polit Econ 110 (1965). Despite widespread adoption of poison pills and other takeover defenses, the corporate control market has remained active. See John C. Coates IV, Takeover Defenses in the Shadow of the Pill: A Critique of the Scientific Evidence, 79 Tex L Rev 271, 276 (2000).

67 This simplified example ignores the compensation echo effect we mentioned in the prior subsection, but that effect does not disturb the conclusion that the direct benefit of increased compensation is significantly larger than the expected cost.

68 Easterbrook suggests that a potential increase in value of about 20 percent is needed to trigger a control transaction. See Easterbrook, 9 Del J Corp L at 567 (cited in note 4).

69 A study of Forbes 800 firms in the 1980s determined that takeover bids were more common in industries in which CEOs were overpaid, but found no significant difference between the compensation of the CEOs of firms that were and were not targeted for takeover within these industries. See Anup Agrawal and Ralph A. Walking, Executive Careers and Compensation Surrounding Takeover Bids, 49 J Fin 985 , 986 (1994). 
that management pay could substantially exceed the amount that would be consistent with optimal contracting without creating much additional risk of a takeover.

c) Market for additional capital. Another source of market discipline might arise from the possibility that the firm will need to return to the market for additional equity capital in order to support expansion. The prospect of needing to sell shares to the public might cause a valuemaximizing management team to maintain restraint and develop a reputation as conservative self-compensators.

The failure of managers to limit tightly their pay, however, is unlikely to impede the firm's access to equity capital. Instead, a pattern of excessive self-compensation will raise only slightly a firm's cost of capital. Taking managers' excessive compensation into account, future investors will pay something less for the firm's shares in a secondary offering than they would otherwise. Thus, more shares would have to be issued to raise a given amount of capital. Of course, this effect leads to a reduction in value that is borne by all existing shareholders, including the executive team. But again, the impact of this reduction in share value on managerial wealth and on the likelihood of ouster via takeover will be considerably less than the direct benefit of taking additional compensation.

d) Product markets. A final potential external constraint on management behavior is the one created by competition in product markets. In a competitive market, it is argued, inefficient behavior produces competitive disadvantage, shrinking profits, and business contraction or failure. Although this effect may discourage management from acting in ways that decrease productivity, the redistribution of firm profits from shareholders to executives has no significant effect on the operational efficiency of the company, and hence this factor will not inhibit excessive compensation.

e) Overall force. Even in the aggregate, the foregoing market forces are unlikely to impose tight constraints on executive compensation. To be sure, they might impose some constraints and deter managers from deviating extremely far from optimal contracting arrangements. The analysis indicates that the incentives for restraint provided by the executives' stock and option holdings outweigh any other incentives to restrain pay and that even these direct incentives are far from sufficient to induce managerial self-discipline with regard to such a significantly redistributive matter as executive compensation. The conclusion that mar-

70 See Easterbrook, 9 Del J Corp L at 557 (cited in note 4).

71 See Eisenberg, 89 Colum L Rev at 1489 (cited in note 62). 
ket forces do not impose tight constraints on executive compensation is supported by evidence indicating that non-market factors, including the CEO's power yis-à-vis the board, are important determinants of CEO compensation.

3. Limitations on the power of shareholders.

Although neither market forces nor bargaining between the board and the CEO is likely to ensure optimal contracting, in theory such contracting could arise if shareholders had the power to block executive compensation arrangements that they did not believe to be optimal. Shareholders have one or two mechanisms at their disposal that, in principle, could be used to challenge executive compensation arrangements: derivative litigation and, in some cases, the ability to vote against employee stock option plans. As we explain below, however, neither of these mechanisms imposes much of a constraint on executive compensation.

a) Derivative litigation. Even though corporate boards and market forces cannot ensure that executive compensation arrangements are close to those suggested by optimal contracting, optimal pay arrangements might arise if shareholders could use the courts to throw out compensation packages that do not maximize shareholder value. In fact, corporate law permits shareholders to challenge a particular compensation package under a variety of doctrines. However, the obstacles to the success of such a lawsuit all but ensure that courts never review the substantive merits of management compensation arrangements. Thus, as a practical matter, judicial review fails to impose any constraint on executive pay.

To overturn a board's decision to grant a particular pay package, shareholders would be required to show that the board had violated its duty of care, committed "waste," or breached its duty of loyalty. As we will explain, it is all but impossible to prove any of these violations. Before describing each of these legal standards, however, it will be useful to examine the procedural barriers that make it extremely unlikely that shareholders will even get to the stage where such claims are heard.

72 See, for example, John E. Core, et al, Corporate Governance, Chief Executive Officer Compensation, and Firm Performance, 51 J Fin Econ 371, 388 (1999). This evidence that executive pay is affected by executive power is presented and discussed in detail in Part III.G.

73 See Barris, 68 Ind L J at 82 (cited in note 6) (reporting that in almost all cases since 1900 involving publicly traded firms, courts have refused to overturn board compensation decisions).

74 This discussion of derivative litigation focuses primarily on the corporate law of Delaware, the state in which the most large publicly traded firms are incorporated. 
Excessive compensation does not hurt shareholders directly, but rather indirectly through their equity interests in the firm. Thus, shareholders cannot sue the board directly for claims relating to executive pay. To challenge board decisions involving executive compensation, shareholders generally must file a derivative suit - a suit brought on behalf of the corporation - that alleges that the corporation has been hurt by the board's decision (in this case, to grant excessive pay to management).

Because shareholders generally do not make decisions on behalf of the corporation - the board is charged with making such decisions - the courts severely restrict shareholders' ability to proceed with a derivative suit. The most important procedural restriction is the "demand requirement." Under this requirement, shareholders first must "make demand" on the board to investigate the problem and take whatever steps are necessary to correct it. If there is a failure to make demand, the board can usually have the case dismissed. ${ }^{75}$ An exception is made, however, when shareholders can show that such a demand would be "futile."

If the shareholders make demand on the board to pursue the litigation (which, as the reader should recall, is against one or more members of the board itself), the board will take control over the lawsuit. ${ }^{76}$ The board will then almost always seek to dismiss the suit. ${ }^{77}$ If the board appears to have acted independently, and to have conducted a reasonable investigation of the allegations, the court will respect the board's decision to terminate the litigation and allow dismissal, ending the legal challenge to the board's compensation decision. Because demand almost always leads to the termination of the lawsuit, shareholders must claim that demand on the board is futile.

Establishing demand futility requires the plaintiff to offer "particularized facts" that create a reasonable doubt that (1) the directors are disinterested and independent and (2) the board's decision (approval of the compensation package) is not otherwise protected by the "business judgment rule" - the doctrine that shelters almost all board decisions from review. Creating a reasonable doubt about either can be difficult for shareholders to accomplish early in the litigation, especially because the plaintiff has not had the opportunity to conduct discovery.

\footnotetext{
75 See Randall S. Thomas and Kenneth J. Martin, Litigating Challenges to Executive Pay: An Exercise in Futility?, Wash U L Q 569, 579 (2001).

76 See id at $576 \& \mathrm{n} 33$.

77 See id at 576. The failure of the board to deal with the demand in good faith or to conduct a reasonable investigation could constitute a wrongful refusal of demand, giving control over the litigation back to the shareholders. See id at 576-77.

78 See id at 577.
} 
Consider the first approach: creating a reasonable doubt as to the independence of the board. To create such a doubt, one would generally need to show that the directors on the board have a direct financial interest in the compensation decision, or that they are beholden to the controlling person through personal or other relationships. ${ }^{79}$ Thus, by staffing the compensation committee with nominally independent directors, firms can make it practically impossible for shareholders to satisfy the demand-futility requirement by creating a reasonable doubt as to the independence of the board.

The second approach to establishing demand futility-creating a reasonable doubt that the board's decision is protected by the business judgment rule - requires the plaintiff to allege facts indicating that the board failed to fulfill either its "procedural due care" or its "substantive due care" duties. A board fails to fulfill its "procedural due care" duties by being uninformed. ${ }^{81}$ A board fails to fulfill its "substantive due care" duties by making an irrational decision and thereby committing "waste" or by making a "gift" unsupported by any consideration. However, the board can easily fulfill both types of duties. The board can satisfy its procedural duties by reading some materials and asking some questions. Similarly, the board can easily meet its substantive due process duties by coming up with a justification for the executives' salary. S3upport can be marshaled for even the most patently unreasonable plans.

If shareholders were to satisfy the demand futility requirementeither by showing that the board was not independent or that the board likely violated its duty of care - they might still face additional obstacles before they could get to trial. To begin, the board can appoint a "special litigation committee" of independent directors to advise the board on whether it is in the best interest of the firm to terminate the litigation. If the committee recommends dismissal, and the firm asks the court to dismiss the litigation, the court might well oblige.

In addition to (or after) arguing that the suit should be dismissed for failure to make demand or because a special committee recommends dismissal, the board might also move to dismiss the suit for failure to

79 It is not sufficient to show, for example, that an executive whose pay is being challenged owns a large percentage of the firm's shares and had personally selected the directors. See Aronson v Lewis, 473 A2d 805 (Del 1983)

80 See, for example, Marx v Akers, 666 NE2d 1034, 1036 (NY 1996) (rejecting shareholders' demandfutility claim, on the ground that the compensation committee consisted of independent directors).

81 See Brehm v Eisner, 746 A2d 244, 259-61 (Del 2000).

82 Id at 262-63.

83 Consider Loewenstein, 50 SMU L Rev at 214-15 (cited in note 6) (reporting that there have been no appellate court cases involving publicly traded firms affirming an order to reduce managerial compensation on the theory of gift or waste). 
state a legally recognized claim. If these fail, the board could move to dismiss through a summary judgment motion, arguing that the suit should be dismissed because plaintiffs have misinterpreted the law. And even once these procedural hurdles are overcome, the shareholders must actually win on the merits at trial and survive appeal-both daunting tasks.

b) Voting on option plans. Shareholders can also attempt to shape executive compensation when they vote on stock option plans. There are a number of situations in which shareholders might vote on an option plan. First, there are situations in which state corporate law or stock exchange rules require that shareholders vote on stock option plans. Under the corporate laws of some states-including New York-shareholders must approve all stock option plans, and under the corporate statutes of all states shareholders must approve stock option plans whenever the charter must be amended to increase the number of authorized shares. The stock exchange on which the firm's shares trade might also have rules requiring shareholder approval of certain kinds of stock option plans.

Second, firms that wish to deduct option compensation when an executive's total annual compensation exceeds $\$ 1$ million must put the option plan to shareholder vote. Section $162(\mathrm{~m})$ of the Internal Revenue Code disallows deductions of compensation paid to an executive in excess of $\$ 1$ million per year unless the compensation in excess off $\$ 1$ million is "performance-based." For an option plan to be "performancebased," it must receive shareholder approval.

However, even if shareholders were to vote on every stock option plan, such voting could not produce outcomes equivalent to arm's length bargaining. To begin, the stock option plans on which shareholders vote do not specify the design of a particular executive's compensation but rather set out general parameters for the use of stock options to compensate employees - such as the total number of options that can be issued under the plan. Thus, shareholders cannot use the vote to reject or approve a particular executive's pay package.

To be sure, shareholders could repeatedly refuse to approve the option plan until the CEO's compensation is acceptable. But the failure of shareholders to approve a plan is unlikely to make shareholders better off. The failure would force managers to modify the CEO's compensa-

84 Even if the corporate statute does not require a shareholder vote, the board of directors gains substantial protection from fiduciary duty suits if shareholders approve the stock option plan. See Randall S. Thomas and Kenneth J. Martin, The Determinants of Shareholder Voting on Stock Option Plans, 35 Wake Forest L Rev 46-51 (2000).

85 See id at 48 . 
tion and resubmit the option plan for shareholder approval at some future time. In the meantime, the absence of any option plan and the possibility that shareholders might again vote against the option plan could easily lead to the departure of good executives who wish to be compensated with options.

The cost of these departures to shareholders might be quite high and perhaps much higher than the gain from reducing the CEO's compensation. Thus, most of the shareholders voting on the plan are unlikely to oppose it unless the CEO's compensation is so high that the expected benefit of rejecting the plan exceeds the expected cost associated with the personnel instability that might result. In fact, shareholders rarely fail to approve these plans. In short, shareholder voting on option plans is unlikely to lead to optimal contracting over executive compensation.

\section{The MANAGerial Power APPROACH}

This Part puts forward the managerial power approach to executive compensation. Part II.A explains how managers with power use their power to influence the level and structure of their pay, and that managers with more power can be expected to do so to a greater extent. Managers with power are able to extract "rents"-value in excess of that which they would receive under optimal contracting - and managers with more power can extract more rents. Part II.B examines an important element of the managerial power approach - outrage costs and constraints. Rent extraction might give rise to outrage on the part of observers about whose views directors and managers care. This outrage can in turn impose costs on directors and managers, thereby discouraging the adoption of some arrangements favorable to managers. Part II.C examines another important element of the managerial power approach"camouflage" - managers' attempts to hide, obscure, and justify various aspects of their compensation in order to reduce outrage.

86 In some cases shareholders offer nonbinding (precatory) resolutions requesting more specific limitations on executive compensation. See Brian R. Cheffins and Randall S. Thomas, Should Shareholders Have a Greater Say over Executive Pay?: Learning from the U.S. Experience, 1 J Corp L Stud 227-315 (2001). These resolutions have no legal effect and usually attract very few votes.

One might infer from the failure of these resolutions that institutional shareholders believe there is no problem with executive compensation. But this is unlikely to be the right inference. We agree with Kahan and Rock that institutions have decided to focus their limited power on certain problems and not others. See Marcel Kahan and Edward B. Rock, How I Learned to Stop Worrying and Love the Pill: Adaptive Responses to Takeover Law, $69 \mathrm{U}$ Chi L Rev 871, 898 (2002). The institutions seem to have made the judgment that it would be more important for them to address the problems of entrenchment and takeover defenses rather than that of executive compensation. This "bargain" might make sense given the pragmatic considerations of institutional investors, but it hardly indicates that executive compensation arrangements are optimal. 
Part II.D discusses the role of compensation consultants and how they can be used to camouflage rent extraction. Part II.E discusses how, even though the use of options might itself be beneficial to shareholders, the particular design of option compensation plans might deviate from that suggested by optimal contracting, due to managerial power. Finally, Part II.F considers an alternative explanation for deviations from optimal contracting - that they are caused by boards' tendency to conform to norms; we argue that, although norms are likely to play a role in executive compensation practices, they cannot by themselves provide a full explanation for the development and persistence of arrangements that deviate considerably from what would be expected under optimal contracting.

\section{A. Managerial Power and the Extraction of Rents}

Like the optimal contracting approach, the managerial power approach starts with recognition of the shareholder/management agency problem. However, under the managerial power approach executive compensation is not seen solely as a remedy to this agency problem. Rather, certain features of executive compensation are seen as part of the problem itself. Under the optimal contracting approach, the board designs compensation arrangements exclusively for the purpose of alleviating the agency problem between shareholders and executives. In contrast, under the managerial power approach part of the agency problem is that executives use their compensation to provide themselves with rents.

The managerial power approach picks up with our analysis of the limitations of the optimal contracting approach. That analysis indicates that corporate managers have considerable power. Even nominally independent directors are often connected to executives by bonds of interest, collegiality, or affinity. These directors might rise up and displace a particularly poorly performing CEO. However, if the CEO is performing adequately, they generally will be inclined to defer to and support the CEO's judgment. Given the considerable influence of the CEO and the CEO's management team over the board, bargaining over executive compensation does not usually approach the arm's length ideal. Rather, executives frequently use their power to increase their compensation, and directors cooperate with management at least to some extent.

The excess pay that executives are able to extract because of their positional power constitutes rents. Specifically, the amount of rents that an executive extracts is the excess of the pay obtained by him over what he would have received under a contract that maximizes shareholder value. Because rent extraction is associated with managerial power, the 
managerial power approach suggests that there is a correlation between managerial power and rents. Executives generally have at least some power and therefore can extract at least some rents, but the particular characteristics of a firm, especially its ownership and board structure, give its executives more or less power. Under the managerial power approach, the greater the CEO's power, the higher the rents will tend to be.

The power of the CEO will depend in large part on the ownership structure of the firm. The more shares owned by the CEO, the greater will be her influence on director elections and her ability to thwart or discourage a hostile takeover attempt. The more shares owned by unrelated parties, the less will be the CEO's influence on director elections and the more vulnerable the CEO will be to a hostile takeover attempt. Thus, the power of the CEO will tend to increase with the percentage of shares he owns, and will tend to decrease with the percentage of shares owned by outside blockholders.

The CEO's power will also depend on the organization and composition of the board. The CEO's power will depend on the number of inside directors and the number of independent directors. Also critical is the number of directors over whom the CEO has some kind of influence. For example, an independent director might follow a CEO's wishes because he is a longtime friend of the CEO or because he is grateful that the CEO has placed him on the board. And because a classified board makes a hostile takeover more difficult, a CEO's power will tend to be greater if the board is classified.

In Part III.G, we discuss the correlation between managerial power and rent extraction in more detail, as well as present evidence of such a correlation. For now, however, it is worth pointing out that this aspect of the managerial power approach can explain much of what is observed in the world of executive compensation.

It is important to emphasize that the cost to the shareholders resulting from the extraction of rents might well be higher than the amount of the rents themselves. To the extent that rent extraction involves efficiency costs - due, in particular, to the adoption of inefficient compensation arrangements - the shareholders' losses will be larger than the rents extracted by managers.

Although our discussion of power and rent extraction often focuses on the CEO, we should point out that other officers are also likely to receive rents. Although in many companies power is concentrated in the hands of the $\mathrm{CEO}$, in some companies power might be distributed among two or more officers (say, the CEO and the president), each of whom has the power to extract rents. And even when the CEO has all of the power, the CEO might use his power not only to extract rents for 
himself, but also to extract rents for high-ranking members of his management team. Our discussion regarding rent extraction will refer to the rents captured by the powerful CEO and, in certain cases, by other officers as well.

The managerial power approach is in the spirit of the economics literature that focuses on the power certain agents obtain in organizations and those agents' ability to use this power to extract rents. ${ }^{88}$ Unfortunately, financial economists working in the particular context of executive compensation have largely followed the optimal contracting approach and paid little attention to the role of managerial power.

\section{B. "Outrage" Costs and Constraints}

The managerial power model does not imply that there are no constraints at all on compensation and the rents that executives can capture. At some point, even directors who have been appointed by the CEO and feel loyal to him will refuse to approve a compensation package, or shareholders might seek to replace the CEO. An important factor affecting executives' ability to increase their compensation is the amount of "outrage" their proposed pay package would create. If an executive's compensation arrangement goes far beyond what could be justified under optimal contracting and is perceived that way by outsiders, those outsiders might become angry and upset. If this outrage is sufficiently widespread and intense, it limits the extent to which compensation can be increased in a number of ways.

First, outrage can affect the ability of the CEO to get the board's approval of his pay package. We have argued that boards do not, as optimal contracting theorists believe, secure compensation arrangements that are as close to optimal as reasonably possible. That is, the need to get the board's consent to executives' pay packages does not produce the same outcome as arm's length bargaining. However, even though boards are willing to give executives more favorable treatment than

87 A CEO might provide rents to his management team in order to narrow the gap between his compensation and theirs. Narrowing the gap might make the CEO's rent extraction less noticeable to outsiders and thereby reduce "outrage costs," the subject of the next section. Narrowing the gap might also reduce the other officers' resentment, if any, of the CEO's high pay, and thereby facilitate a better working relationship between the officers and the CEO. Finally, in cases where the CEO and other officers are friends, the CEO might provide the officers with rents on account of their friendship.

88 See, for example, Jack Hirshleifer, Conflict and Rent-Seeking Success Functions: Ratio vs. Difference Models of Relative Success, 63 Pub Choice 101, 101-12 (1989); Jack Hirshleifer, Competition, Cooperation, and Conflict in Economics and Biology, 68 Am Econ Rev 238, 238-43 (1978); Raghuram G. Rajan and Luigi Zingales, Power in a Theory of the Firm, 113 Q J Econ 387, 387-432 (1998); Raghuram G. Rajan and Luigi Zingales, The Firm as a Dedicated Hierarchy: A Theory of the Origin and Growth of Firms, $116 \mathrm{Q}$ J Econ 805, 817-18 (2001).

89 Noteworthy exceptions are the studies listed in note 6. 
what they would get under arm's length bargaining, there are obviously limits to how far they would be willing to go. Whether a board is willing to approve a particular compensation arrangement depends at least in part on the extent to which the arrangement can be expected to generate outrage. At some point, directors would be expected to draw the line because the outrage produced by going further would be too costly for them. In other words, outrage imposes constraints through its effect on the board.

Outrage might produce various social and reputational costs to directors. Professional reputation is very important to outside directors who generally do not join a board solely for the pay. Many outside directors join boards for the prestige and connections that the posts give them. ${ }^{90}$ Hence, outside directors would be loath to approve a compensation plan that would embarrass them or compromise their reputations. Outside directors would be concerned about how such plans might be viewed by the media or various social or professional groups whose opinions are important to the directors. As a result, they would support management only insofar as the compensation proposal does not impose too much outrage cost. In certain cases, the same fear of embarrassment that might discourage directors from approving an outrageous compensation package might also affect managers directly and thereby discourage them from seeking such a package in the first instance.

In addition, outrage might affect the market forces discussed earlier that could, in theory, limit executive compensation. These forces, we have argued, are usually not sufficiently strong to prevent substantial deviations from optimal contracting. However, outrage might strengthen one or more of the various market forces in a way that makes them more of a constraint.

Consider the market for corporate control. Although the reduction in shareholder value due to excessive compensation is unlikely by itself to trigger a challenge to managers' control, outrageous increases in compensation might increase significantly the likelihood of such an attempt. For example, institutional investors might view such compensation as a signal that the executives or directors are especially insensitive to shareholder interests and thus be less willing to support the incumbents in a control contest. If support for management weakens, a contest for control, through either a proxy battle or a takeover bid, might be more likely to arise.

It is worth emphasizing that for outrage to impose significant costs it must be sufficiently widespread among the relevant groups of people.

90 See Lorsch and MacIver, Pawns or Potentates? at 23-31 (cited in note 24). 
Although a small group of observers-be they sophisticated market participants or researchers - might identify a compensation scheme as involving an especially egregious amount of rents, the resulting outrage by itself would not necessarily generate significant costs for the directors and executives. For executives or directors to be adversely affected in a material way the outrage must be felt by relevant groups-such as institutional investors en masse, the media, and/or social and professional groups - about whose views the executives and directors care. Therefore, whether significant outrage costs can be expected to arise would depend on the extent to which rent extraction is clearly apparent to outsiders, not just (or even mainly) upon how much rents are extracted.

A testable prediction of the influence of outrage costs is that criticism by outside observers will have an effect on executive compensation. Evidence consistent with this prediction is in fact provided by recent studies. One study finds that firms receiving negative coverage of their executive compensation policies in Business Week, Forbes, Fortune, and Institutional Investor during the years 1992-1994 experienced smaller increases in total compensation than other firms during the years 1993-1994. ${ }^{91}$ These firms also subsequently increased the sensitivity of cash compensation to firm performance. Another study provides evidence that shareholder precatory resolutions criticizing executive compensation as excessive lead to some reduction in executive pay-even

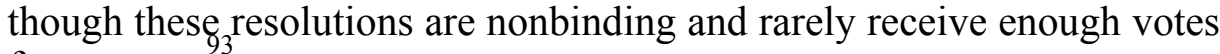
for passage.

Another testable implication is that designers of compensation arrangements will seek to avoid or reduce outrage by designing, packaging, and justifying compensation arrangements in a way that camouflages managers' rents and conceals their magnitude. This brings us to the role of camouflage under the managerial power approach.

\section{The Critical Role of "Camouflage"}

As we have discussed, excessive compensation will not by itself impose significant outrage costs. A large amount of outrage will occur

\footnotetext{
91 See Marilyn F. Johnson, Susan Porter, and Margaret B. Shackell, Stakeholder Pressure and the Structure of Executive Compensation at 4, working paper (1997), available online at $<\mathrm{http}: / /$ papers.ssrn.com/id=41780> (visited May 4, 2002) .

92 Id.

93 Randall S. Thomas and Kenneth J. Martin, The Effect of Shareholder Proposals on Executive Compensation, 67 U Cin L Rev 1021, 1065 (1999). But see Johnson, et al, Stakeholder Pressure at 4 (cited in note 91) (reporting that shareholder proposals do not have a significant effect on either the amount of executive compensation or its sensitivity to performance).
} 
only if there is widespread recognition that the level of compensation does not result from a contract designed to maximize shareholder value, but rather reflects a large extraction of rents. Thus, outrage costs depend on the extent to which the rent extraction can be easily and distinctly identified. A large extraction of rents will not cause the executives or directors harm if it can be dressed, packaged, or hidden-in short, camouflaged - so that it is not readily apparent as such.

Accordingly, under the managerial power approach, managers will prefer compensation structures and processes that enable the extraction of rents to be camouflaged as optimal contracting. As we discuss below, outrage costs and constraints and the resulting camouflage motive might explain why firms rely so heavily on compensation surveys and consultants. In Part III, we will show that many other aspects of existing compensation practice can be explained by considerations of camouflage.

One might ask how any observer can tell that rent extraction is taking place if it is camouflaged. To be sure, rent extraction will sometimes be undetectable by outside observers. However, the presence of camouflage does not imply that rent extraction will be unidentifiable to every observer. As noted earlier, camouflage is successful as long as it prevents rent extraction from being easily identifiable to certain large groups of outside observers. Thus, it is in no way a contradiction for a researcher to view a certain compensation practice as being likely to include camouflaged rents. Such a judgment simply reflects the conclusion that the researcher has found to her own satisfaction that the compensation package or program is likely not to serve shareholders' interests, but rather to represent rent extraction.

A testable implication of the managerial power approach is that, when compensation arrangements and practices deviate from those that are optimal, they tend to do so in a way that minimizes the amount of managerial rents easily visible to outsiders. As will be seen in Part III, this testable prediction appears to be borne out by the way in which actual practices deviate from what would be expected under optimal contracting.

\section{Compensation Consultants and Camouflage}

U.S. public companies typically employ outside consultants to provide input into the executive compensation process. ${ }^{94}$ Their use can be

94 See John M. Bizjack, Michael L. Lemmon, and Lalitha Naveen, Has the Use of Peer Groups Contributed to Higher Levels of Executive Compensation? at 10, 44, working paper (2000), available online at $<\mathrm{http}: / /$ papers.ssrn.com/id=252544> (visited May 4, 2002) (reporting that at least 65 percent of firms use compensation consultants). 
explained within the optimal-contracting framework in the following way: Compensation consultants contribute to improving executive pay practices for two distinct reasons. First, they contribute expertise on the design of compensation packages. Second, they conduct compensation surveys and provide access to industry pay data that would not be shared directly among companies. ${ }^{95}$ These data, in turn, might be used to improve the design of compensation packages.

Although we agree that compensation consultants can and sometimes might play such a useful role, we think it is important to understand that they also might play a role in camouflaging rent. In particular, the process through which pay consultants are retained-and some evidence regarding their use-suggest that managers use compensation consultants primarily to justify executive pay, rather than to optimize it.

The compensation consultant has a strong incentive to please the CEO. Typically, compensation consultants are hired through a company's human resources department, and anecdotal evidence suggests that some CEOs are heavily involved in the process. Even if the CEO is not normally involved in the selection of the compensation consultant, the threat of his involvement the next time-should the consultant suggest a package not to his liking - is likely to keep the consultant in line. Moreover, executive pay consultants often work for consulting firms that have other, larger assignments with the hiring company. This tends to undermine their objectivity.

Pay consultants can gain the favor of the CEO by generating a mass of compensation data that can be used to justify "objectively" the desired pay plan. For example, they can design surveys to focus on comparative data that help make the case for higher pay. It is widely understood that the methodology of compensation consultants and boards in devising compensation plans results in a "ratcheting up" of salaries.

Once the compensation consultant has collected the "relevant" comparative data on peer compensation, the board almost always de-

95 These data are provided in summary form only, of course. Firms participate in compensation surveys with the understanding that individual firm data will be kept confidential by the consultant.

96 For an insider's account of the use of compensation consultants to justify executive pay, see Crystal, In Search of Excess (cited in note 6).

97 See id at 220.

98 See id at 219 (suggesting that employee benefits and other assignments often produce more revenue for a consulting firm than the executive compensation consulting assignment).

99 See id at 221 (describing the different rationalizations used by CEOs for pay increases).

100 See Murphy, Executive Compensation at 2517-18 (cited in note 2); Crystal, In Search of Excess at 219 (cited in note 6). 
cides that it wants the firm to be at the fiftieth percentile of CEO salary or higher. Bizjack, Lemmon, and Naveen report that in a review of the 1997 compensation committee reports of one hundred firms in the S\&P 500 index, ninety-six firms indicated that they use peer groups in determining management compensation, and that the "vast majority" of firms that use peer groups set compensation at or above the fiftieth percentile of the peer group. ${ }^{02}$ This leads to an ever increasing ratchetingup of compensation, including the compensation of poorly performing executives. ${ }^{103}$ Examining approximately 1500 publicly traded firms during the period 1992-1998, Bizjack, Lemmon, and Naveen found that CEOs who are paid below the median amount receive much larger increases (in both percentage and absolute terms) than CEOs who are paid above the median, even when these firms have worse accounting and stock price performance.

Wade, Porac, and Pollack provide some evidence that companies use pay consultants and surveys strategically in justifying executive compensation to outsiders. They find that companies that pay their CEOs larger base salaries and firms with more concentrated and active outside ownership are more likely to cite the use of surveys and consultants in justifying executive pay in their proxy reports to shareholders. The authors also find that accounting returns are emphasized when they are high and that market returns are de-emphasized when they are volatile. ${ }^{105}$ These findings are again consistent with a view that executives use compensation consultants to generate and justify higher compensation.

\section{E. The Design of Stock Option Plans: The Devil Is in the Details}

During the 1980s and 1990s, executive stock options became an increasingly important element of corporate compensation schemes. The increasing use of options has been a primary factor driving the ten-

\footnotetext{
101 See Crystal, In Search of Excess (cited in note 6) (reporting that 35 percent of firms surveyed aimed to pay at the seventy-fifth percentile, while 65 percent aimed for fiftieth percentile pay).

102 Bizjack, Lemmon, and Naveen, Has the Use of Peer Groups Contributed to Higher Levels of Executive Compensation? at 2 (cited in note 94).

103 See Tully, Raising the Bar, Fortune at 272 (cited in note 6).

104 See James B. Wade, Joseph F. Porac, and Timothy G. Pollock, Worth, Words, and the Justification of Executive Pay, $18 \mathrm{~J}$ Org Beh 641, 657 (1997).

105 See id at 658.

106 Murphy reports that option grants in manufacturing firms increased from 27 percent to 36 percent of total compensation between 1992 and 1996 alone. See Murphy, Executive Compensation at 2490 (cited in note 2). Yermack finds that, on average, option awards accounted for 20 percent of CEO compensation in 1984 and 30 percent in 1991. See David Yermack, Do Corporations Award CEO Stock Options Effectively?, 39 J Fin Econ 237, 238 (1995).
} 
fold increase in CEO pay-for-performance sensitivity over the last two decades.

This trend was responsive to the longstanding demand of management experts and shareholder activists for a shift away from fixed compensation to performance-responsive pay. Another factor in the rise of options was the enactment of Section $162(\mathrm{~m})$ of the Internal Revenue Code, which disallows a deduction for executive compensation paid to an executive in excess of $\$ 1$ million per year unless the excess compensation is "performance-based."

The managerial power approach does not question the desirability of using options to compensate executives. Options provide managers with greater incentive to create shareholder value, and thus the use of options in executive compensation might well be beneficial to shareholders. Rather, the managerial power approach focuses on whether the magnitude and design of a particular option-based pay package is close to that which would arise under optimal contracting.

In other words, the question is not whether a particular option plan makes shareholders better or worse off than no option plan, but whether the "details" of the plan that is adopted - the number of options granted to the executives and, more importantly, the way in which those options are structured - are optimal. The devil is in these details, which are very important. A badly designed option plan might produce significantly less value for shareholders than a plan constructed to maximize shareholder wealth.

107 Insensitivity of executive compensation to firm performance reportedly was one criterion employed by T. Boone Pickens's United Shareholders of America in its 1986-1993 campaign to improve corporate governance. See Deon Strickland, et al, A Requiem for the USA: Is Small Shareholder Monitoring Effective?, 40 J Fin \& Econ 319, 320 (1996).

108 See note 17.

109 There is an extensive literature on the design of optimal compensation arrangements and related issues. Recent contributions to this literature include Jorge G. Aseff and Manuel S. Santos, Stock Options and Managerial Optimal Contracts, working paper (2001), available online at $<$ http://www.cob.asu.edu/pubs/files/aseff-santos.pdf> (visited Apr 27, 2002); John Core and Wayne Guay, When Contracts Require Risk-Averse Executives to Hold Equity: Implications for Option Valuation and Relative Performance Valuation, working paper (2001), available online at $<\mathrm{http} / / /$ papers.ssrn.com/id=271123> (visited May 4, 2002); Tom Nohel and Steven Todd, Executive Compensation, Reputation, and Risk-Taking Incentives, working paper (2001); Tom Nohel and Steven Todd, Optimal Compensation for Risk-Averse Executives with Career Concerns, working paper (2001); Yisong S. Tian, Optimal Contracting, Incentive Effects, and the Valuation of Executive Stock Options, working paper (2001); Lisa K. Meulbroek, The Efficiency of Equity-Linked Compensation: Understanding the Full Cost of Awarding Executive Stock Options, 30 Fin Mgmt 5 (Summer 2001); Frank Moers and Erik Peek, Managerial Risk Aversion and Executive Compensation: Measurement Issues and an Empirical Test, working paper (2000) (on file with authors); Tom Nohel and Steven Todd, Executive Compensation, Managerial Risk Aversion, and the Choice of Risky Projects, working paper (2000) (on file with authors); George Baker, Distortion and Risk in Optimal Incentive Contracts at 22, working paper (2000), available online at $<$ http://gsbwww.uchicago.edu/research/workshops/wto/PDF/Distortion_and_Risk_15.pdf $>$ (visited May 4, 
Interestingly, the only recent study that considers the effect of options on shareholder value suggests that the option plans designed by boards do not reflect optimal contracting. In particular, the study examines publicly traded U.S. firms between 1992-1997. It finds that boards give CEOs too many options: the marginal incentive benefit of the last option is less than the cost to shareholders. In other words, shareholder value would increase if the number of options held by CEOs were reduced, holding everything constant. ${ }^{110}$ Thus, the most relevant empirical data suggest that the design of option programs is consistent with the presence of managerial power and rent extraction.

We will focus on the design of option plans in Part III, where we argue that many of the most prominent features of option grants - such as the use of non-indexed options, at-the-money strike prices, and the lack of restrictions on unwinding incentives - are better explained by the managerial power approach, and thus that managerial power likely plays a significant role in the design of option plans and practices.

\section{F. A Note on Conforming to Norms}

In the last ten years there has been much interest among legal scholars in the existence and evolution of "norms" and their effect on behavior in a wide variety of contexts. Recently, legal scholars have focused their attention on the effect of norms in the context of corporate law and corporate governance. ${ }^{12}$ It is thus natural to ask whether

2002); Li Jin, CEO Compensation, Diversification and Incentives at 25, working paper (2000), available online at $<$ http://papers.ssrn.com/id=254260 $>$ (visited Apr 27, 2002).

110 Michel A. Habib and Alexander P. Ljungqvist, Firm Value and Managerial Incentives at 17, working paper (2000), available online at $<$ http://papers.ssrn.com/id=252375> (visited May 5, 2002).

111 The only other study focusing exclusively on options also suggests that option plans might not be designed optimally. An analysis of companies that adopted executive stock option plans between 1978 and 1982 determined that cumulative abnormal returns declined subsequently for two-thirds of the sample, that ROA declined absolutely and adjusted for industry, that R\&D expenditure decreased, and that perquisite consumption increased. See Richard A. DeFusco, Robert R. Johnson, and Thomas S. Zorn, The Association between Executive Stock Option Plan Changes and Managerial Decision Making, 20 Fin Mgmt 36, 40 (1991). There have been a number of other studies that find that the use of options increases stock price and cash flow volatility. See, for example, Richard A. DeFusco, Robert R. Johnson, and Thomas S. Zorn, The Effect of Executive Stock Option Plans on Stockholders and Bondholders, 45 J Fin 617, 626 (1990); Anup Agrawal and Gershon N. Mandelker, Managerial Incentives and Corporate Investment and Financing Decisions, 42 J Fin 823 (1987); Shivaram Rajgopal and Terry Shevlin, Early Evidence on the Informativeness of the SEC's Market Risk Disclosures: The Case of Commodity Price Risk Exposure of Oil and Gas Producers, 74 Acct Rev 251 (1999); Catherine Schrand and Haluk Unal, Hedging and Coordinated Risk Management: Evidence from Thrift Conversions, 53 J Fin 979 (1998); Peter A. Tufano, Who Manages Risk?: An Empirical Examination of Risk Management Practices in the Gold Mining Industry, 51 J Fin 1097 (1996).

112 See, for example, Melvin A. Eisenberg, Corporate Law and Social Norms, 99 Colum L Rev 125392 (1999), and the articles appearing in the 2001 University of Pennsylvania Law Review Symposium on Norms and Corporate Law. 
norms - and, in particular, the pressure to conform to norms - might play a role in executive compensation.

In legal scholarship, the term "norms" has been used generally to refer to nonlegal rules of conduct and behavior. Some norms simply reflect patterns of behavior that have arisen and tend to persist primarily because actors observe one another behaving in a particular way and believe that there is a potential cost to deviating from that behavior. Suppose, for example, that every year the partners of $A B C$ law firm use firm funds to give each of their secretaries a Christmas bonus. Beth, a partner at $\mathrm{ABC}$ law firm, learns that every other partner at $\mathrm{ABC}$ law firm is going to give his or her assistant $\$ 500$ in cash. She must decide how much to give her assistant. If she gives less than this amount, her assistant might feel insulted. If she gives more, other partners might feel obligated to give a larger bonus next year lest their assistants feel insulted, and this may cause the other partners to resent Beth for "wasting" the firm's funds and reducing their profits. Thus, Beth will have an incentive to stick to the established pattern of giving assistants a Christmas bonus of $\$ 500$ in cash.

The pressure to conform probably plays an important role in executive compensation. At any given point in time, this pressure is likely to affect both the amount and structure of executive compensation arrangements recommended by compensation committees and approved by boards. As we noted earlier, compensation committees recommend pay arrangements based in large part on the compensation packages they see at other firms. There is clearly a desire on the part of such committees and the board to conform to "the norm," or at least to be seen as conforming to the norm.

At a minimum, the desire to conform makes any movement from one equilibrium to another much slower and more gradual. Compensation committees' preference for conforming to the "norm" and fear of deviating substantially from it means that the evolution of compensation arrangements will take more time. Thus, whatever the nature of the current equilibrium, movement from it will be "sticky" due to the desire to conform to established patterns.

The main point we wish to emphasize is that the desire to conform to established patterns cannot provide a basis for a full account of executive compensation. The stickiness arising from the tendency to conform implies only that movement from one equilibrium to another will be very slow. It cannot explain why we are in a particular equilibrium to begin with. More importantly, given that patterns of executive compensation change over time, norms cannot tell us much about the new equilibrium to which we are heading, however slowly. To provide a full ac- 
count of executive compensation, norms must be combined with another theory such as optimal contracting or managerial power.

A theory combining norms with the optimal contracting approach would predict that the evolution of executive compensation over time, although slowed down by the tendency to follow established practices, would be largely shaped by the forces of optimal contracting. That is, as changing circumstances make the existing equilibrium suboptimal, boards induced by market pressure will move toward what would be the new optimal arrangement. Although the stickiness introduced by the desire to conform would prevent adjustment from being instantaneous, the forces of optimal contracting should be sufficiently strong to ensure that executive compensation does not deviate for a long time from what participants recognize to be the optimal arrangement.

In contrast, the managerial power approach predicts that the evolution of executive compensation over time is shaped at least in part by the desire of executives to extract more rents from their firms. When changing circumstances create an opportunity to extract additional rents - either by changing outrage costs and constraints or by giving rise to a new means of camouflage - managers will seek to take full advantage of it and will push firms toward an equilibrium in which they can do so. However, the stickiness due to norms will slow this movement somewhat.

Thus, even though we recognize the importance of the pressure to conform we need another theory (or other theories) to explain why we are at the current equilibrium and what forces will move us to the next as circumstances change. The question is whether optimal contracting is the only other theory needed, or whether managerial power must also be taken into account.

\section{EVIDENCE BETter EXPLAINED BY THE MANAGERIAL POWER APPROACH}

This Part discusses important elements of the empirical evidence on executive compensation that are difficult to understand within an optimal contracting framework but that are consistent with and can be explained by the managerial power approach. Some of the compensation practices and patterns we consider-for example, the absence of any significant attempt by firms to design option plans that at least partly filter out stock price gains due to industry or general market trends-have long puzzled researchers adhering to the optimal contracting approach. Others have so far received little attention in the executive compensation literature (for example, managers' broad freedom to unwind incentives and to choose the time of such unwinding). 
We believe that the managerial power approach can better explain these and other features of the executive compensation landscape. But accepting our thesis does not depend on accepting our interpretation of each and every one of these practices and patterns. What is important is the picture emerging from these patterns and practices in the aggregate. In the aggregate, we suggest, these practices and patterns provide a solid basis for concluding that managerial power is likely to play a significant role in the design of executive compensation.

\section{A. Rewarding Executives for General Market Rises}

This section examines a compensation practice that has long been regarded as odd by optimal contracting theorists - the practice of compensating executives for increases in firm value and the stock price that are not in any way due to their own efforts. For example, conventional options reward managers for absolute increases in the share price even when those increases are due solely to factors beyond managers' control, such as interest rate declines.

Compensation dollars could be much better targeted if executives received these dollars only to the extent that the increase in their firm's share price was due to firm-specific performance, rather than sector or general market performance. To be sure, it is not feasible to filter out perfectly the effects of sector or general market trends. As will be explained, however, there are a number of ways of limiting managers' windfalls from that part of the stock price increase that would have occurred in any event. Some of these approaches involve "indexing" the exercise price of options. For example, as Alfred Rappaport has recently proposed in the Harvard Business Review, stock options could be designed with an exercise price that rises or falls with either sector or broader market movements. ${ }^{13}$ There are other approaches as well. For example, the vesting of options could be made dependent on the share price exceeding a certain benchmark. "Moderate" versions of such vesting schemes might bar vesting only if the firm is one of the worst performing firms in its sector (say, in the bottom 20 percent). Each of the possible alternative mechanisms would tie an executive's reward more closely to firm-specific performance, over which he has considerable control.

Yet, as this Part explains, firms almost never employ any version (however moderate) of what we call "reduced-windfall options"-

\footnotetext{
113 See Alfred Rappaport, New Thinking on How to Link Executive Pay with Performance, Harv Bus Rev 91, 101 (Mar-Apr 1999). See also Mark A. Clawson and Thomas C. Klein, Indexed Stock Options: A Proposal for Compensation Commensurate with Performance, 3 Stan J L, Bus \& Fin 31, 31-50 (1997).
} 
options with features (such as an indexed exercise price) that screen out effects beyond managers' control. Optimal contracting theorists have tried to explain the failure of all but a handful of companies to employ reduced-windfall options but, as we will see, their efforts have not been very successful. The widespread failure of firms to adopt mechanisms that filter out sector and market effects from managers' option compensation has led some prominent researchers in the field of executive compensation to conclude that "the near complete absence [of such mechanisms] seems to be a puzzle." failure can be explained under the managerial power approach.

1. The suboptimality of rewarding managers for market rises.

The optimal principal-agent contract should compensate the agent based on the achievement of objectives within the scope of his control. Since managerial effort essentially is unobservable and accounting results are noisy and fail to reflect the current value of growth opportunities, the share price of a firm provides a useful tool for evaluating executive performance.

However, compensation based on absolute share price performance rewards managers even when the managers' efforts have not contributed to the share price increase. In particular, the share price increase might be driven solely by factors external to the firm - such as changes in the economy that benefit the firm's industry or interest rate declines that benefit the market as a whole. One study of U.S. stock prices over a recent ten-year period reports that only 30 percent of share price movement reflects corporate performance, ${ }_{115}$ with the remaining 70 percent driven by general market conditions. ${ }^{115}$ Because of such external factors, even managers who perform poorly-and whose actions therefore make shareholders relatively worse off - can profit when their compensation is linked to changes in the absolute share price.

To be sure, when managers' compensation is linked to the absolute share price, even managers who add value will not profit if their firm's stock price nevertheless declines because of changes in the economy or the firm's sector. But such negative shocks are unlikely to hurt managers as much as positive shocks will benefit them. At worst, negative shocks make the options worthless. Positive shocks, on the other hand, can increase the value of the options by an unlimited amount. Thus, on an ex-

114 Brian J. Hall and Jeffrey B. Liebman, Are CEOs Really Paid Like Bureaucrats?, 113 Q J Econ 653, 683 n 34 (1998).

115 See Simon Patterson and Peter Smith, How to Make Top People's Pay Reflect Performance, Sunday Times $\S$ Bus at 12 (Aug 9, 1998). 
pected-value basis, the contribution of external market and sector forces to the value of the options is always positive.

From shareholders' perspective, an option plan should be designed to maximize incentives given the amount of dollars spent, or to achieve a certain amount of incentives at the lowest possible cost. When managers are rewarded for market- and sector-wide price movements that have nothing to do with their efforts, the money is poorly spent. This raises the possibility that the firm could either create the same incentives for less money or use the same amount of money to create even more powerful incentives.

The latter possibility is worth spelling out. If the firm gives the managers one thousand options to buy stock at the current market price of one hundred dollars, some of the expected value of the options - and therefore some of the expected cost of the options to other shareholders-comes from the fact that the stock price might increase for reasons having nothing to do with the managers' efforts but rather, say, because of unexpected reductions in interest rates. To the extent industry- and market-wide effects boost the stock price, the manager will be "rewarded" for these increases when he exercises the options and shareholders will pay for this reward, even though this reward has no effect on the manager's incentives.

If we could design a scheme to remove or reduce the undeserved reward component of the option's value - that is, create a reducedwindfall option-we could at the same cost give the manager a larger number of differently structured options that would provide better incentives by linking the payoff more closely to the manager's efforts. Thus, significant benefits could be obtained from "reduced-windfall" schemes that remove some or all of the reward that has nothing to do with the manager's contribution to the stock price increase.

\section{Alternative ways of designing reduced-windfall options.}

There are a number of ways that windfall gains from options could be reduced. One approach that has received a great deal of support from academics and other commentators is that of "indexing" the exercise price of the option to the performance of the sector or the market to filter out changes in the stock price that are not due to the manager's efforts. To the extent the indexed option could not be used to capture the expected increase in the stock price due to non-firm-specific effects, its expected value - and its expected cost to shareholders - would be lower. We first consider indexing, and then examine other methods of reducing option-based windfalls. 
a) Indexing. By giving managers options that reward them only for increases in stock price that are firm-specific and thus more likely to result from the managers' own efforts, a firm could, at the same cost, give more options to the managers and thereby increase their reward for creating value themselves. This in turn should induce more effort and lead managers to do more things that are unpleasant for them but good for shareholders, such as firing loyal but incompetent subordinates.

Returning to our example, one might be able to give - at the same expected cost as one thousand conventional options-1500 options whose strike price is $\$ 100$ (the current market price) multiplied by, say, a market index. Under such a scheme, if the market has risen 30 percent since the options were granted, the exercise price would be $\$ 100 \mathrm{x}$ (1.30) or $\$ 130$. Although such a scheme would have the same expected cost to the firm, it would provide stronger incentives. Of course, the index need not reflect the average performance of the market as a wholeit could reflect the average performance of firms in the same industry. Using this narrower index would screen out not only broad market effects, but also effects associated with the firm's industry.

We should emphasize that standard indexing of exercise prices (indexing either to the market average or to the average of a basket of peer firms) is not the only possibility. Suppose, for example, that one opposes indexing options to the average performance of peer firms because one believes that there are problems specific to the firm, not attributable to the CEO, that will limit the firm's performance in the short run. Or suppose the firm has no such problems but one is concerned that the CEO will have insufficient incentive to generate value if, in the middle of the vesting period, the CEO finds his firm ranked at the bottom of the industry and believes there is little he can do to bring his options into the money. A person with these concerns might prefer a more "moderate" form of indexing where the exercise price is indexed not to the average performance of the industry (or the wider market) but to a certain frac-

\footnotetext{
116 See, for example, Shane A. Johnson and Yisong S. Tian, The Value and Incentive Effects of NonTraditional Executive Stock Option Plans, 57 J Fin Econ 3, 25-26 (2000) (arguing that indexed options create more powerful incentives per dollar value than traditional options). For a detailed analysis of the incentive effects and valuation of indexed options, see Shane A. Johnson and Yisong S. Tian, Indexed Executive Stock Options, 57 J Fin Econ 35 (2000).

117 For an analysis suggesting that indexed options could not screen out all market or industry effects, see Lisa K. Meulbroek, Executive Compensation Using Relative-Performance-Based Options: Evaluating the Structure and Costs of Indexed Options at 1-3, working paper (2001), available online at $<$ http://papers.ssrn.com/id=281028 $>$ (visited May 5, 2002) (contending that an option with an exercise price tied to a market or industry index does not completely filter out market or industry effects, and offering an alternative mechanism designed to do so).
} 
tion of it. Alternatively, one could tie the exercise price to the performance of the companies in say, the bottom quartile of the industry.

Note that such full or partial indexing may lead to the exercise price being lower than the grant-date market price. It is worthwhile, therefore, to consider the case in which one wants the exercise price never to fall below the grant-date market price. In such a case, one could still index the exercise price but do so only on the upside. This could be done by using an exercise price that is the greater of (a) the grant-date market price and (b) the index-adjusted price. Any index could be used. Therefore, one could tie the exercise price to the performance of the broader market, the industry, or some other set of firms, using average performance or any other metric, such as percentiles. The only situation in which this semi-indexed scheme would yield different results than a conventional option is that in which the index is in positive territory. In such cases, the payouts would be lower. However, by employing the semi-indexed scheme, the expected savings from not rewarding the manager for changes in the sector and the market beyond his control could be used to increase the number of options given at the grant date and thereby boost performance incentives.

We want to stress that it is not our intention here to reach firm conclusions on the optimal design of reduced-windfall options. Indeed, it is unlikely that one size would fit all. The optimal design might well vary from industry to industry and perhaps even from firm to firm. Our main point is that using some form of windfall-reduction is likely to be optimal for at least a significant fraction of, if not all, companies.

b) Other methods of reducing windfalls. Although tying the exercise price of options to market or sector indexes is the best known and

118 There are other possible benefits to indexing that we have not addressed. For example, it has been argued that indexing the exercise price of options could reduce the executive's exposure to market risk. See Holmstrom, 13 Bell J Econ at 328-30 (cited in note 8); Holmstrom, 10 Bell J Econ at 74-75 (cited in note 8). But see Gerald T. Garvey and Todd T. Milbourn, Market-Indexed Executive Compensation: Strictly for the Young at 2, working paper (2001), available online at $<$ http://www.finance.commerce.ubc.ca/research/abstracts/BUCFIN00-6.html> (visited May 5, 2002) (arguing that older, wealthier executives can always offset the market risk generated by non-indexed options by reducing their equity portfolios); Jin, CEO Compensation, Diversification and Incentives at 25 (cited in note 109) (observing that indexing shifts market risk back to shareholders who might also be risk averse, and thus that from a pure risk-sharing perspective the optimal contract might not involve indexing); Core and Guay, When Contracts Require Risk-Averse Executives to Hold Equity at 1-4 (cited in note 109) (observing that to the extent that a firm requires managers to invest in firm shares rather than use the funds to invest in the market, non-indexed options expose the managers to market risk that they would have been exposed to in any event); David M. Schizer, Tax Constraints on Indexed Options, 149 U Pa L Rev 1941, 1942-43 (2001) (arguing that executives would prefer market risk to additional firm-specific risk). In any event, our focus is not on the riskiness of conventional options but rather on the fact that the random noise associated with conventional options has significant positive value. 
perhaps the most effective way of reducing managers' gain from windfalls beyond their control, other approaches could be used.

One other approach that has been used to reduce managers' rewards from windfalls is performance-conditioned vesting of options. Under this approach, managers who do not meet certain performance targets forfeit their options. The exercise price is usually set to the market price on the date of grant. Thus, if the executive is permitted to exercise the options, he can profit to the full extent of the stock price appreciation. However, the options do not vest (become exercisable) unless certain performance targets are met.

These performance targets might involve an index. For example, the executives might be required to generate share price increases that beat the market or a basket of similar stocks. This approach is like an indexed option in that there is no payout unless the share price exceeds a certain benchmark. Thus, to the extent that the increase of a firm's stock price merely reflects market- or sector-wide changes, the managers do not receive a reward. It is unlike an indexed option in that the payout, if made, corresponds to the absolute share price increase rather than the amount by which the stock price exceeds some benchmark.

The performance targets can also use other benchmarks. For example, vesting could be conditional on the firm's earnings per share, net asset value, return on capital, and/or cash generation. Such measures might not screen out sector-wide effects (for example, the effect of an increase in oil prices on an oil drilling firm) but might screen out market-wide effects (such as a decline in interest rates). Another approach is to provide cash or shares to executives who beat the market or the sector (depending on the particular plan) over a three-, four-, or five-year period.

3. The rare use of reduced-windfall options.

Only a small fraction of companies use reduced-windfall options even though options, as we have noted, now represent the largest single component of the average executive's compensation package. ${ }^{10}$ To the best of our knowledge, there is only one publicly traded firm that indexes its options: Level 3 Communications, a computer networking firm, which ties the exercise price of executive options to the S\&P 500

119 Another variation of performance vesting, which is more favorable to executives, enables executives to accelerate the vesting of their options if they meet specified performance targets. Because this form of performance vesting makes the option more valuable to a manager than a conventional option (with the same strike price and initial vesting period), it does not reduce the reward from windfalls.

120 See Murphy, Executive Compensation at 70 (cited in note 2) (finding that only one out of one thousand large public companies examined indexed the exercise price of options to market or peer performance). 
index. Not surprisingly, Level 3 Communications has attracted considerable attention from the financial press and has garnered widespread praise for its shareholder-friendly approach to executive compensation.

There are also a small number of firms - such as Monsanto and Citigroup - that reduce option windfalls to executives by conditioning option-vesting on the firm meeting certain performance targets. For example, Monsanto will not allow the CEO's options to vest unless he generates shareholder returns of at least 10.5 percent per annum over a five-year period. $^{122}$ Like Level 3 Communications, these firms are widely praised by the business press and by prominent market personalities such as Warren Buffett. ${ }^{23}$ However, the use of performanceconditioned vesting is rare. Only 5 percent of the 250 largest publicly traded firms condition option vesting on performance.

Accordingly, the overwhelming majority of executives are rewarded for absolute share price increases, even though such increases might be purely a function of broad market or sector movements. Thus, an executive whose firm's stock price has increased because of favorable sector- or market-wide developments can make a large profit by exercising her options and selling the acquired stock even when she was not in any way responsible for the share price increase. Indeed, during the 1990s stock market boom, an executive might have made a large amount of money even if her firm's performance was worse than that of every other peer firm. Remarking on the situation, Warren Buffett has said, "There is no question in my mind that mediocre CEOs are getting incredibly overpaid. And the way it's being done is through stock options."

121 See Joann S. Lublin, Pay for Outperforming: James Crowe, Chief of Level 3 Communications, Makes the Case for Linking Stock Options to Market-Beating Gains, Wall St J R8 (Apr 6, 2000) (reporting on Level 3 Communication's use of S\&P 500 indexed options and noting that "[t]oday, no other public corporation takes such a daring approach to equity compensation").

122 See Tully, Raising the Bar, Fortune at 272 (cited in note 6).

123 Id.

124 See Alan Levinsohn, A Garden of Stock Options Helps Harvest Talent, 82 Strategic Fin 81, 81 (2001). Another 15 percent use performance-vesting options that accelerate vesting if certain targets are met. Id. Such accelerated-vesting options are more favorable to managers than similar conventional options without an acceleration feature. If the performance target is not met, the payout associated with the acceleratedvesting options is the same as that of a conventional option with some exercise price and maturity. Thus, the accelerated-vesting option permits managers to reap the same windfalls as holders of conventional options. However, they might be preferable to conventional options if the acceleration feature induces the executives to exert more effort or make decisions that are better for shareholders.

125 Tully, Raising the Bar, Fortune at 272 (cited in note 6). 
4. Is there an adequate optimal contracting explanation?

Why then do we not observe more reduced-windfall options? Financial economists have tried to come up with explanations. As we show below, however, none of the suggested explanations can adequately explain the rare use of such options.

a) Design costs. It has been suggested that it might be too costly to design schemes that filter out the industry or market noise that gives rise to windfalls. ${ }^{126}$ However, the economic cost of filtering does not seem to be a plausible explanation for the absence of reduced-windfall options. A wide variety of sector and broader market indices are reported daily in The Wall Street Journal and are available online from numerous sources. Moreover, the SEC's executive compensation disclosure regulations already require public corporations to select and present industry, line-ofbusiness, or peer-group stock price performance data. ${ }^{127}$ Firms are thinking about the relevant indices and tracking these data already. Incorporating this information into their option plans would be trivial.

b) Avoiding distortions in managers'decisions to enter other industries. It has also been suggested that the optimal agency contract might not involve filtering out industry noise. Shareholders, it is postulated, might prefer incentives that prompt executives to adapt to poor industry conditions by shifting company resources into more profitable sectors. ${ }^{128}$ Providing such incentives requires rewarding managers not only for their own efforts in a given sector, but also for sector-driven rises beyond their control.

This sector-shifting explanation is unlikely to explain the lack of reduced-windfall options, however. To begin, it is not clear that investors want established firms to shift between industries. Investors can diversify across industries as they choose. Having decided to invest in an industry and to accept the sector-specific risk, diversified investors might simply want their firms to outperform the others in that sector. Second, and more importantly, even if investors are seeking maximum absolute performance rather than maximum performance within a sector, one could still easily reduce certain windfalls without adversely affecting managers' incentives. In particular, a firm that wished to encourage managers to shift into more profitable sectors and reduce windfalls

126 See Surya N. Janakiraman, Richard A. Lambert, and David F. Larcker, An Empirical Investigation of the Relative Performance Evaluation Hypothesis, 30 J Acct Rsrch 53, 66 (1992).

127 See 17 CFR § 229.402 (2001).

128 See Janakiraman, Lambert, and Larcker, $30 \mathrm{~J}$ Acct Rsrch at 67 (cited in note 126). Compare Ronald A. Dye, Relative Performance Evaluation and Project Selection, 30 J Acct Rsrch 27, 28 (1992) (arguing that managers who are paid based on performance relative to their sector will prefer to operate in industries where their relative talent, not their absolute talent, is greatest). 
could employ a relatively broad index, such as the S\&P 500 (rather than an industry-specific index) to screen out market-wide (rather than sector-wide) rises that are beyond the managers' control. The failure of all but a handful of firms to use any form of reduced-windfall options, then, suggests that sector-shifting considerations cannot explain the absence of these options.

c) Softening industry competition. Strategic considerations underlie one explanation for the near-absence of reduced-windfall options. There is evidence that executive compensation is positively related to the performance of rival firms, particularly in industries that are subject to high levels of product competition, and it has been suggested that implicitly linking pay to rival firm performance in such cases serves shareholders by softening competition and making supra-competitive returns possible.

Once again, however, while fostering collusion among firms in competitive markets might explain the failure to filter out sector-wide price increases, the theory does not explain why these companies fail to filter out broader price increases. In addition, the limited evidence concerning the use of explicit relative performance evaluation cuts against these strategic explanations: In annual incentive plans where we do observe such explicit evaluation, industry peer group comparison is overwhelmingly favored over broad-based comparison. Therefore, the implicit collusion theory does not appear to offer strong support for firms' almost complete failure to use reduced-windfall options.

d) Retaining CEOs during market booms. Himmelberg and Hubbard offer an explanation for firms' failure to filter out broad market effects based on the scarcity of talented managers. ${ }^{132}$ They find evidence that CEO compensation is positively correlated with market returns and that the market effect on compensation is stronger in larger firms. They argue that this evidence can be explained by inelasticity in the supply of individuals qualified to run large firms. ${ }^{133}$ On their theory, the demand for executives rises when the economy is robust and companies need to

\footnotetext{
129 See Rajesh K. Aggarwal and Andrew A. Samwick, Executive Compensation, Relative Performance Evaluation, and Strategic Competition: Theory and Evidence, 54 J Fin 1999, 2000 (1999).

130 See id.

131 See Murphy, Executive Compensation at 74, Table 9 (cited in note 2).

132 See Himmelberg and Hubbard, Incentive Pay and the Market for CEOs at 1-3 (cited in note 9). See also Paul Oyer, Why Do Firms Use Incentives that Have No Incentive Effects? at 1-2, Stanford University Graduate School of Business working paper (2000), available online at <http://facultygsb.stanford.edu/oyer/wp/luck.pdf $>$ (visited Apr 27, 2002) (presenting a model in which it is optimal to pay individuals for group-level, industry-level, or economy-wide performance because agents' opportunities are correlated with aggregate performance and it is costly to adjust terms of employment contracts).

133 See Himmelberg and Hubbard, Incentive Pay and the Market for CEOs at 1-3 (cited in note 9).
} 
pay CEOs more to retain them. Allowing stock option rewards to increase with increasing market levels during boom periods responds to this need. CEO talent is more important and the supply less elastic in the case of large firms, they suggest, and for this reason large firms need to make executive pay even more sensitive to broad stock market levels.

To begin, it is not clear that a CEO is likely to take a new job outside his current industry. If such a move is unlikely, the CEO's compensation need not be tied to broader market movements. Rather, his pay needs to be linked only to the performance of his own industry. The CEO could then be paid with options designed to reduce market-based but not sector-based windfalls. The "market boom" theory therefore cannot explain the use of conventional options in situations where CEOs are unlikely to be offered a job in a different industry.

In addition, the market boom theory appears to assume that the $\mathrm{CEO}$ and the firm cannot renegotiate his salary if he gets a better offer. However, there is no reason to believe that in most cases the CEO and his firm would not be able to adjust his compensation in the face of a higher outside offer. When renegotiation is possible, it would make sense for a firm to pay the CEO with options that screen out sector and broader market rises and then retain the CEO by countering any outside offer with one that is even more attractive. The advantage of this approach compared to the use of windfall-rewarding options is that the firm saves money by not paying the executive extra compensation unless and until he receives an attractive outside offer.

Finally, even if renegotiation were difficult and CEOs were likely to be hired by firms in other sectors, the market boom theory still fails to adequately explain standard practices that tie executive compensation to broad stock price increases. Consider a company that signs a three-year contract with its CEO. The CEO is given options that vest gradually over the three-year period. Suppose that the company seeks to address a scenario in which, after two of the three years, the economy booms, the stock market rises, and the executive is tempted to switch to a higherpaying firm. At this point, increasing the value of unvested options to reflect the hypothesized increased demand for CEOs might assist in retention. Two-thirds of the options would have vested, however, and increasing the value of any of the vested options that are still unexercised would further increase the executive's compensation without increasing the executive's opportunity cost of departing. If a company is concerned about retention in the foregoing scenario, establishing a mechanism through which executives are issued additional reduced-windfall options 
in the event of a market boom would be superior to granting conventional options.

e) Discouraging excessive risk alteration. Saul Levmore has offered a "super-risk alteration" explanation for the lack of indexing (which, we should note, would also apply to other types of reducedwindfall options). According to Levmore, indexed options would encourage managers to differentiate their firms from the index in order to increase the likelihood that their options would be in-the-money. ${ }^{135}$ This in turn could cause managers to forgo the best projects in favor of lower-value projects that have higher volatility (relative to the index).

But even if indexing affects managers' choice of projects, it is not clear that indexing would overall worsen managers' decisionmaking. Indeed, it could have the opposite effect. It is well understood that riskaverse managers tend to prefer low volatility projects, even when they do not maximize the present value of the firm's assets. Options, which increase the reward to managers for choosing projects with more volatile distributions, give managers an incentive to choose riskier projects. Indeed, that is one of the reasons managers are given options in the first instance. However, there is no reason to believe that ordinary options completely overcome the effects of managerial risk aversion. Managers might still avoid some high-value but high-volatility projects. In such a case, if indexing were to affect managers' project choice in the manner suggested by Levmore, it could overall improve the quality of projects chosen.

In addition, even if Levmore is correct that indexing would overall worsen the quality of projects selected by managers, it does not automatically follow that this effect would be sufficiently large to overcome the potential benefits of indexing-namely, the increased incentive to exert effort and boost shareholder value, given whatever project has been selected. Finally, even if the adverse effect suggested by Levmore were sufficiently large to outweigh the benefits of indexed options in most cases, there is no reason to believe that indexed options would create worse overall incentives in the overwhelming majority of publicly

135 Saul Levmore, Puzzling Stock Options and Compensation Norms, 149 U Pa L Rev 1901, 1922-23, 1930 (2001). Options with performance-conditioned vesting could have similar effects.

136 Id at 1923, 1930. Levmore acknowledges that the problem with indexed options he identifies cannot explain the failure to give indexed options to employees who either (1) do not have control over the firm's project choice or (2) are easily monitored. See id at 1931. To explain the failure to give indexed options to these categories of employees, Levmore argues that a norm of "non-conflicting fortunes" prevents firms from distributing options in such a way that some employees' options would be in-the-money and others' would be out-of-the-money. Id at 1931-32. Thus, the need to give some employees (including the CEO) conventional options requires that every other employee get conventional options. See id at 1932-35. 
traded firms. The potentially adverse risk-alteration effects of indexed options are thus unlikely to account for their almost complete absence.

f) Saving taxes. David Schizer has identified a potential tax advantage of conventional options over indexed options that could, it is argued, be a partial explanation for the absence of indexing. ${ }^{137}$ As noted in Part II.B.1, since 1994 the annual pay of a CEO or top officer in excess of $\$ 1$ million has not been deductible by a publicly held corporation unless the excess compensation is performance-based: namely, the compensation is based upon the achievement of performance goals established by ${ }_{138}$ compensation committee composed solely of independent directors. Both conventional and indexed options qualify as performance-based. ${ }^{139}$ However, because a conventional option does not screen out market or industry effects, the option provides some value to managers that is not performance-based. Thus, a conventional option offers non-performance-based pay that is exempt from the $\$ 1$ million deductibility cap. The tax benefit identified by Schizer would be useful to a taxpaying firm that wishes to give a manager non-performance-based pay in excess of $\$ 1$ million and desires to give that pay in the form of a call on the market.

However, indexed options were extremely rare even before this rule took effect in 1994. Moreover, many firms do not pay any taxes because they are not yet profitable, and almost all of these firms do not use indexed options. ${ }^{14}$ Thus, as Schizer acknowledges, this tax advantage cannot entirely explain the almost complete absence of indexed options.

g) Reducing managerial risk-bearing cost. It has been argued that standard indexed options (options whose exercise price is indexed to the sector or market average) would impose too much additional risk of nonpayment on risk-averse executives. Kevin Murphy reports that the probability that a given stock will earn returns in excess of a value-

137 See David M. Schizer, Tax Constraints on Indexed Options, 149 U Pa L Rev 1941, 1942-43 (2001). As the discussion should make clear, one could also argue that the tax advantage of conventional options is a partial explanation for the lack of options with performance-conditioned vesting.

138 See 26 USC § $162 \mathrm{~m}(1994)$.

139 See Schizer, 149 U Pa L Rev at 1942 (cited in note 137).

140 It is not clear that, in an optimal contracting framework, even a tax-paying firm would ever wish to give a manager this type of non-performance-based pay. Schizer suggests that this form of pay might be valuable to risk-averse managers who do not want their pay tied entirely to firm-specific performance. But if managers are risk-averse they would place more value on cash than on a call option with the same expected value. Thus, from an optimal contracting perspective, it would not make sense to give a manager a call on the market with an expected value of $\$ 1$ unless the risk-adjusted value of the call to the CEO, $\$ x<\$ 1$, is greater than the after-tax cost of the call to the firm, $\$(1-t)$. If $\$ x<\$(1-t)$, it would be cheaper for the firm to give the manager $\$ x$ of nondeductible cash than a call option with an expected value of $\$ 1$ that costs the firm $\$(1-t)$. Put differently, conventional options are not a useful form of non-performance-based compensation unless the CEO discounts this risky form of pay by less than the firm's marginal tax rate. 
weighted index is below 50 percent, while a typical ten-year conventional option that is (like most conventional options) granted at-themoney has a probability of expiring in-the-money of over 80 percent. Presumably, risk-averse executives given standard indexed options rather than conventional options would demand indexed options that have a higher expected value than the conventional options they would be replacing. The same claim could be made with respect to options subject to performance-conditioned vesting.

There are at least two problems with this argument. First, and most importantly, a reduced probability of payout is not an inevitable consequence of indexing. To be sure, indexing to sector or market averages would generally reduce the probability of a payout. But as we have emphasized, standard indexing is not the only possible form of indexing. One could instead effect a more moderate form of indexing that would put the CEO in-the-money even if she beats fewer than 50 percent of the other firms. In fact, one could easily design an indexed option that has the same probability of payout as a conventional option.

Suppose, for example, that conventional ten-year options have an 80 percent likelihood of payout, and that one wished to design a tenyear sector-indexed option for ABC's CEO with the same probability of payout. And suppose that there are ten firms in ABC's sector. One could simply tie the exercise price of the CEO's options to the stock price performance of the second worst performing firm in ABC's sector. Thus $A B C$ 's $C E O$ will get a positive payout as long as $A B C$ is one of the eight best performers in the ten-firm sector (and, of course, the better ABC performs, the higher the payout). The advantage of such an indexed option over a conventional option with the same payout probability is that it provides much better incentives than the conventional option by screening out market- and sector-wide effects and thereby tying the CEO's compensation much more closely to the firm-specific value he creates.

Second, even if one wished to use standard indexed options, and moving from conventional to standard indexed options requires increasing the expected value of the CEO's compensation, there are likely to be at least some cases in which shareholders would prefer such a tradeoff. Shareholders would prefer such a tradeoff whenever the extra value generated by improving the CEO's incentives exceeds the amount of additional compensation that must be paid to the CEO to offset the additional risk of nonpayment. It is highly unlikely that in almost every pub-

141 See Kevin J. Murphy, Explaining Executive Compensation: Managerial Power versus the Perceived Cost of Stock Options, 69 U Chi L Rev 847, 863 (2002). 
licly traded firm the CEO is so risk-averse that the additional compensation that must be paid to the CEO in order to compensate him for the extra risk imposed by standard indexed options exceeds the additional value that would be created by improving the CEO's incentives.

h) Managers' ability to undo indexing. It has been argued that indexing might be futile because managers can always make adjustments in their portfolios to offset the effect of indexing. According to this argument, managers' outside investments generally are not restricted. If a manager is given indexed options (which, for example, screen out market effects), she can use personal assets to invest in the market portfolio in such a way that the combination of (i) the indexed options and (ii) her market portfolio investment generates the returns of a conventional option on her firm's stock. If such adjustments can be made, the argument goes, then there is no purpose incurring transaction costs to create indexed options in the first instance.

To be sure, a manager given indexed options can invest her own funds in a portfolio that is designed to combine with her indexed options in a way that yields the returns of a conventional option on her firm's stock. But the fact that the manager can buy such a portfolio with her own money hardly means that it would be optimal for the firm to buy this portfolio for her. Not doing so would save money that the firm could make available to shareholders directly or use to create more powerful incentives for the manager.

The only reason to give the manager conventional options is if it is desirable for shareholders that the manager have such a portfolio. We have seen, however, that this is unlikely to be the case. In short, the ability of the manager to put together such a portfolio does not mean that the firm should use its limited compensation dollars to do that itself.

\section{Accounting considerations.}

A final and very commonly voiced explanation for the lack of indexing deserves special attention because it applies not only to indexing but also to performance-conditioned vesting. Most practitioners and many academics attribute the dearth of indexing at least in part to the unfavorable accounting treatment of these options. Under FASB

\footnotetext{
142 See Li Jin, CEO Compensation, Diversification, and Incentives, working paper (2001), available online at $<$ http://papers.ssrn.com/id=254260 $>$ (visited Apr 27, 2002).

143 In principle, one could also design financial contracts that, in conjunction with options whose vesting is performance-conditioned, would replicate the return of a conventional option.

144 See, for example, Murphy, Executive Compensation at 21 (cited in note 2); Hall and Liebman, Taxation of Executive Compensation at 6 (cited in note 57) (reporting practitioners' assertion that option plans with "bad accounting" are not seriously considered).
} 
rules, a company is not required to take a charge against earnings when it issues an option with a predetermined exercise price and expiration date and that exercise price equals or exceeds the fair market value of

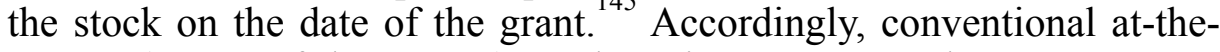
money (or out-of-the-money) stock options never produce a corporate earnings charge. Indexed options, however, lack a fixed exercise price and therefore fall outside of this charge-free zone. Companies issuing indexed options must mark these options against the market on a regular basis and accrue an earnings charge reflecting the appreciation in the value of the option over the indexed exercise price. So, the argument runs, conventional options are preferred over indexed options because the former result in higher reported earnings, which enhance share value. ${ }^{46}$ Options that do not vest unless performance conditions are met are subject to the same unfavorable accounting treatment as indexed options.

a) Some firms already use reduced-windfall options. If accounting considerations were to preclude the use of reduced-windfall options, we would not expect any firms to be observed using them. However, as noted earlier, 5 percent of the largest 250 firms use options that do not vest unless executives meet certain performance targets. These options - like indexed options - must be charged against accounting earnings. This suggests that unfavorable accounting treatment is unlikely to explain other firms' failure to use reduced-windfall options. Furthermore, in at least several cases, institutional investors have put forward shareholder resolutions calling for indexing, which they would not do if indexing were expected to hurt share value.

b) If the stock market is efficient, accounting should be irrelevant. The accounting explanation assumes that the cost of conventional options is hidden from the stock market if it is not charged to earnings. But firms not reporting the actual cost of conventional options as an accounting expense are required to disclose, in the footnotes to their financial statements, pro forma net income and earnings-per-share figures that include an accounting adjustment for these options (based on the grant-date value). ${ }^{147}$ Thus, if market participants read the footnotes they should be able to figure out how the issuance of conventional options affects accounting earnings.

\footnotetext{
145 See APB Opinion No 25. See also Ronald L. Groves, Executive Compensation 9214.04 at 498 (CCH Tax Transactions Library 1992).

146 To the extent that the managers' bonuses are based on reported earnings, higher earnings also increase the bonuses. But presumably if the board were sophisticated enough to use indexed options, it would understand that the bonus formula would need to be adjusted to reflect the accounting effect of these options.

147 See Statement of Financial Accounting Standards No. 12314 (Oct 1995).
} 
To be sure, reduced-windfall options would require marking-tomarket and accruing an earnings charge every quarter in which the options become more in-the-money. Conventional options do not. Thus, the difference between conventional and reduced-windfall options is not only their location on the income statement, but also the frequency with which they appear on the income statement. However, the value of the option at the grant date should equal the expected value of the payoff of the option. Thus, the amounts reported as charges to earnings in the income statement should not, on average, exceed the amounts reported in footnotes.

Given the pro forma disclosure requirement associated with conventional options, one may question whether the "unfavorable" treatment of reduced-windfall options affects the stock price of a company that adopts these options. Are stock prices affected differently if an earnings charge appears in the income statement rather than in the footnotes? If stock prices largely reflect publicly available information in accordance with the semi-strong form of the efficient capital markets hypothesis, ${ }^{18}$ the location of the disclosure does not matter and the unfavorable accounting treatment of reduced-windfall options would not adversely affect stock prices.

c) Even if markets are inefficient, the use of reduced-windfall options might still make shareholders better off. We accept the possibility that markets are not perfectly efficient and that the disclosure mechanism might therefore affect a company's stock price. Even if this is the case, however, it does not follow that the lack of reduced-windfall options reflects optimal contracting. It may be that executives of firms not using reduced-windfall options avoid them because the charges resulting from their use would have a negative impact on the firms' stock prices. If so, avoiding indexing in these cases might be in shareholders' interest. But this would be the case only if, with respect to the firms that do not use reduced-windfall options and that have not been asked by shareholders to institute them, (i) the market is inefficient; (ii) the market is sufficiently inefficient that there will be a substantial short-term decline in the price from moving to indexed or performance-conditioned options (in the long run, presumably, the stock price will reflect the fundamental

148 See Richard A. Brealey and Stewart C. Myers, Principles of Corporate Finance 369 (Irwin McGraw-Hill 6th ed 2000).

149 Responding to the concern that investors may be misled by the company disclosing options expense only by footnote, Microsoft's CFO noted, "[T]he Street figures it out pretty fast." Laura Jereski, Share the Wealth: As Options Proliferate, Investors Question Effect on Bottom Line, Wall St J A1 (Jan 14, 1999). See also Rappaport, New Thinking, Harv Bus Rev at 94 (cited in note 113) (arguing that option disclosure has the same effect on stock price whether the information appears in the income statement or in its footnotes) 
value of the firm); ${ }^{150}$ and (iii) the cost of the short-term decline in share price to shareholders (who might sell in the interim for liquidity reasons) is greater than the benefit of using reduced-windfall options. It is far from clear that all these propositions hold for firms in general and that accounting considerations can thus provide a complete explanation for the almost complete absence of reduced-windfall options.

\section{The managerial power explanation.}

Although optimal contracting considerations cannot easily explain why the overwhelming majority of firms do not use any form of reduced-windfall options, the managerial power approach offers a number of compelling reasons for the almost complete absence of these mechanisms.

Most importantly, for the same reasons that reduced-windfall options would be better for shareholders, these options would be less favorable to managers: reduced-windfall options would provide managers with less money or would require them to cut managerial slack, or both. Thus, as long as managers can get away with the use of conventional options, they will do so.

As we explained above, the expected value of a conventional option is substantially greater than that of a reduced-windfall option. Specifically, the return on the conventional option is equal to the windfallreduced return plus the windfall portion of the return that is screened out by, for example, indexing. Consider, for example, an option indexed to the firm's sector. Since the market return has a substantial expected value for any given period, the value of a conventional option is much greater than that of the indexed option. An executive of a company that performs worse than all of the other firms in its sector might receive no gains from an indexed option, but would receive substantial gains from a non-indexed option in any case in which the firm's stock price increases over time.

The prospect of gains arising from market and sector movements does not have any incentive effect on managers. As we explained earlier, from the shareholders' perspective these gains represent wasted money. By tying the options to market or sector performance, the firm could create the same incentives at a lower price, saving shareholders money. Alternatively, the firm could use the same amount of money it currently spends on conventional options to give managers a larger number of re-

\footnotetext{
150 There is considerable evidence that the market sees through obvious accounting manipulations, which suggests that many in the market would ignore the change in accounting earnings due to a one-time move to reduced-windfall options.
} 
duced-windfall options, which would create more powerful incentives. In either case, shareholders would benefit.

But in either case, managers would be worse off. If the firm provides them with the same amount of incentives at a lower cost to shareholders, the managers will earn less. If, on the other hand, the firm provides them with more incentives at the same cost to shareholders, the managers will not earn less but will need to work harder and smarter for the same compensation. For example, the managers might need to downsize their empires, fire loyal but unproductive subordinates, and take other steps that might be personally unpleasant but are necessary to boost shareholder value. Thus, for the same reasons that reducedwindfall options are better for shareholders, they are worse for managers.

Furthermore, indexing the exercise price (or conditioning vesting on the firm outperforming a certain number of other companies) might be undesirable for many managers because it would shine a spotlight on their performance relative to their peers. Sector indexing, for example, would explicitly reveal the ranking of each manager against other managers in the same industry. This, in turn, would expose 50 percent of all managers as being below average. To the extent that managers do not know where they would rank, the fear of being ranked below average might lead all of the managers in a sector-even those who are fairly confident in their abilities - to oppose indexing.

Note that the fear of being exposed as relatively mediocre is completely distinct from the risk of nonpayment under an indexing regime. Suppose, for example, that managers were guaranteed a minimum payment even if their firm performs worse than all other firms in their sector. These managers would still be embarrassed if the board or the compensation committee were forced to report that the reason the managers earned what they did was that the firm was the worst-performing in its sector. Thus, the fear of embarrassment would arise even if the firm adopted a soft form of indexing that provided a greater likelihood of payout than conventional options.

There is a third possible reason why managers might oppose reduced-windfall options - the desire to keep option compensation more camouflaged. Suppose that, as some have claimed, the market is more likely to notice the cost of managers' options when they appear as charges against earnings rather than in the footnotes of their financial statements. In that case, executives may oppose reduced-windfall options also because they believe the increased salience of the charge to earnings will draw additional negative attention to their option compensation. 
Indeed, this fear of exposure may explain managers' fierce resistance to the FASB's attempt to rationalize options accounting. Financially, there is no plausible justification for the disparate treatment of conventional and indexed or performance-conditioned options. The FASB attempted several years ago to impose a requirement, essentially in line with the current treatment of indexed and performanceconditioned options, that all stock-based compensation be accounted for on a rational and consistent basis. ${ }^{151}$ Encountering heated resistance, the FASB stopped short of requiring firms to adopt its "fair value" method of option accounting. Instead, FASB decided to require companies that fail to adopt the new standards voluntarily and instead continue to employ the traditional accounting methods (almost all firms) to disclose the information in footnotes. ${ }^{53}$ Thus, to the extent the market does not fully notice the cost of options reported in footnotes, conventional options enable managers to better camouflage rent extraction.

Of course, in certain situations one type of reduced-windfall option - indexed options - makes executives better off. In particular, if the index declines from the issue date to the exercise date, the exercise price will fall, increasing the profits from exercise of the option. As explained earlier, the amount by which executives would be made better off in such cases is likely to be less, on average, than the amount by which they would be made worse off when the index increases. However, executives are risk averse, and thus might be willing to make such a tradeoff. One might ask, therefore, why managers do not find this aspect of indexing sufficiently appealing.

The answer, we believe, is quite simple. As will be explained in Part III.C, when the stock price declines, executives might be able to get their options repriced at a lower exercise price. In such a case, they have ex post indexing on the downside. However, when the stock price increases for reasons unrelated to the CEO's performance, the options are not repriced at a higher price and the CEO gets to benefit fully. Thus the CEO is in the position of "heads I win, tails I don't lose." And this is better for the CEO than indexing, where there is a favorable adjustment on the downside but also an unfavorable adjustment on the upside.

We are not claiming that the practice of using conventional rather than reduced-windfall options arose because managers consciously preferred and pushed for the use of such options when they were first introduced on a large scale. It may well be the case that those who initially advocated the use of options - whether they were academics, compensa-

\footnotetext{
151 See Statement of Financial Accounting Standards No. 123 at 23-25 (cited in note 147).

152 See Crystal, In Search of Excess at 234 (cited in note 6).

153 See Statement of Financial Accounting Standards No. 123 at 14 (cited in note 147).
} 
tion consultants, institutional investors, or even the managers themselves - had not thought much about the benefits of designing options in a way that prevents or reduces rewards for general market or sector rises. However, for some years now academics, leading investors, and business commentators have understood the advantages of such option designs, and in a number of firms such designs (for example, vesting conditional on performance) have been implemented. Thus, the puzzle for the optimal contracting view is not why the practice of rewarding managers for general or sector increases arose in the first place. Rather the challenge for this view is to explain why this practice has persisted for so long and why designs aimed at reducing such rewards have been introduced so sparingly.

7. Is non-option compensation adjusted to reduce windfalls?

It is difficult to reconcile firms' failure to adopt reduced-windfall options with optimal contracting. Before moving on, however, we should consider whether managers' non-option compensation is adjusted to offset any windfall managers receive through the option component of their compensation so as to better tie total compensation to the value created by the managers' own efforts. That is, companies can take the managers' performance and the managers' option profits into account ex post in adjusting bonuses and future salary, and in deciding whether to retain an executive. For example, the board could reduce the cash compensation of a relatively poorly performing manager who has profited heavily from his options because of sector-wide increases in demand for the industry's product. Conversely, the board could increase the cash salary of a manager who has added value for shareholders but who has not been able to profit from his options because of a stock price decline due to bad industry conditions.

If there is such an adjustment, one would expect cash compensation to be negatively related to industry and market performance. There is some evidence suggesting that changes in cash salary and bonus are

\footnotetext{
154 One might be inclined to think that the practice of using conventional options persists not because of managerial power but simply because of inertia. Indeed, we acknowledged earlier in our discussion of norms that the desire of boards to conform to "the norm" (and avoid the possible risks associated with change) is likely to introduce "stickiness" into executive compensation and slow movement from one equilibrium to another. However, it is unlikely that such inertia can explain the almost universal use of conventional options. First, stickiness has not stopped compensation consultants from rapidly introducing and "selling" to clients new option features that make managers better off-such as reloading and accelerated vesting. Second, a number of the largest and most prestigious firms in the U.S. have already adopted windfallreducing features such as performance-conditioned option vesting. Thus, boards of other firms that are interested in linking compensation more closely to the managers' contribution to shareholder value can, if they wish, easily follow the model created by these early-adopting firms.
} 
negatively linked to industry and market performance. Gibbons and Murphy found that the size of CEO pay raises is negatively correlated with industry and broader market performance. ${ }^{155}$ However, there is apparently no evidence that the absolute amount of cash compensation (rather than changes in cash compensation) decreases with sector or market increases.

Indeed, there is evidence that CEO cash compensation increases with market returns. ${ }^{156}$ There is also evidence - presented in two studies - that managers' cash compensation also increases in response to sector-wide and firm-specific windfalls. The first study, by Blanchard, Lopez-de-Silanes, and Shleifer, ${ }^{157}$ examines what eleven firms did with windfalls they received in connection with won or settled lawsuits, most of which had nothing to do with the current business activities of the firms and thus were unlikely to reflect the efforts of current executives. Most of the cash was retained by the firm. Those firms distributing cash did so either to give a significant dividend to a large controlling shareholder or to repurchase the shares of large outside shareholders that could pose a threat to managers. The study found that 16 percent of the net award was given to the top three executives over three years following the award, boosting median cash compensation to these executives by 84 percent. Some firms also gave more stock and option grants to managers.

The second study, by Bertrand and Mullainathan, ${ }^{158}$ finds that managers are rewarded for sector-related luck. The authors examine the compensation of managers when, because of changes beyond their control, their sector does exceptionally well. The authors study three such situations: (1) when oil price increases boost the performance of the oil industry; (2) when a change in exchange rates benefits import-affected industries; and (3) when, for whatever reason, all other firms in the industry perform well. The authors find that in all of these situations managers are paid the same for a "lucky" dollar as for a "general" dollar.

155 See Robert Gibbons and Kevin J. Murphy, Relative Performance Evaluation for Chief Executive Officers, 43 Indus Labor Rel Rev 30, 36 (1990) (examining 1974-1986 data). A study by Murphy looking at later data determined that the size of increases in cash compensation was negatively related only to broader market performance. See Murphy, Executive Compensation at 2535 (cited in note 2).

156 See Himmelberg and Hubbard, Incentive Pay and the Market for CEOs at 17, 24 (cited in note 9).

157 See Olivier Jean Blanchard, Florencio Lopez-de-Silanes, and Andrei Shleifer, What Do Firms Do with Cash Windfalls?, 36 J Fin Econ 337, 358-59 (1994).

158 See Marianne Bertrand and Sendhil Mullainathan, Do CEO's Set Their Own Pay? The Ones without Principals Do at 37, NBER Working Paper No 7604 (2000), available online at $<$ http://papers.nber.org/papers/w7604.pdf $>$ (visited Apr 27, 2002). We discuss this study further in Part III.G. 
These findings are clearly more consistent $t_{59}$ with the managerial

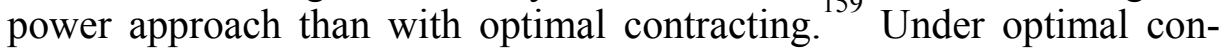
tracting, there is no need to compensate or penalize managers for changes that are beyond their control. Indeed, making compensation depend on such changes is considered undesirable because it adds riskiness to the compensation package and thereby reduces the value of the package to managers. Under the managerial power approach, however, managers are expected to take as much as their power allows, consistent with not triggering too much outrage. Because the windfall increases earnings and makes shareholders as a group better off, managers can increase their compensation at a lower outrage cost. Thus when the firm gains a windfall, managers can be expected to boost their pay.

\section{B. Near-Uniform Use of At-the-Money Options}

An analysis of options granted to the CEOs of one thousand large companies in 1992 determined that 95 percent of the options were granted at-the-money, that is, with an exercise price equal to the company's stock price on the date of the grant. ${ }^{10}$ No one has provided a convincing explanation for this phenomenon, which Hall and Murphy call "striking."

\section{The puzzle of one-size-fits-all.}

There is a debate in the literature as to the optimal exercise price for executive stock options, and researchers have identified various factors that might be relevant for this question. ${ }^{162}$ It is highly unlikely, however,

\footnotetext{
159 The authors of these studies did in fact interpret their results as evidence of "skimming."

160 See Murphy, Executive Compensation at 70, Table 5 (cited in note 2).

161 Brian J. Hall and Kevin J. Murphy, Stock Options for Undiversified Executives at 19, NBER Working Paper No 8052 (2001), available online at <http://papers.nber.org/papers/ w8052.pdf $>$ (visited Apr 27, 2002).

162 Options ordinarily encourage executives to take on additional risk. See, for example, Kevin J. Murphy, Performance Standards in Incentive Contracts, 30 J Acct Econ 245, 273 (2001). Because most managers are underdiversified and risk averse, it generally is assumed that encouraging executives to take on additional risk is positive for shareholders. See DeFusco, Johnson, and Zorn, 45 J Fin at 617 (cited in note 111) But certain option designs might cause executives to take on too much or too little risk. While it is possible to show, under certain assumptions about managerial risk aversion, managers' reservation utility, and project choices, that at-the-money options are optimal, see Nohel and Todd, Optimal Compensation at 4 (cited in note 109), under other assumptions one can show that they are not. See Nohel and Todd, Executive Compensation, Managerial Risk Aversion, and the Choice of Risky Projects at 4 (cited in note 109) (finding that outof-the-money options may dominate both in- and at-the-money options). See also Nohel and Todd, Executive Compensation, Reputation, and Risk-Taking Incentives at 4 (cited in note 109) (showing that in-, at-, or outof-the-money options can align incentives depending on the circumstances); Tom Nohel and Steven Todd, Stock Options and Managerial Incentives to Invest, working paper (2001), available online at $<\mathrm{http}: / /$ www.sba.luc.edu/research/

wpapers/011109.pdf $>$ (visited Apr 27, 2002) (describing circumstances in which out-of-the-money options
} 
that a single design would be optimal for nearly all companies and all executives. Option values and the incentives they create depend on a stock's volatility, the grantee's stock holdings, and the grantee's general level of risk aversion. Moreover, the shape of the desired incentive will depend on a firm's growth opportunities, debt load, and other factors. ${ }^{14}$ These variables will differ from firm to firm, and even among executives within the same firm. Thus, there is no reason for the optimal exercise price to be the same for almost all companies.

There is, however, a possible tax explanation for the almost complete absence of in-the-money options. In particular, in-the-money options are not considered "performance-based compensation" under Section $162(\mathrm{~m})$ of the Internal Revenue Code and are therefore not deductible if an executive's total non-performance-based compensation exceeds \$1 million per year. In addition, options that are granted in-the-money must be taken into earnings, whereas at-the-money and out-of-themoney options need not. Thus, although we are somewhat skeptical of accounting explanations for firm behavior, one might argue that accounting considerations can also explain the absence of in-the-money options.

However, neither the tax nor the accounting explanation can explain the near complete absence of out-of-the-money options. The only possible optimal contracting explanation for this phenomenon is that

best align managerial and shareholder interests); Brian J. Hall, A Better Way to Pay CEOs?, in Jennifer Carpenter and David Yermack, eds, Executive Compensation and Shareholder Value: Theory and Evidence 35, 42 (Kluwer Academic 1999) (arguing that some firms could improve their executive compensation practices by adopting out-of-the-money and indexed options, which provide greater sensitivity to performance than atthe-money options); Johnson and Tian, 57 J Fin Econ at 25-26 (cited in note 116) (arguing that out-of-themoney options create more powerful incentives than at-the-money options of equal value); Richard A. Lambert, David F. Larcker, and Robert E. Verrecchia, Portfolio Considerations in Valuing Executive Compensation, 29 J Acct Rsrch 129, 144 (1991) (arguing that options that are very likely to wind up in-the-money undesirably reduce managers' willingness to take risks).

163 See Nohel and Todd, Executive Compensation, Managerial Risk Aversion, and the Choice of Risky Projects at 7 (cited in note 109).

164 See Chongwoo Choe, Executive Stock Options and Investment Choice at 3, La Trobe University School of Business working paper (1999), available online at $<$ http://www.latrobe.edu.au/business/dps/pdfs/dps99/A99.11.pdf > (visited Apr 27, 2002) (arguing that the exercise price of managerial stock options should be adjusted when the firm has debt in its capital structure). Compare Harley E. Ryan Jr. and Roy A. Wiggins III, The Influence of Firm- and Manager-Specific Characteristics on the Structure of Executive Compensation, 7 J Corp Fin 101, 101-05 (2001) (finding that CEO compensation is affected by firm-specific factors such as research and development and capital expenditure intensities and by manager-specific factors such as the CEO's age).

165 See Tian, Optimal Contracting, Incentive Effects and the Valuation of Executive Stock Options at 40 (cited in note 109) (arguing that the optimal exercise price depends in part on the level of risk aversion and could be in-, at-, or out-of-the-money depending on the executive and concluding that the uniform practice of granting at-the-money options is not supported by principal-agent theory). 
out-of-the-money options are almost never optimal. ${ }^{166}$ However, as Brian Hall has argued, out-of-the-money options offer much higher payfor-performance sensitivity per dollar of expected value than conventional options. And there is empirical evidence suggesting that giving managers out-of-the-money options rather than at-the-money options would, on average, boost firm value. ${ }^{167}$ Thus, it is extremely unlikely that out-of-the-money options are almost never optimal. According to Hall, the "almost complete absence of premium or indexed options seems puzzling given their striking advantages in terms of pay to performance."

While many have noticed that there is near-uniformity among the exercise price of options, little attention has been given to the fact that there are actually two dimensions along which this uniformity occurs: (1) any given firm will use the same exercise price for options regardless of the vesting period of the option-for example, an option that vests in a year has the same exercise price as an option that vests in five years; and (2) almost all firms use the same formula for determining this exercise price, namely, the current market price.

As we saw earlier, the literature has focused on the second pattern. But it has not fully considered the first - that exercise prices are uniform across vesting periods. Note that because prices on average go up, an option that is issued at the current market price is likely to be in-themoney in the future. The effect of such an option on effort then would be equivalent to the effect on effort today of an option that is currently in-the-money. As Warren Buffett has observed, getting rich with at-themoney options vesting over a ten-year period does not require much effort. If the CEO buys government bonds with the firm's earnings instead of paying them out in dividends, the share price is likely to rise over

166 In recent work, Hall and Murphy use numerical simulations in an attempt to derive optimal exercise prices under various assumptions about the shape of managerial utility functions, managerial wealth, stock market returns, and the volatility of the firm's stock. See Brian J. Hall and Kevin J. Murphy, Optimal Exercise Prices for Executive Stock Options, 90 Am Econ Assoc Proceedings 209, 213 (2000). Under a range of parameters, they show that the exercise price that maximizes pay-for-performance sensitivity is usually in a range that includes the current market price. Id. See also Hall and Murphy, Stock Options for Undiversified Executives at 20-22 (cited in note 161) ("[S]etting exercise prices at (or near) the grant-date market price maximizes pay/performance incentives for risk-averse, undiversified executives."). However, their analysis cannot explain why, as they report, 94 percent of option grants are at-the-money. First, there is no evidence that the utility functions they use-which are designed to make their calculations tractable - correspond to those of actual managers. Second, the analysis does not take into account the incentive effects of the options on managerial behavior and the stock price. Third, even if their parameters corresponded to the situations of actual CEOs and incentive effects could be ignored, their parameters generate a range of optimal exercise prices, some of which (under certain conditions) are out-of-the-money. Yet, almost all option grants are atthe-money.

167 See Habib and Ljungqvist, Firm Value and Managerial Incentives at 17 (cited in note 110).

168 Hall, A Better Way to Pay CEOs? at 43 (cited in note 162). 
time. As Buffett puts it, "these [at-the-money] plans are really a royalty on the passage of time."

We certainly do not attempt to analyze here what would be the optimal exercise price of options that are going to vest a number of years from now. This might depend on the time value of money and the rate of inflation. An option exercisable at the current market price that vests in five years will have in real terms an exercise price much lower than the current market price. The important point is that there is little reason to think that the optimal exercise price would not only be uniform across sectors, companies, and executives but also be uniform across vesting periods.

2. The managerial power explanation.

Under optimal contracting, the exercise price of options should be set to maximize shareholder value and, since there is reason to believe that the value-maximizing exercise price might differ across vesting periods and across firms, the uniformity along both dimensions poses a puzzle. Under the managerial power approach, however, the nearly uniform use of at-the-money executive stock option plans can be easily explained. Under that approach, managers are not seeking exercise prices that are value-maximizing for shareholders. Rather, managers are interested in exercise prices that are value-maximizing for managersnamely, the lowest possible exercise price consistent with other constraints.

At-the-money options might well provide the best combination of high rents and low outrage. Holding the number of options granted constant, executives prefer the lowest possible exercise price. Each dollar of strike price reduction is a dollar gained once the option is in-the-money. Thus, executives prefer an option that bears the lowest possible strike price without causing too much outrage.

Granting in-the-money options might appear to provide a gift to the executives - "incentive" compensation that requires no improvement in performance - and thus might spark some outrage. In addition, as we explained above, a grant of in-the-money options would force the firm to reduce accounting earnings by the amount by which the options are in-the-money. ${ }^{170}$ To the extent that firms refuse to issue options that reduce accounting earnings, this requirement sets a floor for the exercise price at the current market price. We are a bit skeptical about the force

\footnotetext{
169 Tully, Raising the Bar, Fortune at 272 (cited in note 6).

170 In addition, as noted earlier, in-the-money options do not qualify as performance-based compensation under IRC $\S 162(\mathrm{~m})$
} 
of the accounting explanation for the lack of indexing, as we noted earlier. Rather, we think that firms might be using accounting effects as an excuse for not using reduced-windfall options. If this is in fact the case, firms could not use in-the-money options with their adverse accounting effects, because this would remove the excuse that adverse accounting effects prevent them from using reduced-windfall options.

The above discussion explains why plan designers might be reluctant to use in-the-money options. This leaves, however, a range of possible exercise prices at or above the grant-date market price. Within this range, the lowest possible exercise price is the grant-date market price. And this exercise price can plausibly be justified because managers profit if and only if the stock price increases above its current level. And there may well be some situations in which at-the-money options are indeed optimal. Thus, in any given firm, at-the-money options are unlikely to generate any outrage. The empirical observation that exercise prices are almost uniformly set to the company's stock price on the date of the grant, regardless of the vesting period, the type of company, and the stage of the executive's career-all factors relevant for economic optimization - is thus consistent with rent extraction constrained by the possibility of outrage.

\section{Resetting of Option Exercise Prices}

In many cases, corporations have lowered the strike prices of options when their stock prices fell below the original exercise prices, but firms have rarely raised strike prices in a rising market. This one-sided practice of resetting is yet another feature of option practice that is puzzling from an optimal contracting perspective, but consistent with the managerial power approach.

Although not universal, the practice of resetting was fairly common in the 1990s, even though the market as a whole was performing well. Examining the S\&P ExecuComp database for 1992-1995, Brenner, Sundaram, and Yermack found that on average 1.3 percent of executives had options reset each year. ${ }^{171}$ Of 806 individual option resets, they found that the strike price was increased in only two cases, and they calculated an average reduction in exercise price of 39 percent. $^{172}$ It is

171 See Menachem Brenner, Rangarajan K. Sundaram, and David Yermack, Altering the Terms of Executive Stock Options, 57 J Fin Econ 103, 110 (2000). See also Kathy B. Ruxton, Executive Pay, 1998: Chief Executive Officer Compensation at S\&P Super 1,500 Companies as Reported in 19982 (Investor Responsibility Research Center 1999) (finding that 3 percent of 1189 firms surveyed by the IRRC repriced options in 1998).

172 See Brenner, Sundaram, and Yermack, 57 J Fin Econ at 112 (cited in note 171). 
worth noting that the S\&P 500 Index rose by about 50 percent during the period studied by the authors, with no significant downturns. The frequency of resetting is likely to be much higher in falling markets.

1. The resetting puzzle.

Ex post adjustments to compensation contracts have troubling implications that make them difficult to explain within an optimal contracting framework. Clearly, the expectation that firms will adjust ex post for adverse stock price movements undermines ex ante incentives. Thus, the practice of ex post resetting undermines the goal that underlies the very use of stock option plans. Indeed, if executives anticipate that the exercise price will be reset if the stock price falls, they might have an incentive to take steps to reduce the share price in the short run in order to lower the exercise price.

Companies claim that these adjustments are necessary to retain and motivate executives when prices fall to levels that make existing options far out-of-the-money. Although ex post resetting undermines ex ante incentives to some extent, so the argument goes, companies might determine that on balance these ex post retention and incentive benefits outweigh the ex ante costs.

However, when stock options have a long maturity and the stock is highly volatile, even a steep fall in the share price might not substantially change the value of, and the incentives provided by, the options. Thus, the retention and incentive justifications for repricing options do not always apply.

Even when a fall in stock market price does eliminate incentives, optimal contracting suggests that companies should adjust option terms to provide better incentives going forward, not merely to transfer value to recipients. If exercise prices are reset, for example, vesting periods should be reset as though the options were granted on the date of the repricing. There is no incentive or retention reason to give executives any

173 The FASB has issued new guidelines that impose unfavorable accounting requirements on companies that reset the exercise price of outstanding options. One might therefore believe that even if stock prices fall, firms will be more reluctant to reprice options. However, no such requirements are imposed when the firm simply gives executives an equivalent number of new options at a lower strike price without canceling the old options, which is a common approach to "resetting" exercise prices. In addition, there are no unfavorable accounting consequences if the firm cancels the old options and issues the new options with a strike price set to the market price on a date that is at least six months and one day after the cancellation.

174 See Viral V. Acharya, Kose John, and Rangarajan K. Sundaram, On the Optimality of Resetting Executive Stock Options, 57 J Fin Econ 65, 67 (2000).

175 See Li Jin and Lisa Meulbroek, Do Underwater Executive Stock Options Still Align Incentives?: The Effect of Stock Price Movements on Managerial Incentive-Alignment at 39-40, Harvard Business School working paper (2001), available online at <http://www.people.hbs.edu/ lmeulbroek/02-002.pdf> (visited Apr 27, 2002). 
benefit from fully or partially vested options that have lost their value. Any such benefit would therefore constitute a windfall.

It has been argued that, even if resetting is undesirable following a company-specific price decline, it might be appropriate after a general market downturn, because such an event is outside of the executives' control and executives will demand a large risk premium if there is no adjustment for general market corrections. ${ }^{976}$ But repricing conventional options in the wake of a market downturn appears to be a second-best result compared with indexing the options against market movements in the first place. Ex post adjustment of the terms of indexed options that automatically correct for sector-wide (or at least market-wide) shocks will generally be less necessary, and will certainly be more difficult to justify.

Consider two regimes. In the first, executives receive conventional options and fall back on resetting when the market moves against them. This arrangement allows the executives to reap the gains that come with a market-wide rally, even if the rally simply offsets an earlier market slide. So resetting provides much more than downward price protection-resetting lets executives "buy" on major market dips. Moreover, because the determinants of share prices are complex, executives can justify resetting when only a fraction of the decline in their firm's share price is actually attributable to a market correction.

In the second regime, executives hold standard indexed options, whose exercise price is tied to the sector or market average. The executives are insulated from sector or broad market swings. Resetting becomes difficult, if not impossible, to justify, and market slides do not become opportunities for profit taking on the rebound. Thus, even if the executives receive more indexed options to reflect their reduced expected value, as they should, the loss of the resetting advantage leaves them worse off overall.

Optimal contracting explanations for resetting are further undermined by empirical analyses concerning the use of this device. Brenner, Sundaram, and Yermack find that resetting does not occur as a result of industry-wide shocks, as one would expect if the process were used to avoid penalizing executives for larger trends beyond their control. Rather, resetting is associated with poor firm-specific stock price performance, which might reward the management of poorly performing (1994).

176 See P. Jane Saly, Repricing Executive Stock Options in a Down Market, 16 J Acct Econ 325, 326

177 See Brenner, Sundaram, and Yermack, 57 J Fin Econ at 121 (cited in note 171). 
firms. ${ }^{178}$ Similarly, Chance, Kumar, and Todd find that repricing decisions are not driven by market or industry factors.

2. The managerial power explanation.

From the managerial power perspective, however, the resetting arrangement makes sense. Executives' enjoyment of large option gains when market prices increase across the board can easily be justified to observers in this fashion: There was a contract; it provided incentives; all parties to the contract - shareholders and executives - enjoyed large gains; the firm sticks by its contracts. When the stock price drops, resetting can be justified based on the need to retain and motivate executives as the firm moves forward. If the company is still nervous about public reaction, it can reduce the exercise price somewhat, but leave it above market to show investors that the executives are not getting a free ride.

The practice of resetting must also be considered in light of the failure of companies to index options. As noted above, the combination of effects seems to enhance executive rent extraction. Executives appear to be much better off with conventional options that may be reset than they would be with indexed options. Finally, empirical data also support the managerial power explanation. For example, Chance, Kumar, and Todd find that repricing is more likely among smaller firms with boards that are dominated by insiders and otherwise suffer from greater agency problems. ${ }^{181}$ And Callaghan, Saly, and Subramaniam report that executives release bad news shortly before the date on which the options are repriced and delay the release of good news until after that date in order to reduce the exercise price of the repriced options.

\footnotetext{
178 See id at 120.

179 See Don M. Chance, Raman Kumar, and Rebecca B. Todd, The Repricing of Executive Stock Options, 57 J Fin Econ 129, 131 (2000) (reporting that "poor performance prior to repricing is not driven by market or industry factors"). See also N.K. Chidambaran and Nagpurnanand R. Prabhala, Executive Stock Option Repricing, Internal Governance Mechanisms, and Management Turnover, J Fin Econ (forthcoming 2002) (reporting that repricing firms are likely to have enjoyed rapid, above-industry growth rates and profitability two years before repricing, and a drop to below-industry growth rates and profitability the year of repricing); Mary Ellen Carter and Luann J. Lynch, An Examination of Executive Stock Option Repricing, 61 J Fin Econ 207, 209 (2001) (reporting that repricings follow firm-specific price declines).

180 See Brenner, Sundaram, and Yermack, 57 J Fin Econ at 112 (cited in note 171) (reporting that the strike price was reduced but left above market in about 20 percent of the resetting cases examined).

181 See Chance, Kumar, and Todd, 57 J Fin Econ at 148, 153 (cited in note 179).

182 See Sandra Renfro Callaghan, P. Jane Saly, and Chandra Subramaniam, The Timing of Option Repricing at 3, working paper (2000) (on file with author). See also Yermack, 52 J Fin at 462-64 (cited in note 19) (reporting that managers manipulate news around option grants in order to lower the exercise price).
} 


\section{Executives' Broad Freedom to Unwind Incentives}

Companies claim that they use equity-based compensation as ${ }_{183}$ means of aligning incentives and increasing executive shareholding. But firms take surprisingly few steps to prevent or regulate the unwinding of the incentives provided by the grant of options and restricted stock. ${ }^{184}$ Executives generally are left free to hedge away equity exposure before these instruments vest, and typically are permitted to choose the amount and timing of unwinding once vesting has occurred. The permissive attitude of firms toward managers determining the extent and the timing of incentive-unwinding presents an additional puzzle for the optimal contracting approach.

1. Freedom to determine the amount of unwinding.

Options and restricted shares are awarded in order to provide executives with stronger incentives to generate shareholder value. Because executives are risk-averse, they would prefer to receive the expected value of these incentive instruments in cash. Indeed, they might prefer to receive an amount in cash that is significantly less than the expected value of the incentives. Thus, once the options and restricted shares have vested, executives might wish to convert them into cash. But such an unwinding would eliminate the incentive benefits that come from the executive holding these instruments. As a result, an optimal contract would be expected to restrict executives' freedom to unwind vested options and stock in a way that balances risk-averse executives' desire to cash out these equity-based instruments against the need to provide them with the proper amount of incentives.

It should be noted that the rationale for restricting executives' freedom to unwind vested incentives is not necessarily the same as the rationale for vesting periods. The purpose of a vesting period is to prevent an executive who has just been given options from immediately resigning and walking away with the options (or underlying shares) without having contributed any value to the firm. Once the options have vested,

\footnotetext{
183 See Eli Ofek and David Yermack, Taking Stock: Equity-Based Compensation and the Evolution of Managerial Ownership, 55 J Fin 1367, 1367 (2000).

184 It is not unusual for a firm to use "trading windows" and "blackout periods" to restrict the times during the year that a manager can trade in the shares in order to reduce the possibility that it will be held liable for an insider trading violation. J. Carr Bettis, Jeffrey L. Coles, and Michael L. Lemmon, Corporate Policies Restricting Trading by Insiders, 57 J Fin Econ 191, 192 (2000). For example, many firms permit managers to trade only during the two- or three-week period after quarterly earnings have been released. Id. Such restrictions might sometimes impose liquidity costs on a manager by forcing the manager to delay a planned trade for several months. However, these restrictions do not limit the number of shares that can be sold or the type of transaction that can be entered into when trading is permitted. Thus, these trading restrictions cannot prevent managers from selling or hedging their equity positions.
} 
they are considered to have been earned by the executive and can no longer be taken away. But the fact that the options belong to the executive once they have vested does not necessarily imply that the executive should be permitted to exercise the options and sell the shares acquired thereby immediately upon the options' vesting.

It is possible that the optimal design of option compensation in certain cases would be to prohibit the unwinding of the option for a specified period after the options have vested. For example, it might be desirable to give to a particular executive options that vest in three years but cannot be cashed out during the two-year period beginning with the vesting date. If the executive continues to work for the company during those two years, the options (or, if he has exercised the options, the underlying shares) would provide desirable incentives during that period.

Compare this restricted-unwinding arrangement to the situation in which such options can be exercised immediately on the vesting date, and the executive in fact exercises the options and sells the underlying shares at that time. In this situation, shareholders must either (a) provide the executive with new options to maintain the same amount of incentives, which costs the shareholders more money than under the restricted-unwinding arrangement; or (b) indirectly bear the costs associated with the executive having weaker incentives during the two years following the vesting date than under the restricted-unwinding arrangement.

Furthermore, the restricted-unwinding arrangement is also likely to have an advantage over an unrestricted unwinding arrangement even when the executive does not expect to remain for two years after the vesting date. Even if the executive expects to leave on or shortly after the vesting date, the restricted-unwinding arrangement is likely to provide better incentives to maximize long-term shareholder value than one in which the executive can cash out the options on the vesting date.

To be sure, restrictions on executives' ability to cash out vested incentive instruments would impose some liquidity and diversification costs on executives. These costs must be balanced against the incentive benefits of restricting the unwinding of these instruments. Thus, we are not claiming that in all cases such restrictions would be desirable. Moreover, in those cases where such restrictions on unwinding vested options and stock are desirable, we are not claiming that there is a single optimal length for the restriction period. This is likely to vary from case to case, and would depend, among other things, on the expected length of the executive's tenure at the firm and the executive's diversification and consumption needs. 
What is clear, however, is that there is no reason to assume that the optimal contract would always give the executive the ability to unwind options and restricted stock as soon as they vest. Nevertheless, we observe virtually no attempts by firms to prevent executives from unwinding options and restricted shares immediately after they have vested.

Not surprisingly, executives exercise many of their options well before expiration. A recent study examining ten-year options granted to the executives of forty large companies determined that the options were exercised after an average of 5.8 years. ${ }^{186}$ Moreover, despite the pressure that boards supposedly put on executives to increase their shareholdings, executives sell all or almost all of the shares that are acquired through option exercise, far in excess of the level of sales required to satisfy the taxes due. ${ }^{187}$ Shares that are not sold after option exercise are often hedged in transactions that do not generate taxable income and which are not reported to the SEC. ${ }^{188}$ For example, executives often utilize collars and equity swaps to lock in gains on their shareholdings following a stock price increase, which, of course reduces their incentive to boost the price further.

A similarly puzzling practice is the lack of restrictions on the use of financial instruments to eliminate or weaken the incentive effects of unvested options and restricted shares. Executives generally are not barred from hedging away their equity exposure before these instruments vest. At the moment, several serendipitous features of the federal income tax code reduce the attractiveness of hedging unvested options and (to a lesser extent) restricted stock through the derivatives market. ${ }^{90}$ But

185 See David M. Schizer, Executives and Hedging: The Fragile Legal Foundation of Incentive Compatibility, 100 Colum L Rev 440, 468-72 (2000).

186 See Jennifer N. Carpenter, The Exercise and Valuation of Executive Stock Options, 48 J Fin Econ 127,139 (1998). Because executives are taxed when they exercise most options, the deferral of taxes provides executives with some incentive to delay exercise. See Schizer, 100 Colum L Rev at 468-72 (cited in note 185). Thus, many options are not exercised immediately upon vesting. In a recent survey, the IRRC reported that in 1998 the median S\&P 500 CEO held unexercised in-the-money options worth \$10.9 million and that two-thirds of these options were vested. In 1997, the median CEO had held unexercised options worth \$5.6 million. See Ruxton, Executive Pay, 1998 at 16 (cited in note 171).

187 See Ofek and Yermack, 55 J Fin at 1376-77 (cited in note 183) (finding that "when executives exercise options to acquire stock, nearly all of the shares are sold").

188 See Ellen E. Schultz and Theo Francis, Fair Shares?: Why Company Stock Is a Burden for Many and Less So for a Few, Wall St J A1 (Nov 27, 2001).

189 See J. Carr Bettis, John M. Bizjak, and Michael L. Lemmon, Insider Trading in Derivative Securities: An Empirical Examination of the Use of Zero-Cost Collars and Equity Swaps by Corporate Insiders at 2-3, working paper (1999), available online at <http://papers.ssrn.com/ id=167189> (visited Apr 27, 2002). See also Paul U Ali and Geof Stapledon, Having Your Options and Eating Them Too: Fences, Zero-Cost Collars and Executive Share Options, 18 Co \& Sec L J 277, 277-78 (2000) (describing the use of hedging devices by managers as an "alarming development" that subverts the economic purpose of stock options).

190 See Schizer, 100 Colum L Rev at 442-43 (cited in note 185). 
even modest changes in tax rules could eliminate this disincentive. Thus, there is little reason not to include contractual prohibitions on such unwinding.

Finally, when managers are granted options to align their interests with those of shareholders, it would seem optimal-at least sometimes - for the firms granting those options to require that managers not offset the desirable effect created by these incentives by selling shares they already hold. Yet, such restrictions are generally not used. As a result, executives often sell stock they already hold when options (or restricted shares) are granted.

We want to stress that we are sympathetic to the possibility that in many cases the consumption and diversification needs of managers would require permitting some unwinding of positions before the managers leave the firm. Thus, in certain cases an optimal contract might permit a specified amount of unwinding after option vesting as well as when new options are granted. It might be desirable to write into compensation contracts provisions that authorize the compensation committee to expand the scope of unwinding in case of unanticipated increases in liquidity needs. All that said, however, it would be difficult to explain under the optimal contracting approach the almost universal absence of restrictions on the unwinding of vested options and shares, on the hedging of unvested options and restricted shares, and on the sale of existing shares when new options are granted.

Once again, we believe that the absence of such restrictions can be explained under the managerial power approach to executive compensation. Broad freedom to unwind incentives benefits managers in a way that is not particularly conspicuous. Because plan designers are seeking to benefit managers, even at the expense of public shareholders, the designers are not particularly concerned by the fact that the broad freedom to unwind incentives dilutes the strength of these incentives. Indeed, managers' freedom to unwind incentives and their practice of doing so conveniently serves as a justification for providing the managers with new options and restricted stock to restore incentives. The puzzling absence of any contractual restrictions, even on the hedging of unvested shares and restricted stock, can thus be better understood under the managerial power approach than under the optimal contracting approach.

191 See Ofek and Yermack, 55 J Fin at 1376 (cited in note 183) (finding that managers who already owned shares in excess of the number of options (or restricted shares) granted sold approximately 680 shares for every one thousand options granted and 940 shares for every one thousand restricted shares granted). 


\section{Freedom to determine the time of unwinding.}

The previous discussion makes clear that managers are essentially free to choose the extent to which they unwind their incentives. We now focus on another important freedom managers enjoy with respect to the incentive features of their compensation contracts: that managers are permitted to choose the timing of the unwinding of their incentives.

Consider a situation in which-under an optimal contract-it would be desirable to allow an executive to sell a certain number of shares in a given year, even though the executive is expected to continue to serve the firm for many more years. Suppose, for example, that the executive has liquidity or diversification needs that can be met only by these sales, and that the cost to him from being forced to hold onto these shares exceeds the marginal incentive benefit these shares provide.

The fact that it is desirable for the executive to sell a certain number of shares per year does not imply that the executive should choose the exact timing of the sales. After all, most of these liquidity and diversification needs are unlikely to arise unexpectedly one morning. Rather, most of these needs can be anticipated and planned for. Accordingly, one could adopt a variety of restrictions on the timing of sales without hindering the executive's ability to satisfy his legitimate liquidity and diversification needs. For example, one could require that sales be carried out gradually over a specified period, perhaps pursuant to a prearranged plan. One could require the executive to receive advance permission from the compensation committee (or another committee) before trading. Or, the executive could be asked to sell the shares directly to the company for the average share price over a specified (and sufficiently long) period (say, the prior six months).

The advantage of preventing managers from controlling the exact timing of their sales is that it would reduce the amount of profits they can make trading on their inside information. Although it is illegal for executives to trade on "material" inside information, the "materiality" standard is sufficiently high that executives can still make significant profits trading on inside information that is valuable but not considered legally "material." These profits are unlikely to be an efficient mechanism for compensating executives. Indeed, the prospect of being able to control the timing of trades and make such profits might not only fail to provide useful incentives to executive, but also distort their be-

192 See Fried, $71 \mathrm{~S} \mathrm{Cal} \mathrm{L} \mathrm{Rev} \mathrm{at} \mathrm{334-37} \mathrm{(cited} \mathrm{in} \mathrm{note} \mathrm{5).} \mathrm{For} \mathrm{more} \mathrm{recent} \mathrm{evidence,} \mathrm{see} \mathrm{Jennifer} \mathrm{N.}$ Carpenter and Barbara Remmers, Executive Stock Option Exercises and Inside Information, $74 \mathrm{~J}$ Bus 513-34 (2001) (finding evidence that senior managers of small publicly traded companies exercise their options and sell the underlying stock shortly before the price of the stock exhibits negative abnormal returns). 
havior in a way that hurts shareholders. ${ }^{193}$ For example, the ability to time their sales might enable managers to benefit from transient rises in the stock price that do not reflect the creation of long-term shareholder value. This, in turn, would undesirably increase managers' focus on short-term price movements.

Surprisingly, however, most firms impose few restrictions on executives' ability to time the unwinding of their incentives. To be sure, in the past fifteen years many firms have adopted trading windows and blackout periods which prevent executives from trading during periods when they are likely to know "material" inside information-for example, a large, unexpected change in quarterly earnings - on which it is illegal to trade. But the impetus for these restrictions came not from a desire to improve pay arrangements but rather from the adoption of tough insider trading laws in the 1980s that made firms liable for illegal insider trading by their employees if they had not taken reasonable steps to prevent such trading. Moreover, these trading windows and blackout periods frequently fail to prevent executives with important but not legally "material" inside information from selling their shares before large stock price declines, thereby avoiding large losses.

Whether or not the board restricts the timing of sales, the board could require enhanced disclosure of these trades. Currently, Section 16(a) of the Securities Exchange Act of 1934 requires that executives disclose their trades to the Securities and Exchange Commission by the tenth day of the month following the trade. Under the optimal contracting approach, one might expect firms to require their executives to provide much earlier disclosure.

For example, the board could, as one of us has proposed in an earlier work, require executives to publicly disclose publicly in advance their intended trades. ${ }^{196}$ Under such a pretrading disclosure scheme, announcement of an unusually large sale would signal the possibility that the executive knows bad news about the firm, driving the price down. The market's reaction would reduce executives' ability to make profits trading on their inside information.

193 See Fried, 71 S Cal L Rev at 313-16 (cited in note 5).

194 Id at 331,345

195 See, for example, Bridget O’Brian, Insider Selling of a Stock Headed South May Mean Others Should Also Bail Out, Wall St J C14 (July 17, 1996) (reporting that an executive of Micro Warehouse Inc., which permits executives to trade only during a nine-day period that begins five days after each quarterly earnings announcement, sold \$2.4 million of stock in late-April/early-May, a month before an announcement about disappointing second quarter earnings drove the share price down by more than 60 percent). For an explanation for why trading windows do not completely prevent executives from trading on inside information, see Fried, $71 \mathrm{~S}$ Cal L Rev at 346 (cited in note 5).

196 See Fried, 71 S Cal L Rev at 348 (cited in note 5). 
Alternatively, the board could require real-time disclosure or disclosure the day after the sale. But even firms that use trading windows or similar restrictions make no attempt to require managers to provide timely disclosure of sales. Indeed, many firms have moved in the opposite direction and taken steps to reduce transparency. These firms permit or even facilitate transactions that are economically equivalent to sales but which allow the executives to avoid making the usual post-trade disclosure to the SEC. For example, more than 25 percent of large companies give their executives multi-million-dollar loans, which executives often repay with company stock. Although the use of stock to repay these loans is economically equivalent to a sale of the stock to shareholders, these transactions are not covered by Section 16(a) and thus need not be reported to the SEC by the tenth day of the following month. Instead, firms are required to disclose these transactions only once per year, within forty-five days of the end of the fiscal year.

Not surprisingly, executives exploit their broad freedom to time their sales of shares and camouflage these transactions to make substantial profits trading on private information. In fact, there is evidence indicating that executives make at least several billion dollars per year in profits (and avoided losses) because of their access to inside information. Although the broad freedom to make such profits is difficult to explain from an optimal contacting perspective, it is easily explained under the managerial power approach. These profits, which ultimately come at the expense of public shareholders, provide extra value to executives that does not show up in any of the firm's accounting information or compensation figures disclosed to shareholders. These insider trading profits are also not usually remarked on by the media, except in notorious cases involving large sales of stock that precede dramatic declines in the stock price. ${ }^{9}$ Thus, the cost of these hidden insider trading profits to shareholders is likely to go unnoticed.

\section{E. Reload Options}

A significant number of firms grant new, or "reload," options to executives who exercise options by surrendering stock. This practice is yet another twist to conventional options plans that we think is better explained by the managerial power approach than by the optimal contract-

197 David Leonhardt, It's Called a 'Loan', But It's Far Sweeter, NY Times $\S 3$ at 1 (Feb 3, 2002).

198 See Fried, $71 \mathrm{~S} \mathrm{Cal} \mathrm{L} \mathrm{Rev} \mathrm{at} \mathrm{332,} 323$ (cited in note 5).

199 For example, the media have recently focused their attention on the fact that Enron executives sold $\$ 1$ billion worth of shares in the period leading up to the firm's bankruptcy, even as the executives were encouraging shareholders and employees to buy the stock. 
ing approach. ${ }^{200}$ Basic reload options work as follows: The holder of an option with a reload provision exercises that option before expiration and pays the exercise price with stock that he already owns. In return, he receives the underlying shares optioned, plus a new option for each share tendered in exercising the options. The new reload options carry the same expiration date as the original options, but the exercise price is set at market. For example, a CEO who held ten reloadable options with a \$20 strike price would surrender five shares of stock to exercise the options if the market price at exercise stood at $\$ 40 /$ share. He would receive the ten shares optioned plus five new reload options with a $\$ 40$ strike price.

Options with a reload provision are worth more to the holder than are conventional options. By exercising the first generation options after a price spike, the recipient locks in a portion of the gain against a subsequent share price decline, and the reload options allow him to do so without giving up all of the upside potential. ${ }^{22}$ Thus, reload options enable executives to profit more from share price volatility - even if longterm share performance is flat. The incremental value of the reload feature depends on the volatility of the firm's stock price and other factors. Examining one executive at one firm by way of example, Saly, Jagannathan and Huddart estimated that basic reload options in that case were worth about 15 percent more than conventional options.

Reloads are difficult to explain under the optimal contracting approach. Proponents argue that the reload feature encourages executives to exercise options earlier and therefore to hold more shares. ${ }^{204}$ However, if the executives sell the shares they receive on exercise, as is generally the case, ${ }^{205}$ the reloads do not result in executives holding more

200 Reingold reports that reload provisions were included in 17 percent of new stock option plans adopted in 1997. See Jennifer Reingold, Nice Option If You Can Get It, Bus Week 111 (May 4, 1998).

201 As will be explained, there are several variations on the reload theme. For example, some reload plans provide additional reload options to replace shares that would have to be sold to pay the tax that is due on exercise.

202 Hemmer and colleagues demonstrate that it is optimal for the holder of a multiple-reload option to exercise whenever the stock price exceeds the previous high reached since the grant date. See Thomas Hemmer, Steve Matsunaga, and Terry Sherlin, Optimal Exercise and the Cost of Granting Employee Stock Options with a Reload Provision, 36 J Acct Rsrch 231, 234 (1998).

203 See P. Jane Saly, Ravi Jagannathan, and Steven J. Huddart, Valuing the Reload Feature of Executive Stock Options, 12 Acct Horizons 219, 220 (1999).

204 See Christopher Gay, Hard to Lose: 'Reload' Options Promote Stock Ownership among Executives; But Critics Say They're a Lot More Costly than Shareholders Realize, Wall St J R6 (Apr 8, 1999); Reingold, Nice Option, Bus Week at 111 (cited in note 200).

205 See Ofek and Yermack, 55 J Fin at 1377-78 (cited in note 183) (examining S\&P 1500 data from the 1993-1995 period and finding that executives with relatively low stock holdings retain about 30 percent of the shares received on exercise of their options, while relatively high ownership executives sold all of their shares). 
shares unless there are additional constraints on the reload program. For example, a reload plan might place minimum holding times on the stock surrendered on exercise or on the stock received through exercise, and thereby indirectly or directly cause executives to hold more stock. However, there is a cheaper and more direct way to achieve the same result: the executive could be required to own a minimum number of shares. In some cases, the reload feature might actually reduce an executive's shareholdings by giving him an incentive to "pay" for his reload options with existing shares rather than with cash raised.

Although reloads are not easily explained by the optimal contracting approach to executive compensation, the reload feature is quite consistent with the managerial power approach. The reload feature makes the options more valuable for the executives, but it does so in a way that is complex and hard to evaluate. Despite their added cost, reloads can plausibly be justified to investors. Even better, reloads can be tweaked to provide even more value with little or no investor reaction. We have already seen that options with the basic reload feature are more valuable to their recipients, and we have suggested that their justificationincreasing executive stock ownership - is facially plausible, but that the benefit is illusory unless the executives are required to hold shares for some period prior to or following option exercise. These are constraints that have little or nothing to do with reloads per se. We will now turn to the variations in reloads that add even more value.

An executive who exercises nonqualified stock options owes ordinary income tax on the gain. Many firms with reload programs issue additional reload options to cover the shares that must be set aside to pay the executive's taxes. ${ }^{206}$ This practice is justified as necessary to maintain the executive's total share price exposure. This sounds plausible at first blush, but in fact the tax reload provision (as it is known) is the equivalent of making a larger conventional option grant in the first place - a grant that is more valuable to the executive and more costly for the shareholders.

206 See Gay, Hard to Lose, Wall St J at R6 (cited in note 204) (reporting that twenty-one of forty reload firms surveyed issue additional options to replace shares set aside to pay taxes on option exercise).

207 See id.

208 Saly and colleagues estimated that, with the tax reload feature, the reload options they studied were worth 24 percent more than conventional options, holding other terms of the options constant. See Saly, Jagannathan, and Huddart, 12 Acct Horizons at 220 (cited in note 203). Without the tax reload feature these reload options would have been worth 15 percent more than conventional options. Id. A few companies deviate from the standard reload design in other ways. Some issue a new option for every option exercised, rather than for each share surrendered in exercising the options. See Gay, Hard to Lose, Wall St J at R6 (cited in note 204) (reporting that three of forty reload firms surveyed used this procedure). Others extend the term of the new options issued beyond the maturity date of the initial options. See id. Both practices add value for executives, and one can imagine, without help from us, the weak but perhaps vaguely plausible 
One might ask, what is so special about the tax that is due on the exercise of options? Most executives own a fair number of shares of company stock and owe taxes each year on their salary, bonus, exercised options, and restricted stock that becomes unrestricted. One could just as plausibly argue that the company should issue options to replace hypothetical stock sales made by an executive to cover the taxes due on any of these sources of income.

\section{F. Gratuitous Acquisition-Related Payments}

Another compensation practice that is more easily explained under the managerial power approach is the practice of giving the CEO of an acquired firm a "gratuitous" payment for facilitating the acquisition-a payment that is not required under the terms of his contract.

It is no secret that executives are often paid large amounts when their firms are acquired. ${ }^{209}$ In many cases, these payments are made pursuant to the terms of the executive's compensation contract. One common way for the compensation contract to provide for an acquisitionrelated payment to the executive is through what is called a "golden parachute." Under such an arrangement, the executive is paid a specified amount in the event that the firm is acquired and certain other conditions are met.

There is a debate over whether the use of golden parachutes and similar arrangements is driven by optimal contracting or managerial opportunism. Some researchers have argued that golden parachutes encourage managers to take desirable risks; others have argued that golden parachutes reduce the disciplining effect on managers of the market for corporate control.

justifications that might be offered in support of these variants.

209 See Jay Hartzell, Eli Ofek, and David Yermack, What's in It for Me?: Personal Benefits Obtained by CEO's Whose Firms Are Acquired at 3, New York University Stern School of Business working paper (2000), available online at $<\mathrm{http} / / /$ www.stern.nyu.edu/ eofek/papers.htm $>$ (visited Apr 27, 2002) (reporting that CEOs whose firms are acquired obtain total financial of gains with a median value of $\$ 4$ to $\$ 5$ million and a mean value of $\$ 8$ to $\$ 11$ million).

210 See id at 11 (reporting that 69 percent of the CEOs in a sample of firms that were acquired had golden parachutes)

211 There is an extensive literature investigating the incentives and wealth transfers created by golden parachutes and other ex ante compensation arrangements. For theoretical and empirical investigations of the effect of golden parachutes on ex ante incentives and wealth, see Albert Choi, Golden Parachute as a Compensation Shifting Mechanism at 6-8, University of Virginia working paper (2002), available online at $<$ http://www.people.virginia.edu/ ahc4p/> (visited May 3, 2002) (presenting a model in which the creation of a golden parachute shifts some of the expected cost of compensating the executive to an acquirer, thereby allowing shareholders to pay the executive a lower salary when there is no acquisition); Lane Daley and Chandra Subramaniam, Free Cash Flow, Golden Parachutes, and the Discipline of Takeover Activity, 27 J Bus Fin \& Acct 1, 3-4 (2000) (presenting evidence that entrenched managers get golden parachutes to shield them from market discipline); M.P. Narayanan and Anant K. Sundaram, A Safe Landing? Golden Parachutes 
Our focus, however, is on situations where executives receive payments in connection with acquisitions that are not required under the terms of the executives' compensation contracts. These gratuitous acquisition payments, which are often made in addition to golden parachute payments, can take a variety of forms. For example, target boards sometimes augment the value of a previously negotiated golden parachute ${ }_{213}$ At other times, target boards make special cash payments to the CEO.

Gratuitous payments, by definition, are not negotiated in advance. Because managers do not know whether they will receive a gratuitous payment if there is an acquisition (and the amount of such payment, if any), the prospect of such a payment is unlikely to have much effectgood or bad-on managerial behavior ex ante. Thus, even if it could be shown conclusively that golden parachutes generate desirable ex ante incentives, it would still be difficult to explain how these gratuitous payments reflect optimal contracting.

However, gratuitous payments can easily be explained under the managerial power approach. That approach suggests two reasons why boards might agree to make these payments. First, given a CEO's power to delay or prevent desirable acquisitions, the board might find it necessary to "bribe" the CEO to allow the acquisition to go forward smoothly. Second, the CEO might be able to convince the board to give him a parting gift (using shareholders' money). In each case, the CEO is using his power to extract rents.

Consider the first situation: the board determines it must bribe the CEO to allow the acquisition to go forward. Managers enjoy private benefits of control (including rent extraction through formal salary ar-

and Corporate Behavior at 3, University of Michigan working paper 98-015R (1998), available online at $<$ http://eres.bus.umich.edu/docs/workpap/wp98_015r.pdf> (visited May 3, 2002) (examining 245 firms adopting golden parachutes for the first time during 1980-1994 and concluding that managers do not appear to run down firms following adoption of golden parachute plans in the hope of being acquired); Charles $\mathrm{R}$. Knoeber, Golden Parachutes, Shark Repellants, and Hostile Tender Offers, 76 Am Econ Rev 155 , 160 (1986) (explaining how golden parachutes can function as bonds posted by shareholders to prevent shareholders from opportunistically reneging on implicit long-term compensation by selling the firm to a new owner); Richard Lambert and David Larcker, Golden Parachutes, Executive Decision-Making, and Shareholder Wealth, 7 J Acct \& Econ 179, 183-86 (1985) (arguing that golden parachutes reduce shareholder value by insulating managers from takeover discipline).

For evidence on how ex ante compensation arrangements affect managers' willingness to allow an acquisition, compare Judith C. Machlin, Hyuk Choe, and James A. Miles, The Effects of Golden Parachutes on Takeover Activity, 36 J L \& Econ 861, 869 (1993) (reporting that golden parachute contracts increase the likelihood of an acquisition), with James F. Cotter and Marc Zenner, How Managerial Wealth Affects the Tender Offer Process, 35 J Fin Econ 63, 92 (1994) (finding no significant effect of golden parachutes on likelihood of acquisition).

212 See id at 12 (reporting that in 12 percent of the cases where the target CEO has a golden parachute the target board increases the payout at the time it approves the merger).

213 See id (reporting that in 27 percent of acquisitions the target board gives the CEO a special cash payment at the time it approves the merger). 
rangements, which is the focus of this Article) because of their positions in the firm. Therefore, they have an incentive to resist takeovers, even if the takeover would benefit shareholders. Under current law, managers have the power to resist a takeover and substantially delay the completion of any acquisition. Given managers' ability to impede the acquisition, it might be necessary to bribe them not to.

To be more concrete, let $B$ denote the (present value of the) private benefits that managers will lose in the event their firm is acquired. Let $G_{\mathrm{a}}$ denote the acquisition-related payment, if any, to which managers are contractually entitled by virtue of a golden parachute or similar ex ante arrangement. Let $G_{\mathrm{p}}$ denote the gratuitous acquisition-related payment. If $G_{\mathrm{a}}<B$, the managers will have an incentive to resist the acquisition unless the board provides the managers with an (additional) payment, $G_{\mathrm{p}}$, such that $G_{\mathrm{a}}+G_{\mathrm{p}}>B$. And, even if $G_{\mathrm{a}}>B$, managers might threaten to hold up the deal unless they receive more compensation.

It may well be the case that, given managers' power to defend their positions and the private benefits of control they enjoy as a result of their positions, it is a desirable "second-best" strategy for boards to reward managers with gratuitous payments for allowing acquisitions to take place. ${ }^{24}$ If so, these arrangements should not be restricted or substantially curtailed. Although such restrictions might make shareholders better off in cases where they do not prevent an acquisition, such restrictions would leave shareholders in a worse position overall by reducing the number of value-increasing acquisitions. ${ }^{215}$ For our purposes, however, it is irrelevant whether the practice of giving CEOs gratuitous payments to facilitate transactions is desirable. The important point, for our purposes, is that the practice of making such payments is an indication that managers use their power to extract rents.

The second reason a board might give a CEO a gratuitous payment in connection with an acquisition is to bestow a gift on the CEO. That is, the payment is not necessary to secure the CEO's cooperation in connection with the acquisition. The board might agree to make this pay-

214 See Kahan and Rock, 69 U Chi L Rev at 898 (cited in note 86). For a systematic analysis of the effects of managerial compensation on managers' incentives to facilitate and bargain over acquisitions, see Ehud Kamar, Managerial Change-in-Control Benefits and Takeovers, working paper (2002) (on file with authors).

215 But see Hartzell, Ofek, and Yermack, What's in It for Me? at 20 (cited in note 209) (finding evidence that in transactions where CEOs get direct or indirect gratuitous transfers, they negotiate lower acquisition premia for shareholders). For evidence of the effect of ex ante compensation agreements on the likelihood of acquisition, compare Machlin, Choe, and Miles, 36 J L \& Econ at 869 (cited in note 211) (reporting that golden parachute contracts increase the likelihood of an acquisition), with Cotter and Zenner, $35 \mathrm{~J}$ Fin Econ at 92 (cited in note 211) (finding no significant effect of golden parachutes on likelihood of acquisition). 
ment out of affection for the CEO, because of personal gratitude, or to curry favor with the CEO (who might be in a position to help them in the future). This payment, made with shareholders' money, provides no benefit to shareholders - unlike the bribe in the first situation.

There are a number of reasons why an acquisition might facilitate the extraction of these additional rents. The acquisition might enable such rent-extraction because the CEO and the board need not fear any repercussions from shareholders. Alternatively, the acquisition might provide camouflage by distracting shareholders from the payment or tying the payment to a transaction that benefits shareholders overall. In any event, the gift reflects managers' use of power-specifically, their close relationship with the board-to extract rents.

\section{G. Differences between Executives with More and Less Power}

The managerial power approach focuses upon the connection between managerial power and the rents that managers can extract. In all companies with dispersed shareholders and no controlling shareholder, executives will have power and will be able to extract at least some rents. Management power, however, is not uniform in all companies with dispersed shareholding. Managers will have more or less power depending upon the presence of effective takeover impediments, the structure of the board, the presence of large shareholders (even if they are not controlling shareholders), and the fraction of shares held by institutional investors. All else being equal, the managerial power approach predicts that managers will extract more rents in situations and structures in which they have more power. There is substantial evidence consistent with this position.

\section{Relationship between power and pay.}

There are several factors whose presence would tend to make managers more powerful. Other things being equal, managers would tend to have more power when (a) the managers are protected by antitakeover arrangements, (b) the board is relatively weak or ineffectual, (c) the managers have a large ownership stake, (d) there are fewer institutional shareholders, or (e) there is no large outside shareholder. As described below, empirical examinations of each of these factors have found that they affect managerial pay arrangements in the way predicted by the managerial power approach.

(a) Antitakeover protection. There is evidence that CEOs of firms that adopt antitakeover provisions get higher salaries, receive more op- 
tions, and are more likely to have a golden parachute arrangement. ${ }^{216}$ The mean level of above-market compensation increases significantly after the provisions are adopted-that is, after the CEOs have become less vulnerable to a hostile takeover.

(b) Strength and independence of boards. In addition, there is evidence that executive compensation is higher when the CEO is more powerful vis-à-vis the board. Core, Holthausen, and Larcker find that CEO compensation is higher when the board is larger (and thus less cohesive), when more of the outside directors have been appointed by the CEO (and thus might feel a sense of gratitude and obligation to the CEO), when the outside directors are older, and when outsiders serve on five or more boards (and thus are likely to be relatively distracted). Cyert, et al, report that CEO pay is negatively related to the share ownership of the board of directors, is positively related to the CEO's tenure, and is higher if the CEO is the chairman of the board. ${ }^{219}$ Relatedly,

216 See Kenneth A. Borokhovich, Kelly R. Brunarski, and Robert Parrino, CEO Contracting and AntiTakeover Amendments, 52 J Fin 1495, 1503-13 (1997). Optimal contracting might predict the opposite- that if managers' jobs are more secure, shareholders need not pay managers as high a risk premium. See Anup Agrawal and Charles R. Knoeber, Managerial Compensation and the Threat of Takeover, $47 \mathrm{~J}$ Fin Econ 219 (1998) (finding that CEOs of firms in industries with a higher rate of takeovers and CEOs of firms that are eventually taken over are paid slightly more than other CEOs, and attributing this differential to a riskpremium paid to CEOs more likely to lose their jobs).

217 See Borokhovich, Brunarski, and Parrino, 52 J Fin at 1515 (cited in note 216). Managers who have become less vulnerable to a hostile takeover take advantage of their power in other ways as well. For example, CEOs of firms incorporated in states that adopt antitakeover statutes reduce their use of debt in order to reduce the risk of financial distress and constraints on their use of the firms' cash, even though the debt is likely to have provided useful tax and agency benefits. See Gerald T. Garvey and Gordon Hanka, Capital Structure and Corporate Control: The Effect of Antitakeover Statutes on Firm Leverage, 54 J Fin 519, 521 (1999) (finding that, overall, impediments to takeovers induce a shift from debt to equity financing). See also Shjun Cheng, Venky Nagar, and Madhar V. Rajan, Control versus Risk in Stock-Based Incentives: Evidence from Antitakeover Regulation at 30, working paper (2001), available online at $<$ http://papers.ssrn.com/id=288738> (visited May 3, 2002) (finding that CEOs of firms that become protected by new takeover legislation sell a large portion of their shares because the shares are not as necessary for maintaining control).

218 See John E. Core, Robert W. Holthausen, and David E. Larcker, Corporate Governance, Chief Executive Compensation, and Firm Performance, 51 J Fin Econ 371, 372-73 (1999). CEO pay also increases when a board contains interlocking directors. See Kevin Hallock, Reciprocally Interlocking Boards of Directors and Executive Compensation, 32 J Fin \& Quant Anal 331, 332 (1997) (finding that the pay gap between interlocked and non-interlocked firms is as high as 17 percent after adjusting for all variables). This might not be as rare as one would imagine: in approximately one out of twelve firms, the board is current CEOinterlocked: the CEO of Firm A sits on the board of Firm B, and the CEO of Firm B sits on the board of Firm A. See Kevin Hallock, Dual Agency: Corporate Boards with Reciprocally Interlocking Relationships, in Jennifer Carpenter and David Yermack, eds, Executive Compensation and Shareholder Value: Theory and Evidence 55, 58 (Kluwer Academic 1999) (reporting that 8 percent of a sample of 773 large publicly-traded firms had CEO-interlocked boards and 12 percent had employee-interlocked boards). For an examination of the factors that make reciprocal CEO board membership more likely, see Eliezer M. Fich and Lawrence J White, Why Do CEO's Reciprocally Sit on Each Other's Boards? at 1-3, working paper (2001), available online at $<\mathrm{http}: / / \mathrm{www}$.stern.nyu.edu/clb/01-002.pdf $>$ (visited Apr 27, 2002).

219 See Cyert, et al, Corporate Governance at 17-20 (cited in note 37). They also find that CEO pay is 
Wade, O'Reilly, and Chandratat find that as the percentage of the board composed of outsiders appointed after the CEO takes office increases, the more likely it is that the CEO will be able to secure a golden parachute.

(c) CEO share ownership. The managerial power approach predicts that as the CEO's share ownership increases, thereby making the CEO more powerful vis-à-vis other shareholders, his compensation will increase. In fact, the amount of CEO compensation is positively related to CEO stock ownership. ${ }^{221}$ Not surprisingly, executives owning majority blocks receive higher salaries than executives in similar firms that do not have a lock on control.

(d) Presence of institutional investors. In a study of S\&P firms from 1991 through 1997, Hartzell and Starks find that the more concentrated institutional ownership is, the lower executive compensation is. They also find that a larger institutional presence results in more performancesensitive compensation. ${ }^{22}$ This study suggests that the presence of institutions serves to reduce the power of management to extract rents through compensation.

(e) Presence of a large blockholder. Moreover, there is evidence that the presence of a large shareholder is significant. Even when such a shareholder does not have a controlling or dominant position, its monitoring can reduce the extraction of rents. Richard Cyert and his colleagues found a negative relationship between the equity ownership of the largest shareholder and the amount of CEO compensation. ${ }^{24}$ In an analysis of manufacturing firms, Tosi and Gomez-Mejia determined that CEO incentive alignment is superior, and that the CEO exercises less in-

positively related to the percentage of outsiders on the board. They surmise that many of the outside directors are handpicked friends of the CEO.

220 See James Wade, Charles A. O'Reilly, III, and Ike Chandratat, Golden Parachutes, CEOs and the Exercise of Social Influence, 35 Admin Sci Q 587, 592-93 (1990) There is also evidence that the structure of CEO pay is affected by the composition of the compensation committee. When at least one member of the compensation committee is an insider, the sensitivity of pay to performance is lower. See Harry A. Newman and Haim A. Mozes, Does the Composition of the Compensation Committee Influence CEO Compensation Practices?, 28 Fin Mgmt 41-53 (1999).

221 See Cyert, et al, Corporate Governance at 3 (cited in note 37).

222 Clifford Holderness and Dennis Sheehan, The Role of Majority Shareholders in Publicly Held Corporations, 20 J Fin Econ 317 (1988) (finding that top executives owning majority blocks receive larger salaries than top executives in similar firms in which shareholding is diffuse).

223 See Jay C. Hartzell and Laura T. Starks, Institutional Investors and Executive Compensation at 32, working paper (2002), available online at <http://www.bus.utexas.edu/AIMCenter/ Working\%20Papers/Hartzell8.pdf> (visited Apr 27, 2002) (finding a significant negative relationship between CEO compensation and the concentration of institutional ownership).

224 See Cyert, et al, Corporate Governance at 18 (cited in note 37) (finding that a CEO who is not also the largest shareholder receives, on average, about 5 percent less in total compensation). 
fluence over his own compensation, when the company has a 5-percent external shareholder.

In two recent creative empirical studies, Bertrand and Mullainathan present findings indicating that the absence of shareholders owning more than 5 percent of the shares is associated with significant deviations from optimal contracting. In the first study, Bertrand and Mullainathan examine companies with and without a large shareholder to determine if there is a difference in the extent to which CEOs are rewarded for changes in company performance outside of their control (in other words, for luck). ${ }^{226}$ The study finds that CEOs in firms that lacked large external shareholders tended to receive more "luck-based" pay. Furthermore, this study finds that CEOs in firms that lack large shareholders have their cash compensation reduced less when their options-based compensation is increased.

The second study by Bertrand and Mullainathan compares companies with and without a 5-percent shareholder in terms of how the performance sensitivity of compensation relates to the volatility of the company's stock price. ${ }^{28}$ Under optimal contracting, pay-performance sensitivity should decrease with increasing variance. However, the study finds that such a relationship is present only among companies that have a 5-percent outside shareholder.

\section{Inferences and objections.}

From the various empirical studies described above, there emerges a clear picture of a link between managerial power and pay arrangements - a link that is predicted by the managerial power approach. Interestingly, the financial economists who conducted the above studies, unlike most academics working in this area, came to the view that some appropriation of wealth might be taking place in those situations in which managers are especially powerful. Bertrand and Mullainathan, for example, concluded that some "skimming" takes place in companies

\footnotetext{
225 See Henry L. Tosi Jr. and Luis R. Gomez-Mejia, The Decoupling of CEO Pay and Performance: An Agency Theory Perspective, 34 Admin Sci Q 169, 181 (1989). Relatedly, Benz, Kucher, and Stutzer find that in S\&P 500 firms a higher concentration of shareholders results in a significantly reduced number of options granted to top executives. See Matthias Benz, Marcel Kucher, and Alois Stutzer, Stock Options: The Managers'Blessing: Institutional Restrictions and Executive Compensation at 21, University of Zurich Institute for Empirical Research in Economics Working Paper No 61 (2001), available online at $<$ http://www.iew.unizh.ch/wp/iewwp061.pdf > (visited Apr 8, 2002).

226 See Marianne Bertrand and Sendhil Mullainathan, Are CEOs Rewarded for Luck?: The Ones without Principals Are, 116 Q J Econ 901, 929 (2001).

227 See Bertrand and Mullainathan, Do CEO's Set Their Own Pay? at 34 (cited in note 158).

228 See Marianne Bertrand and Sendhil Mullainathan, Agents with and without Principals, 90 Am Econ Assoc Papers \& Proceedings 203 (2000).
} 
without a 5-percent shareholder. ${ }^{229}$ However, these researchers appear to believe that rent extraction occurs only in situations in which managers are relatively more powerful.

In our view, once the connection between power and rents is recognized, there is reason to believe that managerial rent extraction might occur to some extent in all companies without a controlling or dominant shareholder. To be sure, managers will have less power, and thus be able to extract less rents, in circumstances in which a large external shareholder is present or more shares are in the hands of institutions. As we have explained, however, even in such circumstances managers still have considerable power and thus can be expected to extract rents. Indeed, the compensation practices we have described in the preceding sections of Part III (such as the absence of reduced-windfall options and the lack of unwinding restrictions) occur also at companies which have large shareholders or concentrated institutional share ownership. This indicates that rent extraction might well take place, even if to a reduced extent, in companies where managers are less powerful.

Finally, we wish to discuss the recent finding Kevin Murphy has put forward as evidence inconsistent with our managerial power approach. Murphy provides evidence that newly hired CEOs coming from outside of the firm receive in their first year almost twice the total compensation of newly hired CEOs coming from inside the firm. Suggesting that CEOs coming from outside of the firm do not yet have power to influence their pay, Murphy argues that their higher pay is inconsistent with the managerial power hypothesis.

We think that such an inference cannot be drawn. To begin with, while the managerial power approach suggests that managers with more power are paid more, all else being equal, it does not suggest that more power is the only reason why some managers are paid more than others. Inside candidates usually have an advantage over outsiders because of their familiarity with the firm and their existing ties to the board. Thus,

229 See id at 205.

230 Consider cases in which a 5- or 10-percent external shareholder is present. Given the power that managers have to issue poison pills and to control the proxy machinery, such a shareholder might have influence but usually not anything close to controlling power. Thus, executives in such cases are likely to have still a great deal of power.

231 See Murphy, 69 U Chi L Rev at 853 (cited in note 141).

232 It is not clear that the boards' bargaining with a soon-to-be-hired CEO is arm's length bargaining. The directors will recognize that the person on the other side will in the future have influence over director nominations and compensation. If one of us had the chance to bargain with his soon-to-be hired dean over the dean's compensation terms, we doubt that the bargaining would be at arm's length. In any event, the critical point for Murphy's argument, and one with which we agree, is that while bargaining with soon-to-behired CEOs might differ from arm's length bargaining, soon-to-be-hired CEOs coming from outside should not be expected to have more power than those coming from inside. 
in those instances in which the board turns to the outsiders, the outside hires are likely to be, on average, a stronger group. Furthermore, outside hires are often CEOs already (which inside candidates by definition are not), and thus have higher reservation values.

Indeed, for those outside hires who are already CEOs, the managerial power approach would predict higher pay, even assuming hypothetically (and, we believe, counterfactually) that they were not a stronger group on average than inside hires. CEOs hired from the outside who at the time of their hiring are CEOs of other firms are likely to be using their power at those firms to extract rents. Thus, the hiring firm cannot attract them without compensating them for whatever rents they currently enjoy and must give up to take the new positions. In contrast, no such compensation need be given when the company can find and hire an appropriate candidate in-house because that in-house candidate does not give up the rents and private benefits associated with being a CEO in order to take the CEO position.

\section{H. Differences between U.S. and Non-U.S. Companies}

$\mathrm{U}_{23} \mathrm{~S}$. CEOs are paid considerably more than their non-U.S. counterparts, ${ }^{23}$ but lower-level managers are not. U.S. CEOs receive both more option- and equity-based pay ${ }^{234}$ and more cash compensation than their non-U.S. counterparts. ${ }^{235}$ U.S. human resources directors, by comparison, receive no more compensation than their international counterparts. $^{236}$ The U.S./international CEO pay gap provides yet another puzzle for students of executive compensation to explain.

Can the optimal contracting approach provide a persuasive explanation for this pattern? First, it might be argued that U.S. CEOs are simply more important to the success of the business. The skills of the CEO might be more important in the U.S. if our corporate culture gives CEOs more decisionmaking power than others. Undoubtedly, the CEO is the major factor in the success of many U.S. companies. However, there is

\footnotetext{
233 See Abowd and Bognanno, International Differences at 70-72 (cited in note 58); Murphy, Executive Compensation at 7 (cited in note 2).

234 See Abowd and Bognanno, International Differences at 70-72 (cited in note 58); Murphy, Executive Compensation at 7 (cited in note 2).

235 See Mark J. Lowenstein, The Conundrum of Executive Compensation, 35 Wake Forest L Rev 1, 5 (2000).

236 See Abowd and Bognanno, International Differences at 72-73 (cited in note 58).

237 See Murphy, Executive Compensation at 7-9 (cited in note 2), for a thorough review of the puzzle posed by cross-country differences in CEO compensation. For a discussion of whether the differences between U.S. and foreign executive pay practices are likely to be narrowed, see Brian R. Cheffins and Randall S. Thomas, The Globalization (Americanization) of Executive Pay: Yes, No, or Not Yet?, working paper (2002), available online at $\quad<$ http://www.ciaonet.org conf/cip01/cip01c.pdf $>$ (visited May 4, 2002).
} 
no reason to think that CEOs are, on average, less of a factor in the success of many foreign companies. CEOs might also be more important in the U.S. because markets in the U.S. are more competitive and therefore more "demanding," which makes a CEO's skills more critical to the company's performance. In economies with much government regulation and intervention, however, a company's performance might also depend critically on the skills of the CEO (though, in this case, on different skills) in dealing with political and regulatory constraints.

Second, it could be argued that in the U.S. CEOs are relatively scarce. However, the scarcity argument is also not persuasive. Although U.S. firms employ a particularly large number of CEOs, they employ an even larger number of junior executives. It is unclear why qualified CEOs would be relatively more scarce than qualified junior executives.

Third, it might be that the tournament model of executive compensation is more applicable in the U.S. than it is in other countries. According to this theory of compensation, junior executives accept lower pay in their present jobs in exchange for the chance of winning the tournament, becoming CEO, and capturing the big prize. ${ }^{238}$ It is possible that this extremely competitive, survival-of-the-fittest model simply works better in our highly laissez-faire corporate culture than it does abroad. There are theoretical problems with the tournament explanation, ${ }^{239}$ however, and there is no real evidence that it applies to executive pay.

Fourth, it might be argued that U.S. firms are at the front of the learning curve when it comes to CEO pay. It has been suggested that other countries have not caught up to the U.S. with regard to stockbased compensation. ${ }^{240}$ However, the typical CEO in over half of the foreign countries surveyed by Towers Perrin in 1997 did receive options or other long-term performance units; they simply received fewer. Moreover, the learning curve hypothesis fails to explain why U.S. CEOs are better paid than their foreign counterparts but junior executives in the U.S are not.

While the pattern of cross-country differences is difficult to explain under the optimal contracting approach, the managerial power approach can make sense of it. As we have discussed, rent extraction depends on

238 See Edward P. Lazear and Sherwin Rosen, Rank-Order Tournaments as Optimum Labor Contracts, 89 J Polit Econ 841, 841-42 (1981).

239 For example, tournaments might provide poor incentives when it is apparent that one player is likely to win and others likely to lose the competition (due to differences in skills or other qualities) or even encourage collusion or sabotage. See Ronald A. Dye, The Trouble with Tournaments, 22 Econ Inq 147, 148 (1984).

240 See Abowd and Bognanno, International Differences at 70 (cited in note 58).

241 See Murphy, Executive Compensation at 7 (cited in note 2). 
managers having power. In the U.S., managers have considerable power, especially, as we have seen, when ownership is very dispersed and there is no large shareholder to provide discipline. U.S. CEOs rarely have other business interests that could enable them to extract rents through favorable contractual arrangements. Thus, U.S. managers use their power to extract rents through their executive compensation.

In other countries, there are relatively fewer companies with dispersed ownership and relatively more companies with controlling shareholders. ${ }^{242}$ And in those countries with dispersed ownership, such as the United Kingdom, ownership tends to be much more concentrated than in the U.S. ${ }^{243}$ When share ownership is more concentrated, the CEO will have less power (unless, in firms with a controlling shareholder, the CEO is related to the controlling shareholder). Professional CEOs hired by companies with more concentrated ownership and companies controlled by a large shareholder will therefore extract less rents than the CEOs of U.S. firms, whose shareholders are likely to be more dispersed and therefore less able to closely monitor the CEOs.

In some companies controlled by a large shareholder or family, however, those controlling the firm will not hire professional managers but rather install themselves in those positions. CEOs of these companies might well have more power than U.S. CEOs. And they could use this power to extract rents through their executive compensation. But the controlling group or family is likely to control other significant assets that might often offer more important avenues for extracting rentsnamely, through self-dealing and the taking of business opportunities.

In such a case, although the CEO could extract additional rents through executive compensation, refraining from doing so might be a cost-effective means of camouflaging the overall amount of rents that is being extracted. By paying himself reasonable compensation, the controlling shareholder might be able to create the impression that he is be-

242 See Rafael LaPorta, Florencio Lopez-de-Silanes, and Andrei Shleifer, Corporate Ownership around the World, 54 J Fin 471, 491-96 (1999).

243 In Britain, it is common for a firm's twenty-five largest institutional investors to own a majority of the shares. In the U.S. the same number of institutions will typically own only about one-third of the equity. Not surprisingly, U.S. CEOs are much better paid than their British counterparts. See Martin J. Conyon and Kevin J. Murphy, The Prince and the Pauper?: CEO Pay in the United States and the United Kingdom, 110 Econ J 640, 640 (2000). In addition, the options received by British CEOs are more likely to be subject to performance conditions, less likely to have a reload feature, and less likely to be repriced. See correspondence with Professor Brian Cheffins (on file with authors). However, as in the U.S., there are still complaints about the high pay of U.K. CEOs. See Brian R. Cheffins, Company Law: Theory, Structure and Operation 653-706 (Clarendon 1997).

244 See Lucian A. Bebchuk, Reinier H. Kraakman, and George G. Triantis, Stock Pyramids, CrossOwnership, and Dual Class Equity: The Creation and Agency Costs of Separating Control From Cash Flow Rights, in Randall K. Morck, ed, Concentrated Corporate Ownership 295 (Chicago 2000). 
ing loyal to minority shareholders. And because compensation is not that large a source of rents relative to the other sources that are avail-

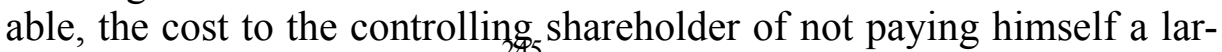
ger salary is relatively small. ${ }^{245}$ In sum, CEO pay tends to be lower in other countries because the CEO either has less power to extract rents or the CEO generally has other avenues for rent extraction (because the CEO is affiliated with the controller, who is likely to have other business interests).

The managerial power approach is consistent with the observation that the cross-country difference in pay is concentrated at the top, while much lower-level U.S. executives do not receive more pay than their foreign counterparts. We have noted that sometimes power will be concentrated in the hands of the CEO, and at other times it will be shared by two or more top officers. As a result, rents will be received either by the CEO or the CEO and one or more other top-ranking executives. This would suggest that at times there will be a compensation differential only at the CEO level, and at other times there will be such a differential with respect to the CEO and one or two other top executives. Thus, it is not surprising that human resources directors and other lower-level executives who do not have a significant share of corporate power do not enjoy higher compensation than their non-U.S. peers. ${ }^{246}$ The managerial power explanation that we have put forward here is also consistent with our explanation of the finding that, in the U.S., CEOs of companies that have large shareholders are paid less than CEOs of companies that do not.

\section{CONCLUSION}

This Article has examined two alternative approaches to the study and analysis of executive compensation: the optimal contracting approach, which has dominated academic research on the subject, and the managerial power approach, which focuses on the role of managerial power in explaining deviations from optimal contracting. The former approach views executive compensation as an instrument for combating the agency problem between managers and dispersed shareholders; the latter approach regards compensation arrangements as partly a product of the agency problem.

\footnotetext{
245 In some countries, minority shareholder rights are so weak that there is no need for the controlling shareholder to camouflage rent extraction. This might explain why in some emerging markets executive compensation in family controlled firms is so high.

246 It would be interesting to compare international pay difference between COOs, CFOs, and other very senior executives who might realistically share power with a CEO.
} 
Analyzing the processes that set executive compensation, we have identified reasons to believe that their outcomes might well deviate significantly from optimal contracting. Whatever the appearances, executive compensation is not generally the product of arm's length bargaining, but is the result of a process that executives can substantially influence. Moreover, although executive compensation is set against a background of market forces, these forces are hardly strong enough to compel optimal contracting outcomes. As a result, executives can use their power to influence compensation arrangements and to extract rent.

The forces that limit rent extraction are affected by how compensation arrangements are perceived by outsiders. This, in turn, provides incentives for structuring compensation arrangements in a way that camouflages the presence and extent of rent extraction. Consequently, the desire to extract rents might lead to the use of inefficient pay structures and produce suboptimal incentives.

Analyzing the large body of empirical evidence on executive compensation, we have concluded that the evidence supports the view that managerial power plays a significant role. Indeed, this approach can explain various puzzling features and practices that have long occupied researchers operating under the optimal contracting approach. Among other things, this approach can explain the conventional use of options that make no attempt to filter out rewards for general market or sector factors, the almost uniform use of at-the-money options, the broad freedom given to executive to unwind incentives and to choose the time of unwinding, and the systematic correlation between managerial power and pay.

The role that managerial power plays in executive compensation has implications for the study, practice, and regulation of corporate governance. For these implications to receive the attention they deserve, the role of managerial power must first be recognized and appreciated. We hope that this Article will contribute to such recognition and that it will provide a useful framework for subsequent study of how managerial power influences executive compensation. 